\title{
BOSCOS I DEVESES A LA CORONA CATALANO-ARAGONESA (S. XIV-XV)
}

\begin{abstract}
SUMARI
Introducció.- I. Els perills de destrucció dels boscos: 1. Obtenció de cendres.- 2. Obtenció d'artigues.- 3. Incendis provocats per pastors i agricultors.II. L'explotació dels boscos: 4. Obtenció de carbó.- 5. Obtenció de llenya per a ús domèstic. Catalunya. País Valencià. Aragó.- 6. Els forns.- 7. La construcció de cases.- 8. La construcció naval.- 9. Altres usos.- 10. Comerç interior i exportació de fusta.- 11. Transport de la fusta. Transport fluvial: l'Ebre i els seus afluents. El Guadalaviar. El Xúquer. Transport terrestre.- III. Les deveses. L'usdefruit controlat de la natura: Catalunya. País Valencià. Aragó.
\end{abstract}

\section{INTRODUCCIÓ}

Els arbres i els boscos gaudien d'una gran consideració a l'Edat Mitjana perquè fornien elements essencials per a la vida de l'home; alguns arbres del bosc oferien glans, nous, castanyes, serves, lledons etc.; d'altres proporcionaven llenya i carbó per a escalfar-se, per a cuinar i per a realitzar diverses activitats artesanals $i$ industrials, fusta per a la construcció de cases i de vaixells, per al mobiliari i per a tota mena d'estris. El sotabosc oferia herbes per als ramats i hàbitat per a la caça'.

1 Després de la publicació de l'obra de T. SCLAFERT, Cultures en Haute-Provence. Déboisement et páturages an Moyen Age, París, SEVPEN, 1959, excel-lent $\mathrm{i}$ molt útil per a nosaltres pel fet que estudia un territori pròxim i similar al nostre per raons de clima, vegetació etc., en la qual donava gran importancia a l'estudi dels boscos, des de fa uns quants anys hi ha hagut força interès per aquest tema; en són una mostra diversos col·loquis, números especials de revistes etc. Entre els treballs més interesants per a l'época medieval cf. R. ROMANO, Histoire des forêts et bistoire économique, «Actes du Colloque sur la fôret» (Besançon, 1966), París, Les Belles Lettres, 1967, pp. 59-65; M. REY, La foret de Chasx as Moyen Ase. Etude de contacts, ibidem, pp. 67-85; R. GIBERT Y SANCHEZ DE LA VEGA, Ordenanzas reales de montes en Castilla (1496-1803), «Actas del II Symposium Historia de la Administración, Madrid, Instituto de Estudios Administrativos, 1971, pp. 307-348; D. MORENO, Storia e arcbeologia fonestale. Una premessa, «Quaderni Storici», 49. Boschi: storia e archeologia (1982), Pp. 7-15; O. RACKMAN, Boscbi e storia dei sistemi silvo-pastorali in Ingbilterra, ibidem, pp. 16-48; H. BRESC, "Disfari et perdiri li fructi et li aglandis: Economie e risorse boschive nella Sicilia medievale (XIII-XV secolo), ibidem, 54 (1983), pp. 941-961; M. COUTEAUX, Déboisement d'altitude par les cbarbonniers de l'Oisans: contribution pollenanalytique, «108 Congrés National des Societés Savantes» (Grenoble, 1983). Economie et Sociétés dans le Dauphiné médiéval, pp. 69-87; J. BOYER, Le commerce des bois de cbarpente et menuiserie à Aix-en-Provence aux XVe, XVle et XVIle siècles, ibidem, Pp. 121-138; P. DUPARC, La montagne d'Auferand. Cinq cent cinquante ans de communauté pastorale, ibidem, Pp. 161-181; E. de BALLE, Aproximació a la bistòria del bosc a la Garrotxa, «Annals», I (Olot, 1986), pp. 17-41; Ch. RENDU, 
Pel fet que servia per a la construcció naval, la fusta es convertí en un producte estratègic i per tant la tallada d'arbres, el transport i sobretot l'exportació foren controlats, especialment perquè la fusta no anés a països musulmans i servís per a reforçar llur marina.

Hom era conscient que un arbre trigava molt a créixer $i$, per tant, les autoritats vetllaven perquè les tallades fossin selectives i mesurades i no destruïssin els boscos. L'any 1290 el rei Alfons el Franc manà al justícia d'Alzira que investigués la tala d'arbres feta en el lloc de Cotes, al País Valencià, i que procedís contra els autors del fet $\mathrm{i}$ els complices ${ }^{2}$. Tallar segons quins arbres $\mathrm{i}$ segons a quins indrets requeria una llicència especial: generalment el rei concedia llicències limitades a un cert nombre d'exemplars, que les autoritats locals havien de verificar $i$ anar anotant al dors de la concessió a mesura que eren tallats, per tal que hom no sobrepassés la quantitat atorgada. Per exemple, l'any 1316 Jaume II concedí a l'orde dels predicadors de la localitat navarresa de Sangüesa autorització per a tallar cent pins en els boscos d'Hecho, destinats a la construcció de llur convent'; un secretari reial, Guillem Ponç, aconseguí una llicència, l'any 1384, per a tallar quaranta arbres als boscos de Torroella de Montgrí $i$ hagué de demanar una confirmació d'aquesta concessió, l'any 1389, perquè mentrestant Joan I havia prohibit tallar cap arbre del bosc reial de Torroella'.

L'any 1402 el rei Martí l'Humà concedí també al seu conseller Ramon de Perellós, vescomte de Roda, una llicència per a tallar mil arbres a la vall de Conat, situada a la Cerdanya, i fer-ne el que volgués' i l'any 1409, en concedí una altra al seu coper Pedro de Sessé per a fer tallar i treure de la vila de Segura, que pertanyia al comtat de Luna, cent metrades de «cuba de roure» i cinquanta «lomeras» i a més cinquanta dotzenes de bigues de $\mathbf{p i}^{6}$.

Quan els monarques volien fusta per a ús de la cort o de les obres que projectaven, també s'esforçaven a ésser precisos en el nombre d'arbres que podien ésser tallats. L'any 1397 el rei Martí ordenà tallar dos lledoners en els termes dels llocs aragonesos de la Cuba i Azuara; havien de servir per a fer escudelles i talladors

\footnotetext{
Quelques jalons pour une bistoire des forets en Condagne: le massif d'Osseja entre 1030 et 1430, Etudes Roussillonnaises offertes à Pierre Ponsich, Perpinyà, Le Publicateur, 1987, pp. 245-251. E. ROVEDA, I boscbi nella pianura lombarda del Quattracento, «Studi Storiciw, 30 (1989), Pp. 1013-1030; M. ARNOUX, Percoption ot exploitation d'un espace forestier: la forêt de Bretewil (Xle-XVe siòcles), «Medievales, langue, textes, histoirew, 18 (1990), pp. 17-32. Les obres generals, com la famosa de G. DUBY, L'économie rurale es la vie des campagmes en l'Ocrident médiéval, Paris, 1962, traducció castellana: Economía rural y vida campesina en el Occidente medieval, ed. Península, 1968, s'han ocupat tambe dels boscos i del seu aprofitament (pp. 190-202). Cf. tambe els congressos: Africolisura e trasformazione dell'ambiense, secoli XIII-XVIII, «Atti delle Settimane di studio e altri convegniw, 11 (1979) Istituto Internazionale di Storia economica «F. Datiniw, Prato, Le Monnier, 1984, i L'ambiente vegetale noll'alto Mediorvo, «Settimane di Studio, sull'alto Medioevow, XXXVII (1989), Spoleto, 1990.

2 R. GALLOFRÉ, Documentos del reinado de Affonso III de Aragón melativos al antigno Reino de Valencia y contenidas en las nogistros de la Coroma de Aragón, Valencia, Institución Alfonso el Magnánimo, 1968, doc. 1659. Uns anys abans sembla que també havia ordenat una investigació sobre els danys i tales fetes pel noble Artal d'Alagó a Vilafamés: ibfdem, doc. 140.

3 ACA, C, reg. 213 , f. 245 r. (1316, novembre, 16).

4 ACA, C, reg. 1871, f. 142 r.-v. (1389, febrer, 24).Comentem més extensament aquest cas a l'apartat sobre la construcció.

S ACA, C, reg. 2047, f. 105 r. (1402, mars, 27).

6 ACA, C, reg. 2206, f. 154 v. (1409, maig, 29).
} 
per a la seva cort $i$ havien d'ésser escollits per dos homes, que el mateix rei designà, que en podien tallar algun altre si els semblava que calia; el preu dels arbres havia d'ésser fixat per dos prohoms elegits per aquests dos homes i pels propietaris'.

El lledoner no era pas un arbre tan abundant, ni de bon tros, com el pi i només era tallat per a una finalitat molt específica, que no exigia una gran quantitat de fusta. Amb els pins hom obria més la mà, tant perquè n'hi havia molts més com perquè eren indispensables per a la construcció; però, així $\mathrm{i}$ tot, hom procurava fixar-ne una quantitat determinada en cada tallada. Així, per exemple, l'any 1406 el rei Martí n'autoritzà una de mil pins a la pineda del terme de Terol i d'uns altres mil a Villel per a un monestir que volia construir a Barcelona; preveient potser, queixes d'ambdues poblacions, ho justificà en el fet que llavors entrava poca fusta procedent de Castella o al menys no tanta com en altres temps ${ }^{a}$.

Tallar un arbre, propietat d'una altra persona, era un delicte greu, especialment en zones poc boscoses. A les comarques meridionals del País Valencià, a Oriola, per exemple, les esmenes de l'any 1307 als furs locals preveien un càstig sever per als qui tallessin arbres: la pèrdua del puny dret. A Montbui, l'any 1296, uns homes acusats de tallar arbres d'un veí foren empresonats, cosa que ocasionà un conflicte greu entre el bisbe de Barcelona, propietari del lloc, i el veguer del Vallès, no pas pel delicte sinó per l'ús de la jurisdicción ${ }^{10}$.

A Oriola, la protecció a l'arbre arribava fins al punt de prohibir que els propietaris els tallessin; és el que disposà el Consell d'Oriola l'any 1408 pel que feia als pins, que podien ésser podats, però no tallats". Oriola era un cas extrem, per l'escassetat d'arbres a la qual ens hem referit però, com veurem, l'interès per preservar la riquesa arbòria fou força general, fins i tot a les terres que, com Catalunya, tenien zones extenses de boscos, especialment a les comarques pirenenques i a les diòcesis de Girona i Barcelona, o com Aragó, que en tenia als Pirineus i a la comarca d'Albarrasí, o com el País Valencià, en diferents indrets.

Malgrat aquesta abundància, la sobreexplotació dels recursos forestals per a diverses activitats podia portar a la depauperació i anihilació del bosc. Com veurem, els monarques se'n preocuparen sovint $i$, en algun cas, s'interessaren fins $i$ tot per fer-ne repoblar algun. Per exemple, Pere el Cerimoniós manà que fossin plantats roures i alzines al bosc que voltava el castell de Perpinyà. Sembla que un dels oficials reials n'havia volgut treure un bon rendiment amb l'explotació de la llenya i que el castellà de la fortalesa se n'havia lamentat prop del monarca, afirmant que un bosc que ennoblia tant el castell aviat desapareixeria ${ }^{12}$. No sabem si l'interès per aquest bosc era només per l'estètica o més aviat per la caça que podia contenir, que era una

7 ACA, C, reg. 2229, f. 42 r. (1397, novembre, 13).

8 ACA, C, reg. 2248, f. 206 r.-v. (1406, abril, 29).

9 ACA, C, reg. 203, ff. 224 r.-225 v. (1307, gener, 26). Cit. a M. T. FERRER I MALlOL, Organitzacio $i$ defensa d'un territori fronterer. La governació d'Oriola en el segle XIV, Barcelona, Institució Milà $i$ Fontanals. CSIC, Barcelona, 1990, p. 10.

10 ACA, C, reg. 340, f. 192 r. (1296, juliol, 2).

11 P. BELLOT, Anales de Oribwela (siglos XIV-XVI), ed. a cura de J. TORRES FONTES, Oriola, 1954-56, II, p. 9.

12 ACA, C, reg. 1263, f. 71 r. (1379, gener, 11). 
de les principals distraccions dels reis. Segurament que fou aquest darrer motiu el que mogué Joan I a prohibir que fossin tallats arbres al bosc de Torroella ${ }^{13}$.

Veurem a continuació alguns dels perills que amenaçaven la conservació dels boscos; després, les diverses modalitats d'explotació dels recursos forestals i, finalment, la protecció dels espais naturals mitjançant les deveses.

\section{ELS PERILLS DE DESTRUCCIÓ DELS BOSCOS}

\section{Obtenció de cendres}

Una de les activitats més perjudicials, perquè significava l'anihilació completa del bosc, fou el negoci d'obtenció de cendres, que apareix en els primers anys del segle XIV, bé que hi ha un precedent de l'any 1293; en efecte, la carta de població de Paüls, atorgada per Joan Despuig, que establí un impost per la llenya, la fusta o el carbó venuts pels veïns als forasters, menciona també la cendra al costat d'aquests productes del bosc i per a tots estableix una taxa d'un diner per somada ${ }^{14}$.

Cap a l'any 1316 aquesta mena de negoci degué créixer o algú advertí la cort del perill que representava. Sembla que alguns mercaders estrangers havien vingut a les costes de Catalunya, on compraven arbres dels boscos, els cremaven i després n'exportaven les cendres. Els documents no indiquen ni l'origen dels mercaders que es dedicaven a aquest negoci tan estrany ni tampoc la destinació de les cendres. Hom en pot fer, doncs, totes les hipòtesis que vulgui; potser la més creïble és que aquestes cendres havien d'ésser usades per a l'adob de pells. Tot rellegint l'esplèndida obra de la Sra. Thérèse Sclafert sobre els conreus, els boscos i les pastures de l'Alta Provença, hem pogut veure que, segons els estatuts de Grasse de 1260, hom hi tractava les pells amb calç i amb cendra ${ }^{13}$; vint pells necessitaven de 8 o 7 sesters de calç -segons les qualitats- i 4 de cendra. Això havia de suposar una demanda de cendra molt important, que segurament els boscos pròxims no podien satisfer. Així, doncs, els misteriosos mercaders estrangers que venien a Catalunya per a obtenir cendres podien ésser provençals. Ignorem si aquest sistema d'adobar les pells s'usava a altres llocs, cosa que ampliaria els territoris d'origen possible dels mercaders incineradors. En terres catalanes els materials utilitzats per a adobar cuiros eren la sal, el roldor i el sumac; per això el negoci de la cendra degué sobtar més ${ }^{16}$.

Malgrat que les cendres eren un adob conegut $i$ usat per a la terra de conreu, no creiem que el negoci de les cendres anés encaminat a l'agricultura, ja que no hauria estat remunerador.

Aquest tipus d'explotació del bosc alarmà molt el rei Jaume II, que l'any 1316 féu publicar una ordinació a tots els llocs marítims dels dominis reials prohibint que

13 Sobre la prohibició de tallar arbres al bosc de Torroella cf. la nota. 4. 356.

14 J. M. FONT RIUS, Cartas de población y franquicia de Catalutia, CSIC, Barcelona-Madrid, 1969, I, doc.

15 T. SCLAPERT, Cultures en Haute-Provence. Diboisements et paturages an Moyen Afe, pp. 64-65.

16 C. CARRÉRE, Barcelona, 1381-1462. Un centre económic en ipoca de crisi, Barcelona, Ed. Curial i Fundació S. Vives Casajuana, 1977, 
els estrangers exportessin fusta o que la tallessin i la cremessin per fer-ne cendra, ja que es necessitava per a fer galeres i llurs aparells. A més, el monarca manà al comte d'Empúries, que era feudatari seu pel vescomtat de Bas, que impedís aquesta mena d'explotació en els boscos del vescomtat, on hi havia fusta molt adequada per a rems $^{17}$. Un manament semblant fou fet també a Bernat de Cabrera ${ }^{18}$.

No ens consta que més endavant hi hagués cap més intent de tornar a posar en marxa la fabricació de cendres.

\section{Obtenció d'artigues}

A Catalunya i a Aragó, la necessitat de fer retrocedir el bosc i d'ampliar els camps de conreu, per tal d'afrontar l'augment demogràfic dels segles XII-XIV, no es féu sentir amb tanta intensitat com a la resta d'Europa perquè els excedents demogràfics trobaren noves terres on viure gràcies a l'expansió territorial de la Corona catalano-aragonesa cap al sud, guanyant terres ocupades per l'Islam.

Així i tot, també hi hagué expansió dels camps de conreu a costa dels boscos, però aquesta pràctica trobà l'oposició del rei Jaume II, al començament del segle XIV. N'és un exemple ben clar el manament adreçat al consell de Biescas, a Aragó, el 30 d'agost de 1320 . El justícia d'Aragó havia fet saber al rei que alguns homes del lloc tallaven pins i avets dels boscos del terme i els cremaven per tal de fer artigues; el monarca ho prohibí tot seguit al.legant que la terra de les artigues no era gaire bona i per tant reportaria poc profit, mentre que els arbres eren molt necessaris per a la construcció de naus i galeres i redundaven en benefici de tot el regne; els autoritzà només a tallar la llenya i la fusta que necessitessin per a usos domèstics i per a la construcció de cases: bigues, taules i portes ${ }^{19}$.

Aquest manament del monarca era en realitat el segon advertiment fet als veïns de Biescas. El 15 de març del mateix any ja havia manat al justícia i als jurats d'aquesta població que prohibissin que els veïns fessin tales i calessin foc als boscos de la població, que eren d'utilitat per a la cosa pública, sobretot des que s'havien fet passos per a poder treure la fusta. Ja llavors el rei havia aclarit que els veïns de Biescas podien tallar fusta per a llurs cases, però que no volia, sota pena de 100 sous, que destruïssin els boscos ${ }^{20}$. Però, tal com hem pogut veure, aquesta primera advertència havia resultat inútil.

Cal indicar que a Aragó hi havia una pràctica molt arrelada de conreu en àrees boscoses de propietat comuna, l'escali. Un fur concedit per Jaume I a les Corts d'Osca establí que qui posés fites en un terreny de muntanya o d'erm i el roturés en el termini dels seixanta dies següents podia apropiar-se'l, bé que el perdia si no el conreava durant dos anys seguits. Les ordinacions particulars de cada vila o comunitats d'aldees ampliaren o restringiren aquest empriu $\mathrm{i}$ algunes concretaren que hom no podia fer escalis a les deveses o boalars si per obtenir-los calia tallar arbres ${ }^{21}$.

17 ACA, C, reg. 243 , f. 54 r. (1316, febrer, 17).

18 Ibidem, f. 68 v.

19 ACA, C, reg. 246, f. 104 r. (1320, agost, 30).

20 ACA, C, reg. 245 , f. 300 v. (1320, marc, 15).

21 J. COSTA, Coloctivismo agrario en Espanta, II. Hecbos, introducción y edición de C. SERRANO, Zaragoza, 


\section{Incendis provocats per pastors i agricultors}

Un altre dels perills que amenaçaven els boscos eren els incendis estiuencs provocats pels pastors que cremaven herbes per obtenir-ne de millors l'any següent i pels pagesos que cremaven rostolls o netejaven marges, recs o rambles. Malgrat que era una qüestió que entrava més aviat dins el camp de les ordinacions municipals, en alguna ocasió també foren dictades ordres contra aquesta mena de focs des de la cancelleria reial. N'hi ha diversos exemples.

L'any 1312 hi havia hagut un litigi entre el justícia i el Consell d'Oriola, d'una banda, i el guardià de les cabanyes de ramats d'Aragó que baixaven a hivernar-hi, Ximèn Ortiz, de l'altra. Els oriolans acusaven els pastors aragonesos d'haver calat foc a les muntanyes de llur terme i, malgrat que els pastors asseguraven que el foc s'havia produït de manera fortuiita, dos d'ells estigueren empresonats quatre mesos per aquest motiu i hagueren de pagar una multa de $\mathbf{4 0 0}$ sous, que el rei Jaume II demanà que els fos perdonada. Arran d'aquest foc, que potser no era el primer, Jaume II manà al procurador del regne de València dellà Xixona, al batlle general $\mathrm{i}$ al justícia i al Consell d'Oriola que fessin una crida prohibint que els pastors calessin foc a les muntanyes del terme sota pena de 60 morabatins d'or. Un cop feta la crida, podrien exigir efectivament la multa a qui hi fes foc ${ }^{22}$.

Una intervenció semblant es produí a Xàtiva. Pel juny de 1327 Jaume II manà al lloctinent de governador en el regne de València dellà Xúquer que prohibís calar foc a les muntanyes, boscos, herbes i rambles del terme de Xàtiva durant l'estiu, a causa dels perjudicis que causaven als veïns d'aquesta vila. Els infractors havien de pagar una multa de 100 sous $i$, si no la pagaven en el terme de deu dies després de la notificació, havien de fer trenta dies de presó ${ }^{23}$.

Molts anys després, Pere el Cerimoniós s'interessà per l'incendi intencionat dels margallons que poblaven les muntanyes del terme del castell de Cubelles i, amb un manament que adreçà, el 12 de juliol de 1368, al veguer de Vilafranca i al batlle del castell de Cubelles, intentà salvar aquests arbres de la destrucció. El margalló és un arbre baix, de fulles grosses en forma de ventall $\mathrm{i}$ amb espines vulnerants: és una palmera autòctona d'Europa i és, a més, la base d'una artesania, en regressió, però present encara en diferents llocs de les terres catalanes, de fabricació d'escombres $\mathrm{i}$ objectes de cistelleria. Precisament, la importància d'aquesta artesania en l'economia dels habitants de Cubelles, fou un dels motius que justificaven, a ulls del rei, la prohibició d'aquests incendis provocats, igual com la constatació que, quan es calava foc als margallons, cremaven també oliveres $i$ altres arbres fruiters. Bé que no hi ha comentaris sobre els motius dels incendiaris, podriem avançar la hipòtesi que eren pastors, que potser opinaven que els margallons destorbaven el bestiar o li feien mal, a causa de les espines, o que impedien el creixement de l'herba. El rei establí una

Guara ed., Instituto de Estudios Agrarios, Pesqueros y Alimentarios, 1983, pp.14-19.

22 ACA, C, reg. 208, f. 108 r. (1312, febrer, 3), i f. 118 r.(1312, mars, 6), reg. 209, f. 127 r. (1312, mars, 29) publicat aquest darrer per J. M. del ESTAL, Colección docmmental del Medievo Alicantino, II. Años 1306-1380, Alacant, Publicaciones de la Universidad de Alicante, 1988, doc. 58.

23 ACA, C, reg. 2509, f. 37 r.-v. (1327, juny, 23). 
multa de 200 sous, que haurien de pagar els infractors de l'ordre ${ }^{24}$.

Tots tres exemples demostren l'interès de la Corona per preservar els boscos dels incendis provocats per l'home, directament o indirecta. En algun cas, quan els indicis apuntaven cap a un incendi intencionat i maliciós d'un bosc, la Corona no dubtà a confiar la qüestió a la justícia. És aquest el cas d'una devesa a Granadella, cremada segons es digué pels veïns de Llardecans, població del Segrià que pertanyia a Nicolau de Santcliment, ciutadà de Lleida ${ }^{25}$.

\section{L'EXPLOTACIÓ DELS BOSCOS}

\section{Obtenció de carbó}

Entre els recursos que hom extreia dels boscos figurava el carbó vegetal, indispensable per a diversos processos industrials o artesanals, especialment per als treballs amb metalls, ja que el carbó mineral no era usat encara o almenys no en tenim notícies. El procediment que hom seguia era, com ja és sabut, fer una pila de fusta, tapada amb llenya verda, herba i terra, amb un forat o xemeneia al mig, per on s'encenia. La combustió era regulada mitjançant forats laterals, que permetien la circulació controlada d'aire fins que s'obtenia la carbonització de la fusta. Sembla que hom usava també forns oberts, d'obra i permanents, que permetien una producció de carbó gairebé industrial. No cal dir que la fabricació de carbó exigia una gran quantitat de fusta $i$ que, per aquest motiu, constituïa un perill molt important per a la conservació dels boscos, especialment en el segon procediment, que incidia continuadament en un mateix espai. Això induí el rei Pere el Cerimoniós a prohibir aquesta mena de forns permanents en unes ordinacions del 1345 per als comtats de Rosselló i de Cerdanya ${ }^{26}$.

Les fargues, en particular, necessitaven una gran quantitat de carbó i sotmetien els boscos veïns a tales incessants. A vegades el rei demostrà la seva preocupació per aquesta tala pel mateix motiu de sempre: perquè podia deixar el país sense arbres útils per a la construcció naval. Les nostres notícies es refereixen exclusivament a les fargues de les conques mineres de Bielsa i de Gistau, que eren reials.

El 23 de febrer de 1326, per exemple, Jaume II manà a Garcia de Castre, batlle de Sobrarb, les Valls i la Llitera, que impedís que els llenyataires i els carboners tallessin arbres i després en fessin carbó per a les fargues de Bielsa i de Gistau, ja que creia que eren adequats per $a$ arbres $i$ antenes de vaixells i no volia que es destruissin. El batlle tenia facultat per a indicar els llocs on no es podia tallar fusta ni fer carbó.

Aquest manament reial i la seva aplicació per part de Garcia de Castre provocà les queixes dels arrendadors dels impostos reials de les fargues de Bielsa, que deien que amb el pretext del manament reial Garcia de Castre els prohibia tallar llenya en

24 ACA, C, reg. 738, f. 8 v. (1368, juliol, 12).

25 ACA, C, reg. 141, f. 47 r.-v- (1307, setembre, 28).

26 Ch. RENDU, Quolques jalons pour wne bistoire des formes en Cerdagne, p. 249. 
els boscos reials de Bielsa i Gistau, com s'havia fet sempre; això repercutia en una disminució de les rendes reials de les fargues, que eren assignades per a cavalleries a diversos nobles. Segons els arrendadors, els arbres que tallaven no eren adequats per a la construcció naval $i$, per aquest motiu, el rei reconsiderà la seva decisió $i$ anul.là el manament, recomanant, però, que vigilessin de no talar arbres que servissin per a arbres, antenes $o$ rems de vaixells $i$ especialment faigs $o$ avets, bé que si $n$ 'hi havia d'aquestes dues espècies que no servien per a aquests usos també podien ésser tallats ${ }^{27}$

La fabricació d'armes $\mathrm{i}$ objectes de ferro en general i l'encunyació de moneda eren algunes altres de les feines on el carbó era necessari. L'any 1321, per exemple, Jaume II donà instruccions al batlle del Coll de Balaguer perquè facilités la tasca de Pere de Santmartí, que el rei hi enviava per a disposar que s'hi fes el carbó necessari per a la moneda que llavors s'encunyava a Barcelona ${ }^{28}$.

Així com les encunyacions no eren contínues i potser per la seva excepcionalitat trobem aquesta mena de notícies, la fabricació d'armes $\mathrm{i}$ d'utensilis de ferro a les ferreries era una activitat habitual; però, com que era privada, no tenim gaire informació del volum de carbó que consumien els ferrers ni d'on s'aprovisionaven; a més, a vegades eren els mateixos clients els qui el portaven. Alguna carta de població catalana com la de Castles, lloc situat a tocar del Montcaro, precisà, l'any 1237, que la ferreria era del senyor, Ramon de Sentmenat, però que els veïns hi podrien reparar llurs eines, si hi portaven el carbó necessari; si volien que el ferrer els en fes de noves, havien de portar-li el ferro i el carbó i pagar-li en diners i en espècies la seva fei$\mathrm{na}^{29}$.

Molt rarament tenim notícies del carbó usat per a la fabricació d'armes. Durant la guerra amb Castella, l'any 1363, el rei Pere el Cerimoniós s'interessà per assegurar el proveïment de carbó a Saragossa, on feia fer aparells de ferro per a la guerra, i ordenà que fos proporcionada escolta armada als carboners i a les bèsties que el por$\operatorname{taven}^{30}$.

El carbó era necessari també per a usos domèstics. L'establiment d'un lloc anomenat Coma Bardina atorgat, l'any 1294, pel prior de la cartoixa de Scala Dei, establí que els concessionaris no podrien fer carbó per a vendre, llevat de quan arrabassessin o artiguessin bosc per a obtenir terres de conreu, però que sí que podrien fer-ne per a ús propi ${ }^{31}$.

L'explotació dels boscos per a obtenir fusta, llenya i carbó fou causa de litigis, a vegades violents, entre els pobles veïns. L'any 1321 , per exemple, n'hi havia un entre Llagostera i Tossa. Els veïns de Llagostera tallaven fusta a Tossa per a fer carbó i els

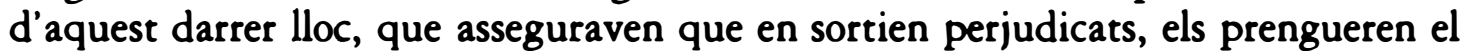
carbó i la fusta; com a represàlia els de Llagostera prengueren als de Tossa totes les penyores que trobaren a l'abast. Com que el litigi amenaçava de pertorbar l'ordre

27 ACA, C, reg. 249, f. 117 r.-v. (1326, febrer, 23). Ff. 167 v.-168 r. (1326, juny, 12).

28 ACA, C, reg. 246, f. 226 v. (1321, juny, 8).

29 J. M. FONT RIUS, Cartas de población y franquicia de Cataluña, I, doc. 270.

30 ACA, C, reg. 1187, f. 158 v. (1363, maig, 15).

31 J. M. FONT RIUS, Cartas de población y franquicia de Cataluna, II, CSIC. Institución Milá y Fontanals, Barcelona, 1983, doc. 405. 
públic, Jaume II manà al batlle general de Catalunya, Ferrer de Lillet, que hi anés i el resolgués ${ }^{32}$.

Sabem que també hi hagué algun plet d'aquesta mena entre Múrcia i Oriola perquè els límits dels termes d'ambdues poblacions, que al mateix temps eren frontera entre ambdós regnes, no eren prou definits; l'any 1307 don Juan Manuel proposà que, mentre es resolia el plet, els terrenys disputats poguessin ésser aprofitats conjuntament $\mathrm{i}$ tots hi poguessin caçar, fer-hi llenya $\mathrm{i}$ carbó, pasturar-hi el bestiar $\mathrm{i}$ collir-hi grana ${ }^{33}$. A les comarques frontereres del País Valencià el problema era particularment greu perquè hi havia poques zones boscoses, que eren sobreexplotades per a tots els usos. A Elx, el Consell de la vila prohibí algunes vegades que els pins de les serres del Port i del Molar s'utilitzessin per a fer carbó, ja que eren més indispensables per a fornir bigues per a la construcció ${ }^{34}$. Els veïns d'Oriola acudien a fer carbó a les terres poc poblades situades al sud del Segura prop de la frontera amb Castella ${ }^{35}$.

La sobreexplotació del bosc per a fabricar carbó destinat a l'exportació podia ésser tant perjudicial o més que tots els usos dels quals hem fet esment. Sembla que a Navarra, cap a l'any 1300, hom havia prohibit de fer carbó, almenys a les contrades meridionals, i que això repercutí en una forta demanda d'aquest combustible a la comarca aragonesa de Tarassona, propera a la frontera navarresa, que féu témer que comportés la destrucció dels boscos d'aquesta àrea. El rei prohibí, doncs, que els homes de los Fayos, que devien dedicar-se a aquest negoci, fessin carbó per a exportar a Navarra i manà que fessin només el que era habitual ${ }^{36}$.

\section{Obtenció de llenya per a ús domèstic}

La llenya i el carbó, també derivat de la llenya, eren l'única font calorífica coneguda a l'Edat mitjana per a escalfar la casa a l'hivern i per a cuinar. Eren, per tant, una matèria bàsica per a la vida humana $i$, per això, el dret de fer llenya als boscos per a proveir la llar fou una preocupació constant en tot l'àmbit rural catala, valencià $i$ aragonès. Tots els pobles procuraren assegurar-se des de ben antic algun lloc on poder-se'n abastar. Les cartes de població, concedides després de la reconquesta o més endavant a comunitats de veîns, o bé les donacions a diversos nobles de terres per repoblar, solien fer referència al dret dels veïns a usar les pastures, els boscos, les aigües, les pedres, la caça etc. i sovint concretaven que podien tallar llenya i fusta ${ }^{37}$. En algun cas, però, com a la carta de població de Paüls, concedida per Joan

32 ACA, C, reg. 246, f. 247 v. (1321, juliol, 18).

33 ACA, C, cr. Jaume II, núm. 3122 (1307, febrer, 4), cit. a M. T. FERRER I MALLOL, Les aljames sarratines de la govermació d'Oriola en el segle XIV, Barcelona, Institució Milà i Fontanals. CSIC, 1988, p. 117.

34 A. RAMOS FOLQUÉS, La industria, el comercio y la agricultura en Elche, Elx, 1974, p. 259.

35 P. BELLOT, Anales de Oribuela (siglos XIV-XVI), II, Pp. 203-204, 206, 207 etc.

36 ACA, C, reg. 117, f. 127 r. (1300, maig, 25).

37 J.M. FONT RIUS, Cartas de población y franquicia de Catalunta, I, cf. entre les donacions de terres per repoblar: docs. $25,43,63,64,82,85,89,109,110,133$ etc; cf. entre les cartes de població concedides a comunitats de veïns: docs.75 (Tortosa, 1149),79 (Lleida, 1150), 86 (Vinaixa, 1151), 88 (Vimbodi, 1151), 90(Vinaixa, 1152), 94 (Ciurana, 1153), 99 (Duas Aquas i Vilavert, 1155), 113 (Prades, 1159), 122 (Agramunt, 1163), 123 
Despuig l'any 1293, hom féu distinció entre llenya i fusta per al consum domèstic dels veîns, que era un empriu franc, i la que es venia a forasters, que havia de pagar un impost d'un diner per somada ${ }^{38}$. En un altre cas, a la carta de població de Sant Hilari Sacalm, atorgada per Bernat de Gurb l'any 1337, els veïns tenien empriu de llenya a tot el terme del castell de Solterra, mentre no fessin mal als arbres ${ }^{39}$.

A vegades, les cartes de població $i$ algunes donacions foren contradictòries, per exemple la carta de població de Tortosa de 1149 donà als habitants d'aquesta ciutat l'ús dels boscos del terme, que era d'una gran extensió, i l'any 1168 Alfons I donà Paüls, que era comprès dins d'aquest terme, a tres cavallers, amb pastures, caça i muntanyes $i$ tot allò que fes servei als homes ${ }^{40}$; com veurem, la superposició de drets donà lloc a litigis entre Tortosa i Paüls pels emprius de llenya i fusta en el segle XIV.

En alguns casos, com en el de la donació del Puig de Montesquiu, al terme d'Àger, feta per Arnau Mir de Tost l'any 1066, el donatari reservà a favor dels veïns d'Àger els emprius de caça, pastura i llenya en el terme ${ }^{41}$. Posteriorment, però, tant si hi havia reserva expressa d'un empriu com si era consuetudinari, quan coincidiren les apetències dels uns i dels altres en una mateixa àrea boscosa s'originaren multitud de plets entre poblacions veïnes, que a vegades desembocaren en baralles $\mathrm{i}$ ferits.

També els monestirs, els nobles i el mateix rei es reservaren alguns boscos, tant per a obtenir-ne llenya i fusta com per a reserva de caça. Les llicències per a tallar-hi llenya o fusta foren llavors molt limitades, llevat d'algun cas excepcional. L'hivern de 1351, per exemple, fou molt fred a la Cerdanya; hi caigueren grans nevades $i$ les reserves domèstiques de llenya degueren exhaurir-se; la població degué trobar dificultats per a proveir-se'n i per això el rei Pere el Cerimoniós autoritzà,a mitjan febrer, que en poguessin tallar al bosc del castell de Querol, cadascú per al propi ús. El procurador de les rendes reials al Rosselló i a la Cerdanya, però, hi havia d'anar personalment per a determinar on es podria fer llenya i evitar danys greus al bosc $^{42}$.

Catalunya.- Al Principat, els conflictes entre poblacions veïnes per l'usdefruit dels boscos foren molt nombrosos $\mathrm{i}$ alguns arribaren a la violència, com s'esdevingué entre Vinaixa i Omells d'una banda i Arbeca, Borges Blanques i Castellots de l'altra, o entre Prenafeta i Barberà l'any $1298^{43}$. Sembla que els homes de Barberà, que pertanyia a l'orde del Temple, tenien empriu de fer llenya i de pasturar els ramats a Prenafeta i a Figuerola, però que malgrat això foren molestats i reberen danys en persones $\mathrm{i}$ coses. Llavors els de Barberà atacaren els de Prenafeta $\mathrm{i}$ de Figuerola,

(Menìguens, 1163), 125 (Villa Constantina, 1164) etc., 354 (Sant Llorenç de Morunys, 1290), 374 (Sant Hilari Sacalm, 1337).

38 J. M. FONT RIUS, Cartas de población y franquicia de Catalutia, I, doc. 356.

39 J. M. FONT RIUS, Cartas de población y franquicia de Cataluna, I, doc. 374.

40 J. M. FONT RIUS, Cartas de población y franquicia de Catalunta, I, docs. 75 i 134.

41 J. M. FONT RIUS, Cartas de población, I, doc. 30.

$42 \Lambda C A, C$, reg. 892 , ff. 150 r. i 161 v. (1351, febrer, 10 i 16).

43 ACA, C, reg. 107, ff. 210v.-211r. (1298, gener, 22). 
violant els privilegis del monestir de Poblet $i$, per aquesta causa, el veguer de Montblanc n'agafa alguns com a hostatges. Pel maig, el rei li ordenà que els deslliurés perquè estaven disposats a seguir la via judicial en la resolució del plet ${ }^{44}$.

També hi hagué discussions entre pobles i monestirs o nobles, cadascú defensant els seus drets.

Així, per exemple, l'any 1258 , Jaume I prohibí que es fes llenya als boscos i a les deveses de Rocamora i de Bellmunt, prop de Cervera, que pertanyien al priorat de Montserrat ${ }^{45}$. També Jaume II defensà els drets del monestir de Santes Creus contra els homes de Santa Maria del Pla (el Pla de Santa Maria actualment), que havien tallat llenya en una partida de terra del monestir, anomenada "Coma Estremera». El monestir afirmava que no hi tenien cap empriu i que, a més, havien causat danys, ja que havien pres un bou, relles i aixades als homes de Santes Creus ${ }^{46}$. També hi hagué discussions pels emprius de llenya entre els veïns de Solivella i els de Forès, llocs que pertanyien tots dos al monestir en aquell moment ${ }^{47}$. A mitjan segle XIV, l'abat de Santes Creus es queixà al rei Pere el Cerimoniós perquè un donzell anomenat Ramon de Soler, sense permís de l'abat, tallava arbres i llenya al bosc de Guils, que el monestir tenia a la Cerdanya, i a més feia pasturar el seu bestiar a les deveses $\mathrm{i}$ als camps de blat dels veïns del lloc. Els homes de Guils vivien en part de vendre llenya $\mathrm{i}$ fusta del bosc; per això l'abat temia que, si hom els privava d'aquest recurs i, a més, eren damnificats en els conreus $i$ en les pastures, marxarien a viure en un altre $11 \mathrm{c}^{48}$.

Poblet topà amb els homes del Temple de l'Espluga de Francolí, que havien tallat fusta en el bosc del monestir, motiu pel qual el veguer de Montblanc els exigia una multa de 1000 morabatins, multa que, segons el comanador de Barberà, de l'orde del Temple, era il.legal ${ }^{49}$.

Jaume II, en canvi, els anys 1292 i 1297, defensà els homes de Montanyana, a la Ribagorça, en el seu dret de fer llenya a la muntanya de la Pedrinyera, situada al terme de Girbeta i de Montfalcó, que usufructuaven des de feia més de cinquanta anys $\mathrm{i}$ que els era impedit primer per Acard de Mur i per Amalric de Vallsegura i després per Amalric de l'Estall's. L'any 1301 el comanador del Temple a Gardeny es queixà perquè Alamanda de Cervera impedia que els homes d'Artesa de Lleida, de Madrona i de la Sala, que pertanyien al Temple, fessin ús de l'empriu que tenien de fer llenya i de pasturar el bestiar al terme de Castelldàsens, que era d'Alamanda" .

També hi hagué discussions entre els veïns dels llocs de Prats i de la Manresana i el senyor del castell de Rubió per l'empriu que els primers asseguraven que tenien per a fer llenya i pasturar els ramats en el terme del castell, entre els anys $1307 \mathrm{i}$

44 ACA, C, reg. 111, f. 211 v. (1298, maig, 21).

45 ACA, C, reg. 9, f. 8 (1258, gener, 8).

46 ACA, C, reg. 117 , f. 69 v. i 72 v. (1300, maig, 9).

47 ACA, C, reg. 139, f. 246 r. (1307, maig, 1).

48 ACA, C, reg. 722 , f. 149 r.-v. i reg. 724 , ff. 8 v. -9 r.(1365, agost, 14).

49 ACA, C, reg. 123, f. 54 v. (1302, mars, 23). Un any després, Poblet continuava queixant-se dels qui tallaven llenya al bosc del monestir contra la voluntat de l'abat: reg. 127, f. 20 r. $(1303$, març, 3).

50 ACA, C, reg. 91, f. 35 v. (1292, febrer, 15) i reg.109, f. 231 v. (1297, agost, 3).

51 ACA, C, reg. 122, f. 187 v. -189 r. (1301, agost, 9). 
1308. El rei es reservà la sentència del plet que enfrontà ambdues parts i el procurador de Catalunya, Bernat de Fonollar, hagué d'anar al terme de Rubió per fer-hi plantar fites, que havien de limitar el terreny on els veïns de Prats i de la Manresana podrien exercir l'empriu; però Berenguer de Castellolí, senyor de Rubió, es queixà poc després que no les respectaven. Jaume II, doncs, hagué de manar al governador de Catalunya que hi tornés, fes respectar les fites i fes escriptura pública dels drets de cadascús'.

A Tortosa i la seva rodalia hi hagué plets, també, per l'usdefruit de determinats boscos, com el de Paüls, població situada al nord-oest de Tortosa, prop dels ports de Beseit, en un terreny accidentat, amb molta arbreda. Joan Despuig al.legava drets sobre aquest bosc, ja que era senyor del lloc, però Tortosa també n'hi tenia, perquè era dins l'extens terme que li havia estat assignat des de la conquesta ${ }^{33}$. Resolgué la qüestió una sentència, que hagué de menester un aclariment reial l'any 1305; segons ambdós pronunciaments, Joan Despuig només podria impedir que els ciutadans de Tortosa fessin llenya a la quarta part del bosc, que quedava reservada per al seu ús i dels seus homes o per a les persones a qui ell ho autoritzés. A les tres quartes parts restants del bosc, els veïns de Tortosa hi podien fer llenya i tallar fusta per a ús domèstic, per a la construcció de cases i de vaixells i també per a vendre, si volien, com podien fer-ho a la resta del terme de Tortosa. Tot el bosc, a més, era lliure per al pasturatge $e^{54}$.

Tortosa vetllava també per l'arbreda de la serra de Montsià, a la veïna Amposta. A la primeria de l'any 1308 el batlle tortosí havia fet arribar queixes al rei Jaume II per la tallada de fusta, sense llicència, al Montsià i degué acusar el batlle d'Amposta de rebre diners dels homes que la tallaven i se l'enduien, per mar i per terra, en grans quantitats. La resposta del rei fou la de manar que no s'hi tallés fusta sense llicència. El batlle i els homes d'Amposta s'ho prengueren tant al peu de la lletra que poc després intentaren impedir que els enviats de Bernat de Llibià, a qui el rei ho havia encomanat, hi tallessin fusta per a la Corona i els hagué d'enviar un altre manament perquè els restituiissin les viandes $i$ els estris que els havien presos i els deixessin treballar"s.

Cal dir que hi havia pobles que s'excedien en l'ús de fer llenya. Pere de Gravalosa, ciutadà de Manresa, que posseïa el castell de Castellar, es queixà l'any 1300 perquè els homes de Prats, que asseguraven que tenien empriu de llenya en el terme del castell, hi tallaven alzines $\mathrm{i}$ alguns altres arbres que eren útils per a més usos que la llenya. Segurament ell havia intentat impedir-ho i com a conseqüència els homes de Prats, reunits en la milícia pagesa del sagramental, havien atacat i robat alguns masos del terme, hi havien calat foc $i$ havien fet danys diversos ${ }^{36}$.

També els veïns d'Eramprunyà foren acusats de fer una explotació desmesurada del bosc, potser per la proximitat de Barcelona i per la gran demanda de fusta i llenya

52 ACA, C, reg. 142, f. 55 r. (1308, juny, 8).

53 Cf. sobre el cas de Paüls abans, les notes 38 i 40.

54 ACA, C, reg. 136, f. 158 r.-v. (1305, agost, 9).

55 ACA, C, reg. 140, f. 93 v. (1308, gener, 23) i f. 103 r.-v. (1308, febrer, 11).

56 El rei manà al veguer de Manresa que, si els homes de Prats tenien l'empriu de llenya, vigilés que no causessin danys: ACA, C, reg. 115 , ff. 283 v.-284 r. 
que en devia arribar. L'any 1303 Jaume II havia sabut que alguns barcelonins i gent d'altres llocs hi havien tallat arbres, alguns dels quals entraven en la categoria protegida d'arbres de fruit. Sembla que el bosc havia estat repoblat feia poc i que aquesta tala era llavors molt perjudicial; el rei manà, doncs, al veguer i al batlle de Barcelona que no permetessin que s'hi tallessin arbres". Però el manament no fou suficient ja que alguns anys després, segons una carta del mateix rei al batlle del lloc, del 31 de juliol de 1319, hi havia el perill que no hi quedés cap arbre. En aquesta carta el monarca manà al batlle que congregués la gent de la parròquia al castell i els fes saber que quedava prohibit tallar arbres que fessin glans o altres fruits $i$, per tant, alzines, castanyers, nogueres, lledoners, servers i pins, sota pena de 60 sous $^{58}$.

Del Rosselló $i$ de les Illes en tenim poques notícies perquè durant la primera meitat del segle XIV eren regne independent i és precisament la documentació d'aquesta època la que hem examinat amb preferència.

País Valencià.- L'any 1268 Jaume I havia concedit als valencians llicència per a tallar llenya on volguessin i per a poder traslladar-la sense pagar lleudes ni peatges, però a la realitat aquesta autorització no era tan general com semblava ${ }^{39}$. Com a Catalunya, també al País Valencià hi hagué litigis entre poblacions veïnes pel dret de fer llenya. L'any 1273 Jaume I havia autoritzat els veïns del castell i vila de Peníscola per a tallar llenya i fusta als termes de Morella i Benifassà, per tal que poguessin construir-se cases, fer bótes per al vi, etc. ${ }^{60}$. L'any 1284 Pere el Gran manà també al batlle, al justícia i als jurats de Morella que no impedissin a l'abat del monestir de Rueda tallar fusta en el terme ${ }^{61}$. Però els veïns de Morella no estigueren d'acord en l'usdefruit de llurs boscos per gent d'altres poblacions. Sabem que en el segle XIII hi hagué un procés entre els habitants de Morella, d'una banda, i el comanador de Cervera i els homes del seu terme, de l'altra, per l'empriu dels boscos i pel dret de tallar llenya dins el terme de Morella. L'any 1292 Jaume II manà que fos respectada la sentència pronunciada sobre aquesta qüestió ${ }^{62}$, però ens consta que l'any 1304 continuava la tensió i que el batlle de Morella prenia penyores als homes de l'orde de l'Hospital pel valor de les multes imposades als qui treien fusta del terme de la vila. El procurador de l'orde de l'Hospital se'n queixà al rei i advertí que així sortia perjudicada gent innocent ${ }^{63}$. Els veïns d'Ademús, una comarca boscosa també, es veieren afectats igualment per llicències de tallades de fusta autoritzades pel rei. L'any 1283 el justícia i el consell d'Ademús reberen l'ordre de respectar el

57 ACA, C, reg. 130, f. 228 v. (1303, dsembre, 15). juliol, 31).

58 La prohibició esmentava també els arbres aptes «ad tigna»: ACA, C, reg. 245, ff. 164 v.-165 r. (1319,

59 J. E. MARTÍNEZ FERRANDO, Catálogo de la documentación relativa al antiguo reino de Valencia contenida en los registros de la Cancilleria real, I, Jaime I el Conquistador, Madrid, 1934, doc. 719. 1439.

60 J. E. MARTÍNEZ FERRANDO, Catálogo de la documentación relativa al reino de Valencia...I. Jaime I, doc.

61 J. E. MARTÍNEZ FERRANDO, Catálogo de la documentación relativa al Reino de Valencia..., II. Pedro el Grande, doc. 1995.

62 ACA, C, reg. 92, f. 5 v. (1292, març, 26).

63 ACA, C, reg. 134,144 v. (1304, novembre, 17). 
permís exclusiu que tenia Abraham Toledano, veí de Terol, per a tallar arbres als boscos del terme ${ }^{64}$.

Els litigis es transformaren a vegades en atacs armats entre poblacions veïnes per causa de l'usdefruit de llenya i pasturatges. Per exemple, els propietaris de l'alqueria de Cotes es queixaren de l'agressió a mà armada que havien sofert l'any 1296 per part de veïns del lloc de Pardines i de la continuació dels atacs contra els treballadors de l'alqueria, robatori d'animals de llaurar, etc., com també de l'usdefruit il.legal de llenya $i$ de pasturatges durant l'any $1297^{63}$.

En canvi, Poblet es queixà l'any 1298 que els veïns de Manises, Paterna i Riba-roja impedien als sarraïns de Quart, lloc que pertanyia al monestir, de tallar llenya menuda i grossa en els termes esmentats i de treure'n calç, pedra, guix i terra, tant per a ús propi com per a vendre ${ }^{66}$.

A les contrades meridionals del País Valencià, de clima molt sec i amb poca vegetació arbòria, hi hagué discussions entre Alacant i Agost, per exemple, l'any 1317, per l'empriu de llenya i de pastures d'aquest darrer 1 loc $^{67}$. També Petrer es queixà, l'any 1388, perquè els veïns d'Elda anaven a fer llenya i a tallar fusta a les muntanyes del seu terme, tot i que no tenien reconegut aquest dret per cap ús antic ${ }^{68}$.

Malgrat que els castells gaudien de privilegis per a assegurar llur proveïment, el de Xàtiva tingué dificultats amb els llocs veïns. L'alcaid i els homes que el guardaven tenien el dret de tallar llenya, per a ús de la fortalesa, no solament en el terme propi sinó també en els termes veïns; però l'any 1325 sembla que aquest ús havia estat discutit i fins $\mathrm{i}$ tot havien estat preses penyores a la gent del castell. Això obligà el rei Jaume II a intervenir-hi i a confirmar aquell dret ${ }^{69}$.

Alguns boscos, com el de Salzedella, que pertanyia al monestir de Valldigna, foren preservats de les apetències dels habitants de la rodalia; Jaume II vedà que s'hi fes llenya i la prohibició fou extensiva als oficials reials ${ }^{70}$.

Aragó.- A Aragó, hi hagué infinitat de litigis per l'aprofitament de llenya i de pastures. Això vol dir que els boscos eren escassos i, per tant, cobejats. En efecte, llevat dels paratges situats a tocar dels Pirineus o de la Serralada Ibèrica, Aragó té un clima sec $\mathrm{i}$ àrid, poc propici al creixement del bosc.

A les terres orientals, properes a Catalunya, força seques, hi hagué un bon nombre de plets, algun dels quals tingué episodis violents. Un litigi per pastures i llenya entre Alins i Calassanç comportà un atac a mà armada de l'alcaid de Guerau de Cabrera a Calassanç i dels homes d'aquest lloc contra els d'Alins, l'any 1307. Ramon de Molina, senyor d'Alins, exposà al rei Jaume II que tant Alins com

64 J. E. Martínez Ferrando, Catálogo de documentos relativos al Reino de Valencia..., II, Pedro el Grande, doc. 1770.

65. ACA, C, reg. 106, f. 130 r. (1297, desembre, 3).

6).

66 Jaume II ordenà que els fos respectat l'usdefruit que tenien: ACA, C, reg. 107, f. 281 v. (1298, març,

67 M. T. FERRER I MALLOL, Les aljames sarraines de la governació d'Oriola en el segle XIV, CSIC. Institució Milà i Fontanals, 1988, doc.46.

68 ACA, C, reg. 1831 , f. 129 r.-v. (1388, juny, 18).

69 ACA, C, reg. 248 , f. 280 v. (1325, maig, 1).

70 ACA, C, reg. 198, f. 239 v. (1301, gener, 22). 
Calassanç es regien per fur d'Aragó i que, per tant, podien pasturar llur bestiar d'era en era" $i$ tallar llenya per a ús domèstic en els termes veïns, però que Guerau de Cabrera i els seus homes de Calassanç ho impedien $\mathrm{i}$, per tant, demanà l'ajut del rei, que confià l'afer a Guillem de Castellnou, sobrejunter de Ribagorça, Sobrarb i les Valls ${ }^{72}$.

A les terres pròximes de Barbastre un altre plet enfrontà durant uns quants anys aquesta ciutat amb les poblacions veïnes. L'any 1296 Barbastre es queixà que, malgrat que els habitants de la ciutat tenien dret de pasturar els ramats i de tallar llenya als termes veïns, Garcia de Castellazuelo i altres senyors de la rodalia els impedien aquest dret. Per aquesta causa el rei manà al sobrejunter d'Osca i Jaca, Pere de Montagut, que els defensés, si li constava que era així i estaven disposats a estar a dret als querellants en poder del justícia d'Aragó ${ }^{73}$. Pel novembre de 1302 , Jaume II repetí un manament semblant al procurador d'Aragó, Lope de Gurrea, a petició dels veïns de Barbastre, que continuaven queixant-se dels impediments que hom els posava en aquells emprius ${ }^{74}$. Els nobles, cavallers $\mathrm{i}$ infançons, propietaris dels llocs veïn, reaccionaren contra les provisions obtingudes per Barbastre $\mathrm{i}$ aconseguiren que el rei confiés al sagristà d'Osca, Guillem de Vallsenís, la missió d'escoltar els querellants, rebre testimonis i proves etc. Els senyors afectats eren Garcia de Castellazuelo, senyor de Castillazuelo i d'Almarge; Ramon de Molina, senyor dels llocs de Ilche i de Morilla; Sanç d'Antillón, senyor dels llocs de Castre, Saltavo, el Grado, Artasona i Avinzada; Guillem Dos, senyor dels llocs d'Hoz i Salinas; Arnau de Fontova, Sança Pérez d'Azlor, vídua de Rodrigo Pérez de Caseda, senyors de Peralta, la Coscollola (Coscojuela de Fantova), Salinas de "Uscallola», "Cermito»" i Pozán; i Joan de Tramasset, senyor del vedat de Cillas".

Aigües avall del Cinca també Pomar, que pertanyia als hereus de Felip de Castre, tenia un plet amb el lloc de Barbero" pel dret de fer llenya, pasturar els ramats $\mathrm{i}$ pel nomenament de justícia $\mathrm{i}$ algunes altres qüestions jurisdiccionals ${ }^{78}$.

Prop d'aquests llocs, també tenien problemes els homes de Pertusa. Es queixaven que, segons els furs d'Aragó, podien fer llenya i pasturar d'era en era en els llocs veïns ${ }^{79}$, cosa que els senyors d'aquests llocs, Sanç d'Antillón, Ferrís de Liçana, Llop de Pomar, Pere de Pomar, Rodrigo Pérez de Caseda i els hereus de Fortún de Binyech,

71 El règim de pastura d'era a era consistia en l'aprofitament per part dels ramats d'un poble de les herbes del terme veí per la part fronterera i fins a les eres d'aquest poble i només durant el dia, de la sortida a la posta de sol, moment en el qual havien d'haver tornat al terme propi: M. I. FALCÓN PÉREZ, La ganaderia aragonesa medieval, «Estado actual de los estudios sobre Aragón. Actas de las Terceras Jornadas (1980), II, Saragossa, 1981, p. 895. Per a més informació sobre aquest tema cf. V. FAIRÉN GUILLÉN, La alera foral, Saragossa, 1951.

72 ACA, C, reg. 141, f. 62 v. (1307, octubre, 9).

73 ACA, C, reg. 105, f. 177 v. (1296, novembre, 6).

74 ACA, C, reg. 126, ff. 159 v.-160 r. (1302, novembre, 27).

75 Topònim no identificat.

76 ACA, C, reg. 133 f. 8 v. (1304, juny, 18), f. 12 r.-v. (juny, 20), f. 17 r.-v. (juny, 25), ff. 55 r.-v. i 57 r. (agost, 1), i reg. 134, f. $214 \mathrm{v}$. (1305, gener, 28).

77 Topònim no identificat.

78 ACA, C, reg. 133, f. 69 r.-v. (1304, agost, 21 ).

79 El fur d'Aragó permetia pasturar el bestiar en els termes de llocs veïns, sempre que a la nit tornés al d'origen: ACA, C, reg. 141, f. 7 v. (1307, agost, 30) i cf. abans la nota 71 , amb bibliografia sobre aquest tema. 
els impedien de fer ${ }^{80}$. El 29 d'agost de 1302 Jaume II encarregà al justícia d'Aragó, Ximèn Pérez de Salanova, i al batlle general d'Aragó, Gil de Jaca, que anessin personalment a Pertusa, visitessin el terme, veiessin els documents i després decidissin sobre els plets pels límits dels termes i l'empriu de llenya i de pastura pels quals aquell lloc s'enfrontava amb els d'Antillón, Ponzano i les Cellas ${ }^{81}$. Poc després encomanà encara al justícia que resolgués un altre plet que enfrontava Pertusa amb Pere de Pomar per l'empriu de llenya i pastura que els de Pertusa afirmaven tenir a Burjamán"2.

L'any 1303 Jaume II confirmà un privilegi concedit per Jaume I el 31 de març de 1263 al lloc de Torres, que era de Guillem de Puig, al d'Albero de Juso (Albero Bajo), que era de dona Jordana, al de Vicién, que era de Fortún de Bergua, i als de Barbués i Pompién, que eren de Sanç d'Orta, els quals podien tallar llenya en els boscos i muntanyes d'Almudévar, de Tardienta, de Torralba, d'Alcubierre i de Robres, llevat dels vedats antics, per a tots els usos domèstics: coure pa i carn, escalfar-se etc., però no per a vendre. No podien tallar pins ni carrascals ni altres arbres prohibits en els furs d'Aragón ${ }^{83}$.

Els veïns d'Alcalà, lloc que pertanyia al monestir de Sixena, es queixaren també l'any 1297 que, des que el lloc de Pina havia pervingut a mans d'Artal d'Alagó, els molestaven en el dret que tenien de tallar llenya menuda i grossa i pasturar el bestiar en el terme de Pina ${ }^{84}$. Una altra possessió del monestir, Candasnos, tenia un plet amb Fraga també pels emprius d'herbatge, talla de llenya i fusta $\mathrm{i}$ «escalis», empriu de conreu eventual al qual ja ens hem referit a l'apartat sobre obtenció d'artigues. L'any 1307, Jaume II hi intervingué per tal que el plet fos resolt per tres àrbitres, que s'havien de reunir amb les parts interessades, és a dir, la priora de Sixena i els veïns de Candasnos d'una banda i Guillem de Montcada, senyor de Fraga, i els homes de Fraga de l'altra, a Candasnos el 22 de setembre de $1307^{85}$. En una comarca tan àrida com la del Baix Cinca és natural que hi hagués tensions per l'aprofitament dels escassos espais boscosos i de pasturatge.

El mateix problema tenien els veïns de Xalamera, lloc que pertanyia a la castellania de Montsó, de l'orde del Temple i que, des d'antic, tenia dret de fer llenya i de pasturar el bestiar al terme d'Ontinyena. L'any 1298 el castellà de Montsó es queixà que els veïns d'aquest darrer lloc colpejaven i insultaven els pastors de Xalamera que acudien al seu terme; malgrat que el rei manà al sobrejunter d'Osca que fes respectar l'empriu, el prior de Santa Maria de Xalamera considerà convenient usar també la pressió eclesiàstica i l'any 1302 demanà al bisbe de Lleida de procedir contra els veïns d'Ontinyena en virtut d'una constitució del concili de Tarragona contra els raptors $\mathrm{i}$ invasors. Els veïns d'Ontinyena recorregueren al rei, el qual declarà que la constitució conciliar no era adequada a aquest cas. ${ }^{86}$

80 ACA, C, reg. 125, ff. 10 v.-11 r. (1302, juliol, 25). El rei repetia un manament que ja havia fet el 13 de juny de $1300 \mathrm{i}$ que no havia estat obeï.

81 ACA, C, reg. 125, f. 44 r. (1302, agost, 29).

82 ACA, C, reg. 126, f. 184 r. (1302, desembre, 21$).$

83 ACA, C, reg. 200, f. 193 r. (1303, mars, 27).

84 Els de Pina volien intervenir també en el nomenament del justícia d'Alcalà: ACA, C, reg. 109, f. 349 r.

85 ACA, C, reg. 141, f. 13 v. (1307, setembre, 5).

86 ACA, C, reg. 110, ff. 61 v. -62 r. i 135 v. $(1298$, abril, 10) i reg. 125, f. 22 r. $(1302$, juliol, 31$)$. 
Sembla que a les valls pirinenques no hi havia d'haver problemes perquè eren més boscoses, però també n'hi havia.

Per exemple, malgrat que els habitants de Gistain o Gistau tenien el dret de tallar llenya, pasturar el bestiar, conrear els camps etc. en els termes de les Artigas, Lorbés, «la Puyes», "Aiguanosa» $\mathrm{i}$ «Biados»", els homes de San Juan hi tallaven llenya, pasturaven bestiar i hi conreaven camps i els molestaven amb violència en llur possessió; per això el rei, a qui arribà la queixa, confià la resolució del plet al sobrejunter de Ribagorça i Sobrarb ${ }^{88}$.

L'any 1302 els homes de Castellar feren arribar llur queixa al rei perquè l'alcaid de Castellón, a la vall de Jasa, els impedia tallar fusta i llenya i pasturar bestiar en el bosc de la muntanya de "Cercellar», al terme de Castellar, tal com ho havien fet sempre ${ }^{89}$. Dos anys abans, els veïns de Bolea s'havien queixat perquè el comanador de l'Hospital, Pero de Ayerbe, els perturbava en el dret que tenien, per privilegi, de tallar llenya i fusta i «escaliar» en els termes i muntanyes d'Aïnsa i de Bestuée. Els mateixos veïns d'Aïnsa es queixaren perque el monestir de Santa Cristina els molestava en el dret que tenien, també per privilegi, d'usar els boscos del port d' "Ivor d'Estunnar»".

A la zona més occidental, propera a Navarra, sabem que també hi havia hagut un plet, l' any 1302, entre Salvatierra i Ansó per l'usdefruit de fer llenya, pasturar el bestiar $\mathrm{i}$ conrear el terme anomenat "Gavauri». Una sentència de Juan Pérez de Arbe, merino de Jaca i Ejea, havia determinat que els veïns de Salvatierra podien usar aquestes terres dins d'uns límits que foren indicats i els d'Ansó foren condemnats a una multa'. El mateix Juan Pérez de Arbe rebé manament del rei d'autoritzar els veïns del Pueyo o de la Real a tallar fusta a les muntanyes veïnes, que necessitaven per a la construcció de llurs cases, llevat del mont de "Ruyca»".

L'any 1300 hi havia hagut un altre plet per l'usdefruit de les muntanyes d'Uncastillo. Segons Rodrigo Ximenis de Narbayes, ell i els homes de Layana tenien ús des d'antic del dret de tallar-hi llenya, fer «escalis» i pasturar-hi el bestiar, però els homes d'Uncastillo havien començat a posar-los impediments sense coneixement de causa. El rei encarregà la solució del plet al sobrejunter d'Osca i Jaca, Pedro d'Ahonés ${ }^{94}$.

A les terres més baixes, frontereres amb Navarra, de la comarca de les Cinco Villas, hi hagué també alguns litigis. Per exemple, Ejea es queixà per l'empriu de tallar llenya que els veïns del Bayo exercien a les muntanyes situades entre Ejea $\mathrm{i}$ Tudela, segons ells il.legalment. A requesta dels veïns d'Ejea, el 20 de setembre de 1297 el rei manà a Pere de Montagut, sobrejunter d'Osca i Jaca, que els protegís,

87 Topònims no identificats.

88 ACA, C, reg. 133, f. 39 r. (1304, juliol, 9).

89 ACA, C, reg. 124, f. 137 v. (1302, maig, 8).

90 ACA, C, reg. 117 , f. 309 v. (1300, juliol, 17).

91 ACA, C, reg. 139, f. 1590 v. (1307, febrer, 13). «Ivor d'Estunnar» potser és Ibón de Estanes, a l'oest de Candanchú i de Somport.

92 ACA, C, reg. 124 , ff. 156 v. -157 r. (1302, maig, 18).

93 ACA, C, reg. 124, f. 159 r. (1302, maig, 19).

94 ACA, C, reg. 117 f. 287 r.-v. (1300, juliol, 7). 
mentre es comprometessin a estar a dret als querellants per aquesta causa". Pocs anys després, pel setembre del 1300, calgué repetir el manament per una nova queixa dels veïns d'Ejea contra els del Bayo, que tallaven llenya i «escaliaven» en llur terme*.

A la mateixa comarca, Luna, Biel i el Frago s'enfrontaren en més d'un plet pels emprius de llenya i pastures en unes terres situades entre tots tres termes els anys 1371 i $1471^{97}$. No pas gaire més lluny, els habitants de Segura i de Salcedillo, que era una aldea del primer lloc, foren autoritzats, l'any 1409, per Ferran López de Luna a tallar a les muntanyes del terme la fusta que necessitessin per a la construcció o reparació de cases, confecció de barrils, bótes etc. Sembla que l'alcaid i els munters que vigilaven els boscos havien mal interpretat alguna ordre anterior i només els forasters tenien prohibit de tallar-hi llenya o fusta per a fer carbó, bigues, cairats etc. $^{98}$.

Situant-nos una mica més al sud, a la vall de l'Ebre i prop de la frontera castellana, trobem una zona boscosa, la de Borja, que fou molt cobejada pels pobles veïns. Ja l'any 1279 els veïns d'aquesta ciutat reberen una ordre reial perquè no impedissin al comanador del Temple d' "Albal» de tallar fusta en llurs muntanyes". Els homes de Magallón es queixaren, l'any 1303, perquè l'alcaid de Borja els impedia l'exercici de llur dret a tallar llenya i fusta $i$ de pasturar el bestiar, sense pagar herbatge, als turons del terme de Borja ${ }^{100}$. L'any 1325 , Jaume II autoritzà Felip Ferrandis de Castre i la seva muller Elionor a fer-hi tallar sis càrregues de llenya per a la seva casa, sempre que residissin a llur lloc de Fréscano ${ }^{101}$, i una concessió semblant fou atorgada pel mateix rei a Marquesa de Saluzzo i al seu marit Pedro de Luna: si residien personalment a llur lloc d'Agón, tenien dret a fer tallar a les muntanyes de Borja cinc càrregues de llenya diàries; tres eren per a la casa i dues per al forn del lloc; si no hi residien, el dret quedava reduït a les dues càrregues diàries per al forn. Es comprensible que els veïns de Borja es resistissin a admetre de grat aquesta mena de concessions que hipotecaven llur propi dret a aprovisionar-se de llenya; els obstacles que hi oposaren i les queixes de Pedro de Luna mogueren el rei Jaume II a manar a Pere de Martorell, batlle general d'Aragó, a anar al terme, inspeccionar-lo i assignar-ne una part a fornir les càrregues de llenya concedides a aquells nobles ${ }^{102}$.

A la serra del Moncayo, que s'estén al sud d'aquestes terres, i que encara ara és una zona boscosa, també s'hi produí algun plet. Aranda rebé un manament reial,

95 ACA, C, reg. 109, f. 348 r. (1297, setembre, 20).

96 ACA, C, reg. 116, f. 125 r.-v. (1300, setembre, 11).

97 F. de MOXÓ, Documentación agraria medieval del Arcbivo municipal de Luna, «Estado actual de los estudios sobre Aragón. Actas de las Terceras Jornadas (1980), II, Saragossa, 1981, pp. 866-868.

98. J.L. ARGUDO PERIZ, J. F.CASABONA SEBASTIÁN, J.J. MORALES GÓMEZ i M.J. PEDRAZA GARCÍA, El sefforio jurisdiccional de Maria de Luna. Un registro de cartas de 1409, «Cuadernos de las Cinco Villasn, 2 (1988), docs. 3 i 4.

99 J. E. MARTÍNEZ FERRANDO, Catálogo de la documentación relativa al antiguo reino de Valencia..., II, Pedro el Grande, doc. 560,

100 ACA, C, reg. 129 , f. 80 v. (1303, setembre, 5).

101 ACA, C, reg. 227 , f. 234 r. (1325, setembre, 29 ).

102 ACA, C, reg. 229, f. 205 r.-v. (1326, novembre, 24). 
l'any 1304, perquè permetés que els homes de Malanquilla tallessin fusta i llenya per a llurs cases i pasturessin els ramats en el terme d'Aranda, tal com ho feien des d'antic i s'havia acordat en una composició entre ambdós llocs, que els veïns d'Aranda no devien respectar ${ }^{103}$.

La vall de l'Ebre és una zona estepària, amb poc bosc. Les notícies sobre discussions per l'empriu de llenya solen coincidir, doncs, amb les escasses clapes boscoses de la regió. Prop de Saragossa, a la banda esquerra de l'Ebre, Tauste impedia que els veïns de Remolinos tallessin llenya per al forn de la població i fusta per a la construcció d'un palau en un paratge anomenat el «Soto de Armenter i de Viana» $\mathrm{i}$, a més, els amenaçava amb destruir una sèquia que portava aigua de l'Ebre $i$ de diversos recs, que recollien aigües pluvials, i amb la qual es regava el terme de Remolinos des de temps immemorial. L'any 1304, el comanador de Grisenic (Grisén), de l'orde de l'Hospital, protestà prop del rei Jaume II perquè, des de la mort de Lope Ferrenc de Luna, Tauste no havia respectat l'empriu que hi posseïen els habitants de Remolinos, que pertanyia a l'orde, i en conseqüència el rei ordenà als jurats $i$ consell de Tauste que compareguessin a la cúria en el terme de tres dies per a informar-lo ${ }^{104}$.

Més avall i a l'altra banda de l'Ebre, els infançons d'Urrea es queixaren al rei Jaume II, l'any 1300, perquè Ximèn de Tovia, fill del difunt Jaime d'Oblites, els posava impediments al dret que tenien de conrear i fer «escalis», fer llenya i pasturar el bestiar a les muntanyes d'Urrea i participar, juntament amb els veïns del lloc, en el nomenament de jurats $\mathrm{i}$ altres oficials locals $\mathrm{i}$ de guardians de les muntanyes ${ }^{105}$.

A l'àrea de Calataiud, hi havia, l'any 1300, un plet pendent davant el justícia d'Aragó entre els homes de Cariñena i Alemán de Gúdar, sobrejunter de Tarassona, sobre el dret de pasturar, tallar llenya etc. en els termes de la vila d'Aguarón ${ }^{106}$. Hi hagué també una reclamació del monestir de Piedra, l'any 1303, pels perjudicis que li causaven alguns que caçaven, pescaven, pasturaven el bestiar i tallaven llenya seca $i$ verda a les seves terres, transgredint els privilegis del monestir ${ }^{107}$. Algunes d'aquestes terres, concretament el lloc de Tiestos, foren venudes pel monestir a Ferran Pérez, fill d'Andrés de Liñán, el qual impedí la continuació de l'usdefruit dels boscos del lloc per les poblacions veïnes, provocant les queixes, durant l'any 1304, dels habitants de Cubel i de Torralba, lloc aquest darrer que pertanyia a l'orde del Sant Sepulcre, i que es queixà, a més, de l'ocupació de part del seu terme pel nou propie$\operatorname{tari}^{108}$.

L'any 1303, els homes del Frasno, aldea de Calataiud, es queixaren perquè l'alcaid de Morata no els autoritzava a tallar llenya seca i pasturar d'era a era en el terme de Morata, tal com ho permetia el fur d'Aragó, llevat del lloc dit «Boalar», on reconeixien que calia pagar. En aquest cas, el rei donà deu dies als de Morata per

103 ACA, C, reg. 131, f. 109 r. (1304, març, 12).

104 ACA, C, reg. 132, f. 124 v. 1304, abril, 5).

105 ACA, C, reg. 116 , ff. 17 v. -18 r. (1300, juliol, 21$)$.

106 ACA, C, reg. 117, f. 8 r. (1300, abril, 28).

107 ACA, C, reg. 126 , f. 235 r. (1303, gener, 18).

108 ACA, C, reg. 131 , ff. 115 v. i 102 v. (1304, març, 7 i 11), respectivament. 
demostrar que els del Frasno no tenien aquest dret, passats els quals, si no ho demostraven, volia que els veïns del Frasno poguessin exercir el dret que reivindicaven $^{109}$. L'any 1304 el prior del convent de Sant Benet de Calataiud, es queixava que els veïns de Villafeliche i de Murero usurpaven part dels termes del monestir de San Salvador de Foz, que aquell convent posseïa per donació del rei Alfons, hi conreaven vinyes $\mathrm{i}$ impedien que el monestir hi entrés els seus ramats i que hi tallés la llenya necessària per al propi consum ${ }^{110}$.

A l'àrea de Daroca, tenim constància de la queixa presentada pel consell de Báguena al rei Pere el Cerimoniós perquè gent d'altres aldees de Daroca tallaven llenya i portaven a pasturar el bestiar gros i menut als boscos i a la devesa o bovalar d'aquest lloc. En aquest cas sembla que tot l'interès dels homes de Báguena era aconseguir que els infractors paguessin la multa estipulada, cosa que el rei Jaume II encomanà a un notari de Burbáguena, anomenat Pedro García ${ }^{111}$.

Més cap al sud, les terres turoleses eren força més riques en boscos, però això no vol dir que hi hagués menys discussions entre les poblacions pels emprius. Per exemple, hi hagué un plet entre els homes de Camarena, aldea de Terol, i la capital perquè els veïns de la ciutat i d'altres aldees tallaven llenya i fusta a les muntanyes del lloc, la serra de Camarena, per enviar-la a València; els veïns de Camarena demanaren la intervenció del rei per evitar la destrucció de les muntanyes, que els hauria perjudicat molt $^{112}$.

Terol també topà l'any $1303 \mathrm{amb}$ un tal Pedro Ortís que sembla que posseïa un lloc dit el "Crabonciello", on els veïns de la ciutat acostumaven a tallar llenya, pasturar el bestiar, usar les aigües i transitar amb carreta pel terme, cosa que Pedro Ortís els impedia llavors ${ }^{113}$. Hi hagué encara un altre enfrontament amb el consell d'Albarrasí, l'any 1305, per delimitació de termes i dret de tallar llenya i el rei en confià la solució al batlle general d'Aragó, Gil de Jaca ${ }^{114}$.

Al mateix temps, Albarrasí, que era una regió de gran riquesa forestal, tenia un altre plet amb el monestir de Piedra, que assegurava que els homes de les granges que posseïa a Villar del Salz tenien empriu de tallar llenya al terme d'Albarrasí, cosa que el consell d'aquesta localitat negava. Jaume II intervingué a favor del monestir de Piedra"s.

Un altre indret amb boscos cobejats era la batllia d'Aliaga, que pertanyia a l'orde de Sant Joan de Jerusalem. El lloc era situat entre la serra de Sant Just al nord i la serra de Gúdar al sud i era banyada pel riu Guadalop. L'any 1307, fra Pere de Soler, castellà d'Amposta, protestà perquè homes de les aldees de Terol hi tallaven fusta i llenya per a ús propi i també per a vendre. Jaume II confià la resolució de la queixa a Sancho Muñoz, jutge de la cúria, i a Pedro de Mora, veïns ambdós de Terol $^{116}$.

109 ACA, C, reg. 129, f. 31 r. (1303, agost, 17).

110 ACA, C, reg. 133, f. 67 r.-v. (1304, agost, 16).

111 ACA, C, reg. 585, f. 8 v. (1336, mars, 7).

112 ACA, C, reg. 117, f. 77 v. (1300, maig, 15).

113 ACA, C, reg. 123, f. 42 r. (1302, mars, 5).

114 ACA, C, reg. 134, f. 233 r.-v. (1305, febrer, 20).

115 ACA, C, reg. 138, ff. 143 v.-144 r. (1306, març,7).

$116 \Lambda C A, C$, reg. 111 v. -112 r. (1307, novembre, 18). 
A la banda septentrional de la serra de Sant Just, a la comarca de Montalbán, que també gaudia de zones boscoses, tenim notícia d'un litigi per l'empriu de llenya en el terme de Huesa entre l'alcaid del castell d'aquest lloc i els veïns de Monforte. Sembla que hi havia hagut una sentència entre l'alcaid $i$ els veïns de Huesa que atorgava a l'alcaid la prerrogativa de demanar herbatge en els boscos i pastures del terme del castell; però els veïns de Monforte l'havien ignorada i havien anat a tallar llenya i fusta al terme d'aquest castell, cosa que l'alcaid considerà un greuge contra els seus drets $\mathrm{i}$ aconseguí un manament del rei que li donava la raó ${ }^{\prime \prime}$.

A la comarca del Matarranya, fronterera amb Catalunya i amb el País Valencià, també hi hagué litigis entre alguns llocs dels ordes militars, malgrat que els boscos $\mathrm{i}$ les pastures hi eren força abundosos. L'orde del Temple hagué de queixar-se, l'any 1303 , de l'orde de Calatrava perquè els homes de la Ginebrosa, domini dels Templers, eren inquietats pels de Mont-roig, de l'orde de Calatrava, en l'empriu de fer llenya, tallar fusta per a llurs necessitats i pasturar el bestiar en el terme de Montroig, empriu que tenien des que el lloc s'havia repoblat ${ }^{118}$. Es comprensible, però, que Mont-roig s'inquietés per tants usufructuaris dels seus boscos, perquè els veïns de la Ginebrosa no eren pas els únics que hi acudien. Fra Garcia López, comanador d'Alcanyís, s'havia queixat l'any 1301 perquè veïns de Morella, contra la voluntat dels veïns de Mont-roig i la seva i contra llurs privilegis, tallaven fusta al terme de Mont-roig i hi pasturaven els ramats ${ }^{119}$.

Aquestes querelles entre poblacions veïnes es convertien en problema d'estat quan entre l'una i l'altra hi havia una frontera. És el que s'esdevingué a la frontera navarro-aragonesa, entre els homes de Monteagudo i els de Tarassona. Segons el governador de Navarra, els de Tarassona havien envaït a mà armada el terme de Monteagudo, quan els homes d'aquest lloc anaven a les muntanyes del rei de Navarra i França a tallar llenya, i n'havien mort un. Segons Jaume II, els de Monteagudo havien injuriat els de Tarassona en llurs muntanyes, però, de tota manera, prometé fer enquesta sobre la qüestió ${ }^{120}$.

\section{Els forns}

Les diferents menes de forns eren també uns consumidors importants de llenya. Entre aquests forns destaquen els de pa i els de calç, que eren presents gairebé a tot arreu perquè eren necessaris per a la manutenció i per a la construcció, i els forns de vidre. No n'hem trobat notícies, però ben segur que eren presents en molts indrets, dels forns de terrissa i dels de pega.

Encara que no feien servir forns, sinó més aviat llars de foc, també cal citar els saboners entre els artesans consumidors de llenya ${ }^{121}$.

Pel que fa als forns de pa, sabem que els anys 1304 i 1305 el jurista barceloní,

117 ACA, C, reg. 250, f. 35 r. (1327, juny, 9).

118 ACA, C, reg. 123, f. 28 r. (1303, febrer, 25).

119 ACA, C, reg. 120 , f. 188 r. (1301, desembre, 29).

120 ACA, C, reg. 122, f. 217 r. (1301, agost, 24).

121 Ibidem, pp. 408-409. 
Bernat Guillem de Vallseca, tingué dificultats per a l'aprovisionament de llenya per al forn de Terrassa, que li pertanyia, probablement per establiment emfitèutic. Sembla que el contracte li concedia el dret de fer llenya i boscar en el bosc de la Garriga, però que Guillem de Viladecavalls i els seus homes amenaçaven els llenyataires que treballaven per a ell $i$ impedien llur tasca. Com que acudí al rei, el monarca ordenà al veguer de Barcelona i Vallès que fes respectar el seu dret de tallar llenya. Suposem, doncs, que la llenya tallada devia ésser molta; altrament, no hauria suscitat tanta reacció en contra ${ }^{122}$.

Ja hem esmentat abans el dret reconegut, l'any 1326, a Marquesa de Saluzzo, al seu marit Pedro de Luna i al lloc d'Agón de tallar dues càrregues diàries de llenya als boscos del terme de Borja destinats al forn del $1 \operatorname{loc}^{123}$, i hem comentat també els impediments posats per la vila de Tauste als veïns de Remolinos, que tallaven llenya per al forn de la població al terme de Tauste ${ }^{124}$.

També devia ésser molt important el consum dels forns de calç per a les grans obres públiques, com les catedrals o les muralles de les ciutats i viles, i per a les obres dels particulars. L'any 1308 hi havia hagut queixes dels obrers de la catedral de València perquè hom els prenia la llenya que havien reunit al terme de la ciutat per als forns de calç de la seu ${ }^{125}$. L'any 1335, Felip de Castre s'assegurà proveïment de llenya per a fer la calç necessària a les obres de reparació que volia efectuar al seu castell de Fréscano. L'infant Pere comunicà al justícia, i als jurats i prohoms de Borja que havia concedit al noble Felip de Castre que pogués fer calç en el terme de la dita vila i que, per tant, els homes d'aquest noble podrien tallar llenya en els boscos de Borja per a fer la calç i endur-se-la després a Fréscano ${ }^{126}$.

L'any 1361 els consellers de Barcelona donaren les màximes facilitats als veïns de Sants, de Sarrià, de Badalona, de Sant Andreu o de qualsevol altra parròquia del territori de Barcelona que fessin calç per a les obres de les muralles de la ciutat. Els autoritzaren a tallar pedra $\mathrm{i}$ jonc on els convingués, pagant-ne al propietari del lloc el preu habitual, però no feren esment de la llenya ${ }^{127}$.

A la darreria del segle, l'any 1399, el rei autoritzà els veïns de Rubielos de la Cerida, aldea de Daroca, a tallar arbres en els boscos reials o en els dels llocs veïns, fins i tot salzes, que habitualment eren prohibits, per tal de fer calç per a les obres de reparació que calia efectuar en el castell del dit lloc, que era en frontera amb Castella; els homes del Rubielos s'havien ofert a fer les obres a llurs despeses i, tant per aquest motiu com perquè es tractava d'una obra defensiva i d'interès públic, és comprensible que el monarca els donés facilitats ${ }^{128}$.

Els forns de vidre, que eren més escassos, s'instal.laven generalment prop dels boscos que els fornien combustible i lluny de les ciutats, ja que els municipis

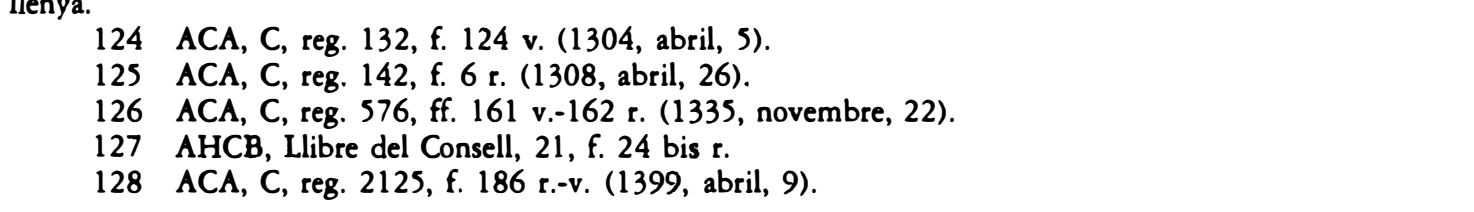


prohibiren sovint que n'hi hagués dins el clos de les muralles perquè representaven un risc d'incendi. Per exemple, Barcelona ho prohibí l'any 1324, bé que més tard l'ordre fou revocada i l'any 1346 un vidrier projectà la construcció d'un nou forn a la ciutat, però sabem que en el segle XV uns vidriers de Barcelona tenien el forn a Bigues. Un forn de vidre podia cremar 8.000 quintars de llenya en sis o set mesos ${ }^{129}$. Hi hagué altres forns de vidre a Sant Fost de Campsentelles, a Montcada, a Granollers, a Mataró, a Vallromanes i a Palau, al Rosselló, lloc anomenat després Palau del Vidre ${ }^{130}$.

\section{La construcció de cases}

La construcció d'edificis exigia una gran quantitat de fusta, de bona qualitat per a bigues, muntants, portes, finestres etc. Les cartes de població, que hem esmentat abans perquè al.ludeixen al dret de fer llenya, sovint també mencionen la fusta, al costat de la llenya, o bé usen els adjectius «seca $i$ verda» per a referir-se a llenya per cremar o fusta per a fer eines, construir etc. La major part de la documentació que acabem de comentar a l'apartat sobre obtenció de llenya per a ús domèstic esmenta la paraula fusta al costat de llenya.

Alguna carta de població, com la de la Pobla de Claramunt, concedida pel vescomte Hug de Cardona l'any 1344, després que la vila quedés destruida per una riuada, menciona de manera molt específica el dret d'agafar pedra i fusta del terme per tal de reedificar les cases derruïdes, cosa comprensible, ateses les circumstàncies $^{131}$. Una altra carta de població, la de Calaceit, concedida per l'orde de Calatrava l'any 1278, donava als veïns el dret de tallar fusta seca i verda al terme, però restringia el dret de vendre-la als forasters, llevat que fos treballada a la vila. Curiosament, l'orde s'incloïa en la prohibició de vendre fusta als forasters; suposem que és un indici que la riquesa forestal de Calaceit no hauria resistit una explotació intensiva $i$ que aquesta limitació era una mesura sàvia per a mantenir-la, sense perjudicar l'activitat dels fusters locals ${ }^{132}$.

Els registres de la cancelleria reial proporcionen notícies sobre llicències per a fer tallades d'arbres en terres del Patrimoni reial per a la construcció d'algun edifici determinat o sobre franquícies de pas per al mateix objectiu; l'any 1282, per exemple, Pere el Gran atorgà llicència de pas a la fusta destinada a la construcció dels convents de framenors d'Alacant i de Múrcia, concedida per l'infant Sanç de Castella, perquè havia de passar per terres valencianes, i Alfons el Franc atorgà franquícia d'impostos a la fusta que els monjos del convent de Sant Agustí d'Alzira necessitaven per a llur edifici ${ }^{133}$.

129 J. GUDIOL RICART, Els vidres catalans, Barcelona, 1936, pp. $32-33$ (Monumenta Cataloniae, III). C. CARRÈre, Barcelona, 1381-1462. Un centro econòmic en època de crisi, pp. 411-415.

130 J. GUDIOL, Els vidres catalans, Pp. 32-33 i 37-41; A. OLIVER CASTA X(OS, El taller de vidre medieval de Sant Fost de Campsentelles, «Acta Historica et Archaeologica Mediaevaliaw, 10 (1989), pp. 387-422.

131 J. M. FONT RIUS, Carbas de población y franquicia de Catalunta, I, cipc. 376.

132 J. MONCLÚS, Una vila medieval entre fronteres, Calaceit al segle XIII, Bar clona, Xarxa Cultural, 1987, pp. $136-146$

133 J. E. MARTÍNEZ FERRANDO, Catálogo de la documentación relativa al reipo de Valencia..., II, Pedro el Grande, doc. 1503; R. GALLOFRÉ, Documentos del reinado de Alfonso III, doc. 713. 
Llicències per a fer tallades també n'hem trobat algunes. Per exemple, el 16 de novembre de 1316 el rei Jaume II comunicà al sobrejunter d'Osca i Jaca i al justícia de la vall d'Hecho que havia concedit al prior i convent de predicadors de la localitat navarresa de Sangüesa una autorització per a tallar durant un any cent pins en els boscos d'Hecho ${ }^{134}$. Pere el Cerimoniós en concedí una altra, l'any 1384 , a Guillem Ponç per a tallar trenta arbres en el bosc reial de Torroella de Montgrí; Guillem Ponç, que havia estat lloctinent del protonotari del rei i era llavors secretari de l'infant Martí, els necessitava per a fer obres a la casa que havia heretat del seu pare a Torroella. Per la raó que fos no utilitzà la llicència tot seguit i, l'any 1389 , quan ja regnava Joan $I$, es trobà amb l'impediment que aquest monarca havia prohibit tallar arbres als boscos i a les deveses de Torroella; calgué, doncs, que Joan I decretés una excepció a favor seu, confirmant la concessió anterior ${ }^{135}$.

El rei Martí, en canvi, hagué de revocar una llicència atorgada per a tallar pins al terme de Morella per a obres seves i d'alguns servidors perquè el monestir de Benifassà protestà, al.legant que el bosc de Tanalla, on hom volia tallar-los, era del monestir $i$ que els pocs pins que hi havia els necessitava per a ús propi ${ }^{136}$.

A les Valls d'Elda i Novelda els arbres útils per a la construcció devien ésser molt escassos, ja que l'any 1384, quan la reina Sibil.la, senyora d'ambdós locs, necessità cent troncs de pi per a fer obres a Cocentaina i a Elda, demanà autorització al marquès de Villena per a tallar-los a Saix, senyoriu d'aquest noble on, segons la petició, n'hi havia molts. D'altra banda, els dotze troncs d'om que necessitava per a jàsseres a les mateixes obres de Cocentaina la reina els demanà a Rodrigo Díez del seu lloc de Cabanes, a tocar de Castalla ${ }^{137}$.

A vegades el rei cedia per a la construcció fusta nova o vella de la que tenia guardada a les drassanes. L'any 1344 cedí quatre necles a un membre de la seva casa, Francesc Bonfill, que les necessitava per a refer la seva casa, que s'enderrocava de vella ${ }^{138}$. L'any 1338 Pere el Cerimoniós cedí un uixer amb dos arbres, quatre antenes i quaranta rems, que ja no fos apte per a navegar, a l'abadessa de Pedralbes per a la construcció del monestir ${ }^{139}$.

\section{La construcció naval}

Era l'ús privilegiat dels boscos i necessitava fusta selecta. Segons l'erudit jesuïta del segle XVI, Pere Gil, hom utilitzava la fusta de roure i la d'alzina, que és molt forta, per a fer les carenes, costelles, timons i barres travesseres; la fusta de pi i de melis s'usava per a fer les posts de banda de fora del vaixell, que tocaven l'aigua; els avets i pins grossos i llargs servien per a fer els arbres; els més prims i drets servien per a fer les antenes; la fusta d'àlber, o arbre blanc, i la de xop, o arbre poll, era usada per

134 ACA, C, reg. 213 , f. 245 r. $(1316$, novembre, 16).

135 ACA, C, reg. 1871 , f. 142 r.-v. (1389, febrer, 24).

136 ACA, C, reg. 2211, f. 47 r. (1401, febrer, 17)

137 ACA, C, reg. 1590, f. 54 r.-v. (1384, setembre S) i f. 54 v. (1384, agost, 29).

138 ACA, C, reg. 876, f. 169 v. (1344, octubre, 7).

139 ACA, C, reg. 864 , f. 99 r. $(1338$, agost, 23$)$. 
a fer obra morta de l'interior del vaixell, que no tocava a l'aigua, ja que és fusta lleugera. La fusta de noguera s'usava per a la part noble de la popa, cambra del capità o de les personalitats que pujaven a bord ${ }^{140}$. C. Carrère hi afegeix la fusta de faig, molt apreciada per a la "paramola», la peça del vaixell on anaven fixats els pals ${ }^{141}$.

A la costa catalana hi havia una gran demanda de fusta per a la construcció d'embarcacions dedicades a la pesca $i$ al transport $i$ per a les armades reials ${ }^{142}$. Malgrat que la fusta no escassejava, sembla que l'almirall i el vice-almirall tenien autoritat per a ordenar la talla dels arbres que fossin necessaris per a les armades reials allà on els semblés; per això, quan el rei Pere el Cerimoniós volgué afavorir alguns dels seus servidors, que tenien terres amb arbres a les zones on solien acudir els proveïdors de les armades reials, els eximí d'aquest empriu. Així ho féu a favor de Jaume de Puig, lloctinent del mestre racional,pel que feia a la seva casa o "domus» d' "Arcanova», al Vallès ${ }^{143}$, i també a favor de Romeu Llull pel que feia a les terres que posseïa a Sant Andreu de Palomar, a Sant Martí de Provençals i a Sants; en aquest cas, a més d'eximir de l'empriu de les armades tots els arbres d'aquestes propietats, la carta reial mencionava en especial determinats arbres de ribera: àlbers, salzes, verns i oms ${ }^{144}$.

Els comptes de reparació o construcció de galeres que s'han conservat, alguns dels quals han estat publicats, permeten seguir, a través dels jornals pagats, tots els passos de la construcció o reparació, des de la tria i tala d'arbres al bosc i del transport a les drassanes fins a les diverses tasques de fusters i mestres d'aixa. En la reparació de la galera "Victòria», l'any 1390, hom usà fusta de roure i d'alzina de diversos llocs del Vallès Oriental: Vallromanes, la Roca i Parets; la d'àlber procedia de Sant Andreu, Vilapicina, Provençana, Santa Coloma i Sant Adrià, és a dir, de les terres del terme de Barcelona immediates als rius Besòs i Llobregat ${ }^{145}$.

La documentació notarial estudiada per $C$. Carrère també confirma aquestes procedències en la fusta que arribava a Barcelona per a la construcció de vaixells comercials: els massissos del Montseny i del Montnegre, el Vallès i la vall del Besòs eren els llocs d'origen més habituals. Però els constructors barcelonins també acudien més lluny: fusta dels Pirineus llenguadocians que baixava per l'Aude fins a Narbona, o de les Cevenes, que feien venir d'Agde o bé dels Pirineus aragonesos, de Gistau i d'Aïnsa, o bé dels Pirineus catalans, d'Organyà, a la vall del Segre, per exemple; d'aquestes darreres procedències solien venir avets per als pals i les antenes i fusta de qualitat per als rems ${ }^{146}$. Aquesta documentació també permet de conèixer

140 J. IGLÉSIES, Pere Gil, S. J. (1551-1622), i la seva Geografia de Catalunya, «Quaderns de Geografiaw, I, 1949, pp. 228-230.

141 C. CARRÈRE, Barcelona 1380-1462. Un centre econdmic en ipoca de crisi, pp. 195-197.

142 Cf. notícies documentals sobre construcció de vaixells a J.M. MADURELL Y MARIMON, Antiguas construcciones de naves (1316-1 740), «Hispanian, XXVIII (1968), pp. 159-196 i 357-392 i especialment els docs. 3, $4,7,8$ i 9.

143 ACA, C, reg. 893 , ff. 84 v. -85 r. (1352, febrer, 22).

144 ACA, C, reg. 923 , ff. 43 v. -44 v. (1372, setembre, 14).

145 J. M. CASAS HOMS, Reparació d'una galera l'any 1390, «Miscelánea de Textos Medievales», 2 (1974), pp. 167-217, especialment pp. 170, 178, 192-194.

146 C. CARRÈRE, Barcelona 1380-1462. Un centre econdmic en ipoca de crisi, I, Pp. 194-195. 
moltes de les condicions posades pels constructors de vaixells: la tria dels arbres a abatre per una persona experta; que fossin de solana, i no d'obaga, perquè la fusta no fos tan amarada etc. ${ }^{147}$.

La documentació de la cancelleria reial i la dels diversos municipis proporciona informació, també, sobre els llocs on hom anava a buscar la fusta necessària per a la construcció naval. Al començament de l'any 1322, per exemple, Pere Messeguer, armer del rei Jaume II, fou enviat per aquest monarca pels llocs marítims i també a Aragó, a Biescas, a Aso i a alguns altres llocs per a fer tallar la fusta necessària per a l'armada destinada a Sardenya. Portava un guiatge i un manament adreçat a barons, cavallers, lleuders etc. perquè li permetessin actuar ${ }^{148}$. La preparació d'una altra armada per a Sardenya, l'any 1392, obligà també a fer una campanya de talla d'arbres escollits per a la fabricació de vaixells ${ }^{149}$.

Els boscos de Calonge eren una de les zones apropiades per a proveir la construcció naval. L'any 1343 hi hagué un petit incident entre els consellers de Barcelona i el batlle de Palamós perquè Miquel Domingo, ciutadà de Barcelona, amb tres ciutadans més, havia tallat fusta en un bosc prop de Calonge, amb el consentiment de l'amo del bosc per portar-la a Barcelona, on havia de servir per a fer un lleny. L'havien de transportar les barques de Domingo Miquel, de G. Arenós i de P. Rafart. Aconseguiren un albarà de treta del batlle de Calonge, però el batlle de Palamós prengué les barques, els barquers i la fusta perquè no portaven albarà seu. Els consellers de Barcelona exigiren que els barquers fossin deslliurats i demanaren la intercessió del conseller i vice-canceller del rei, Arnau Samorera, prop del batlle de Palamós perquè deslliurés els barquers, que eren gent pobra, carregada de fills ${ }^{150}$.

L'any 1390 la fusta necessària per a fer galeres per a vigilar la mar a València havia de provenir de la banda d'Albarrasí. Una societat formada pels mercaders Guillem Salat, Bernat Llorenç i Vicenç Salat se n'havia d'encarregar. Tant ells com la fusta que havien de fer baixar pel Guadalaviar foren posats sota guiatge del rei $^{113}$.

A vegades alguns elements per als vaixells foren buscats molt lluny. L'any 1379, per exemple, Pere el Cerimoniós envià el mercader Simon Tanyana i un mestre de ballestes anomenat Pere Sabet a Senj, a la costa dàlmata, per a comprar arbres i antenes de galeres, rems i fusta de ballestes per a la seva cort i recomanà ambdós homes al dux de Venècia ${ }^{152}$. Joan I insistí, anys després, el 1390 , en aquesta mateixa direcció i hi tornà a enviar el mateix Simon Tanyana i Ramon Jover. El rei afirmava que a les seves terres hi havia indigència de fusta per a arbres, antenes, rems $i$ ballestes i que, en canvi, n'hi havia en abundància en el districte del dux; per això li

147 lbidem, pp.197-198.

148 ACA, C, reg. 246, f. 334 r. (1322, gener, 10).

149 ACA, C, reg. 1880 , f. 193 v. (1392, novmbre, 9). Anteriorment, l'any 1389, Joan I també havia encarregat la tala d'arbres per a fer vaixells a València: reg. 1843, ff. 78 r.- 79 r. (1389, febrer, 17), ho comentem a l'apartat sobre el transport de fusta pel Guadalaviar.

150 AHCB, Llibre del Consell, 16, f. 62 v. (1343, juliol, 30)

151 ACA, C, reg. 1897, ff. 189 v.-190 r. (1390, febrer, 17).Cf. més endavant la nota 206.

152 ACA, C, reg. 1264, f. 63 .v. (1379, març, 1). 
demanà permís per a exportar-ne amb vaixells venecians. Azzo Trevisan i Jacopo Regugio s'havien d'encarregar de presentar la carta al dux i instar aquesta qüestió per a obtenir una resolució favorable ${ }^{133}$. Encara l'any 1429 uns mercaders barcelonins feren venir de Senj trenta pals per a vaixell ${ }^{194}$.

Cal dir que hi havia un control sobre el destí del vaixell que hom pretenia construir amb la fusta tallada als boscos de la Corona catalano-aragonesa i, si aquest destí no era clar, la treta de fusta podia quedar anul.lada. És el que s'esdevingué l'any $1316 \mathrm{amb}$ la fusta que Guillem de Voltre, mercader i ciutadà de Mallorca, feia tallar als boscos dels bisbats de Barcelona i de Girona, amb llicència reial, per a construir una coca de dues cobertes a Mallorca. Però durant el mes d'agost Jaume II sabé que aquesta coca era per al rei de Tremissèn. El control de la fusta es feia precisament perquè no anés a països islàmics, que en tenien una gran mancança, i servís per a enfortir llur marina, que era sempre una amenaça real o potencial per als països cristians. Jaume II revocà, doncs, la llicència de treta de fusta, llevat que el propietari jurés que no vendria la coca ni cap més vaixell al rei de Tremissèn o a cap més rei musulmà ${ }^{1 s s}$.

\section{Altres usos}

L'any 1336, Pere el Cerimoniós prohibí la talla de teixos i d'alguns altres arbres a Montserrat, que els habitants de la muntanya, propietat del monestir, intentaven usar per a fabricar ballestes. El rei manà al prior de Montserrat que en prohibís la tala, llevat que tinguessin una llicència. En aquest cas, el rei no indica cap raó per a la prohibició, com la importància que aquests arbres poguessin tenir per a la indústria naval, llevat de la seva voluntat d'evitar la destrucció del bosc de Montserrat ${ }^{136}$.

\section{Comers interior $i$ exportació de fusta}

Tant el comerç interior de fusta com l'exportació, amb més motiu, eren subjectes a control. La fusta entrava dins de la categoria de les mercaderies d'extracció vedada $i$, per tant, es trobava subjecta al règim de llicència de treta, que implicava demanar permís per a treure-la d'un lloc, on calia presentar després l'albarà d'entrada en el lloc de destinació. Les llicències tenien una durada variable, de quatre mesos a un any, anaven adreçades a una autoritat local, al batlle general de València, al batlle de Tortosa, al de Barcelona etc. Sovint, ho veurem pels concessionaris, servien per a recompensar algun domèstic del monarca $i$, en algun cas, foren utilitzades, fins i tot, com una manera de fer almoina' ${ }^{197}$.

Vet aquí algunes de les llicències que hem trobat:

154 C. CARRÈRE, Barcelona 1380-1462. Un centre econdmic en ipoca de crisi, I, pp. 194-195.

155 ACA, C, reg. 243 , ff. 147 v. -148 r. (1316, agost, 16).

156 ACA, C, reg. 1052, f. 11 r.-v. (1336, febrer, 18).

157 ACA, C, reg. 864, ff. 53 r. i 78 r. (1338, juny, 7 i juliol, 23). 
Any

$1296.6 .19^{198}$
$1303.5 .15^{159}$
$1304.4 .9^{160}$
$1304.12 .24^{161}$
$1304.12 .26^{162}$
$1305.1 .19^{163}$
$1305.2 .10^{164}$
$1305.7 .28^{169}$
$1310.3 .28^{166}$
$1326.1 .2^{167}$
$1326.2 .2^{168}$
$1326.4 .20^{169}$
$1326.7 .8^{170}$
$1326.9 .6^{171}$
$1326.12 .10^{172}$
$1336.7 .21^{173}$
$1338.6 .7^{174}$

Concessionari

Bernat Ferrer, canviador de València

Guillem Gallifa, sobrecoc del rei Pere de Montmeló ciutadà Barcelona Pere Saragossa veí d'Alpont Berenguer de Sant Joan

Pere de Claperes ciutadà Valéncia Enric de Quintavall, cavaller

Arnau Romaní, de l'orde del'Hospital Miquel Carreter, veí d'Alzira

Bernat Pagès, de la cambra reina Guillen de Barberà

Guillem de Palau cavaller

Guillem i Pere Pellicer, de Vilafranca

Pere Robert porter del rei Jaume Veguer ciutadà Barcelona Mateu de Montblanc ciutadà Tortosa Joan Pere de Novals ciutadà Tortosa
Llocs d'origen

i destinació

R.Valencia-

Genova

R. València-

on vulgui

Barcelona-

on vulgui

R.València-

on vulgui

R.Valéncia-

Barcelona

R.València-

on vulgui

R.València-

on vulgui

R.Valéncia-

on vulgui

Villaluenga-altres

llocs regnes

Sevilla o

Mallorca

R.València-Cubelles o Caulers

R.València-Roses

R.València-Sitges

R.València-

on vulgui

Barcelona-Gerba

Tortosa-Mallorca

València-on vulgui
Classe de fusta

i quantitat

1000 fusts

1000 fusts/do-

bleres/tirants

1000 cairats

500 tirants/

dobleres

300 fusts

1000 fusts

1500 fusts

100 fusts

1000 pins

600 fusts

24 carretals

80 necles/

dobleres/

50 fusts

500 dobleres

40 carretals

1000 pins

carretals

158 ACA, C, reg. 340 , f. 155 v. (1296, juny, 19).

159 ACA, C, reg. 200, f. 223 v. -224 r.

160 ACA, C, reg. 202 , f. 224 v.

161 ACA, C, reg. 202, f. 200 r.

162 ACA, C, reg. 202, f. 198 r.

163 ACA, C, reg. 202, f. 205 r.

164 ACA, C, reg. 202, f. 213 r.

165 ACA, C, reg. 203, f. 51 v.

166 ACA, C, reg. 206, ff. 105 v. -106 r.

167 ACA, C, reg. 228, f. 126 r.-v.

168 ACA, C, reg. 228 f. 20 r.

$169 \Lambda \mathrm{CA}, \mathrm{C}$, reg. 228, f. 90 r.

170 ACA, C, reg. 229, f. 157 r.

171 ACA, C, reg. 229, f. 181 r.-v.

172 ACA, C, reg. $229 \mathrm{ff} .216 \mathrm{v} .-217$ r.

173 ACA, C, reg. 859, f. 202 v.

174 ACA, C, reg. 872, f. 54 r. 


\begin{tabular}{|c|c|c|c|}
\hline Any & Concessionari & $\begin{array}{l}\text { Llocs d'origen } \\
\text { i destinació }\end{array}$ & $\begin{array}{l}\text { Classe de fusta } \\
\text { i quantitat }\end{array}$ \\
\hline $1341.8 .4^{175}$ & $\begin{array}{l}\text { Joan de Sant Pau } \\
\text { comprador reina }\end{array}$ & $\begin{array}{l}\text { d'on vulgui menys } \\
\text { R. València-on vulgui }\end{array}$ & 1000 fusts \\
\hline $1351.2 .28^{176}$ & $\begin{array}{l}\text { Bonanat Descoll } \\
\text { vicealmirall de } \\
\text { Catalunya }\end{array}$ & $\begin{array}{l}\text { R.Valéncia- } \\
\text { Barcelona }\end{array}$ & $\begin{array}{l}100 \text { trabes/ } \\
\text { tirants/ } \\
\text { carretals }\end{array}$ \\
\hline
\end{tabular}

A vegades es presentaven dificultats en l'execució de les llicències, especialment pel que feia a la seva durada. Per exemple, el sobrecoc del rei Jaume II, Guillem Gallifa, a qui el 15 de maig de 1303 havia estat concedida una llicència de treta de fusta de València, vàlida per un any, demanà el 6 d'abril de 1304 una pròrroga perquè el mercader a qui havia encomanat la treta de la fusta no se n'havia ocupat i l'havia hagut de substituir per un altre; però el 30 de novembre del mateix any encara no l'havia pogut treure tota, raó per la qual demanà la renovació de la llicència ${ }^{17}$. Un cas semblant fou el d'Enric de Quintavall, a qui havia estat concedida una llicència el 10 de febrer de 1305, per treure 1500 fusts del regne de València en el termini d'un any; el 12 d'abril de 1306 només n'havia tret 200 i obtingué una pròrroga d'un any per treure la resta ${ }^{18}$.

En algun cas el termini fou prorrogat abans que caduqués, quan l'interessat s'adonava que no el podria complir; s'esdevingué així amb la llicència atorgada el 19 de gener de 1305 per sis mesos a Pere de Claperes, que fou prorrogada fins a la festa de Sant Miquel el 22 de maig del mateix any ${ }^{179}$. Un cas semblant fou el de Bernat Pagès, de la cambra de la reina Elisenda, que havia obtingut una llicència el 12 de setembre de 1325 per portar 600 fustes a Sevilla o a Mallorca. La llicència era vàlida per sis mesos, però com que pel gener de 1326 no devia preveure poder realitzar aquesta exportació en el temps concedit, demanà una pròrroga del termini; li fou atorgada per un any, però encara hagué de demanar una nova pròrroga pel juny de $1326^{180}$.

Calia complir també uns terminis pel que feia al lliurament en el port de sortida de l'albarà que certificava que la fusta havia estat desembarcada en el lloc autoritzat. El ciutadà de València Arnau Safranquesa havia obtingut llicència del batlle general del regne per treure'n 100 dobleres de fusta per portar a Mallorca i, com era habitual, es comprometé a portar dins d'un cert termini un albarà del batlle de Mallorca conformament la fusta s'hi havia descarregat. Però Arnau Safranquesa morí $i$ els hereus no pogueren complir aquesta exigència en el termini prefixat. Per tal d'evitar la multa en la qual havien incorregut demanaren la intervenció del rei, que l'any 1326 adreçà un manament a Bernat Sanou, batlle general de València,

175 ACA, C, reg. 872, f. 54 r.

176 ACA, C, reg. 892, f. 158 v.

177 ACA, C, reg. 202, ff. 125 i 181

178 ACA, C, reg. 202, f. 213 r. i reg. 203 , f. 144 r.

179 ACA, C, reg. 202, f. 205 r.

180 АCA, C, reg. 228, f. 126 r.-v. (1326, gener, 2) i reg. 229, f. 126 r.-v. 
perquè no fes cap empara per aquesta causa si li portaven l'albarà del batlle de Mallorca, encara que fos fora de temps ${ }^{181}$.

Guillem Mas, de Barcelona, també n'havia obtingut una per portar 40 dobleres de València a Barcelona. S'esdevingué, però, que Bernat de Fonollar, que les necessitava, les féu descarregar a Sitges i per tant Guillem Mas, que no podia presentar l'albarà de Barcelona, sol.licità la intervenció del rei prop del batlle reial de València pel juliol de $1326^{182}$. El mateix any el rei hagué d'intercedir encara per Guillem Maimó, de Blanes, que es trobava en un cas semblant, ja que havia tret de València 15 necles per portar-les a Sant Feliu però, quan el lleny arribà a Blanes, Bernat de Cabrera es quedà la fusta per al seu castell de Montpalau i per tant Guillem Maimó no pogué obtenir l'albarà de descàrrega de Sant Feliu i temia que el batlle general de València no procedís contra ell $\mathrm{i}$ els seus fiadors ${ }^{183}$.

La fusta que s'exportava sortia majoritàriament de València i provenia d'Aragó, de la zona d'Albarrasí, o bé de Castella. Per Tortosa sortia la que baixava per l'Ebre.

Els habitants de la ciutat de València se solien proveir a Albarrasí, bé que alguna vegada hi hagué controvèrsies entre ambdós municipis que, almenys l'any 1389, acabaren en un decret de represàlies d'Albarrasí contra València. Per això uns mercaders valencians, que havien comprat una quantitat de pins a les deveses de Ferran López de Heredia i d'altres propietaris del terme d'Albarrasí, demanaren la intervenció del rei Joan I prop de les autoritats municipals d'aquesta vila a fi que no els penyoressin quan traguessin els pins ${ }^{184}$.

Els barcelonins se solien proveir de llenya i fusta al Maresme i als altres llocs veïns. A Mataró estaven exempts de l'impost sobre la fusta, malgrat que a vegades Guillem de Sant Vicenç no respectava aquesta franquícia, tal com s'esdevingué l'any $1326^{185}$.

La fusta necessària per a la construcció del pont de Sant Boi, però, volien treure-la del regne de Mallorca, no pas de les Illes, sinó més aviat del Rosselló o de la Cerdanya. Per això els consellers de Barcelona demanaren autorització al rei de Mallorca perquè Guillem Adroer la'n pogués treure, ja que a les seves terres anava a més bon preu. Aprofitaren l'ocasió per recordar al rei que els havia promès 100 lliures per a la construcció d'aquest pont i que encara en quedaven 50 per pagar; li demanaren, doncs, que les fes efectives llavors ${ }^{106}$.

\section{Transport de la fusta}

La situació dels boscos exigia normalment un transport combinat terrestre i

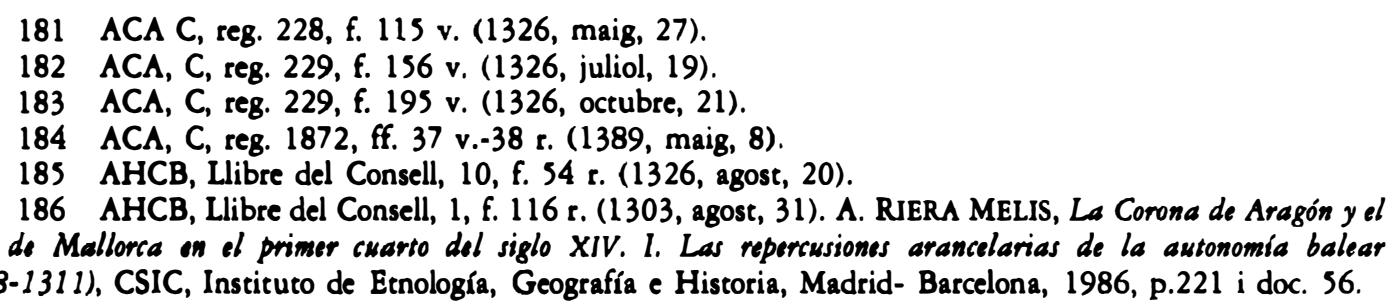


fluvial o terrestre i marítim o, sovint, terrestre, fluvial i marítim, quan es tractava de fusta procedent del terme d'Albarrasí o de Castella i destinada a Catalunya. El transport marítim, combinat amb un breu transport terrestre, era l'usat habitualment per a portar a Barcelona la fusta tallada als boscos de la cadena pre-litoral catalana, que era embarcada en llenys a Mataró, a Llavaneres, a Caldes, a Blanes, etc. ${ }^{187}$.

\section{Transport fluvial}

La fusta era tallada generalment en zones muntanyenques, als Pirineus aragonesos o catalans, o bé a les muntanyes turoleses; per portar-la cap a la plana i especialment cap a la costa mediterrània no hi havia cap altre mitjà de transport millor ni més econòmic que els cursos d'aigua, per on els troncs baixaven agrupats formant rais, si el corrent del riu era suau. Quan els rius discorrien per terrenys muntanyosos i les aigües eren turbulentes, calia aconduir els troncs amb perxes des de la riba, cosa que habitualment causava perjudicis als propietaris de terres a tocar del riu ${ }^{188}$. Els conductors de fusta reivindicaven el dret a tallar arbres de les voreres dels rius, suposem que per à fabricar noves perxes, que es trencaven sovint quan els troncs s'embarrancaven; també reivindicaven el dret d'obrir i adobar passos per la ribera per tal que els homes i les cavalleries que aconduien la fusta poguessin circular; tot plegat produia tensions amb els propietaris de terres de tocar dels rius $^{189}$.

En contraposició a la seva economia, el transport fluvial tenia, doncs, alguns inconvenients $i$ aspectes conflictius: els que acabem de mencionar $i$ els que veurem en casos concrets esdevinguts als rius forestals. En síntesi podríem dir que el pas de la fusta causava desperfectes a la xarxa d'assuts i sèquies dels diversos rius, impedia que els molins poguessin treballar etc., coses totes que originaven conflictes amb les poblacions situades al costat dels rius, demandes d'indemnitzacions etc.

La fusta, a més, era objecte sovint de robatoris o de retencions en el seu recorregut per tal d'obtenir-ne peatges, especialment. Suposem també que els troncs es devien esgarriar facilment i que, per això, les Corts de València de 1403 s'ocuparen de la qüestió i disposaren que les fustes i els troncs que baixessin pels rius i rambles, que no tinguessin senyals d'haver estat tallats o aparellats i no tinguessin propietari, serien de qui els trobés. En canvi, si tenien senyals d'haver estat tallats i preparats per a alguna obra, la troballa havia d'ésser notificada als oficials reials en el termini de tres dies. Les fustes d'assuts i de rescloses havien d'ésser tornades als propietaris $^{190}$.

L'Ebre i els seus afluents.- La fusta tallada als Pirineus aragonesos o catalans, o

187 J. M. MADUREll, Antiguas construcciones de naves (1316- 1740), doc. 8.

188 F. CARRERAS Y CANDI, La navegación en el río Ebro. Notas bistóricas, Barcelona, 1940, p. 154.

189 Cf. més endavant la nota 203.

190 R. GALlOFRÉ, Documentos del reinado de Alfonso III, doc. 2044; ACA, C, reg. 2322, f. 126 v. (1403, setembre, 28). 
bé a les muntanyes turoleses, baixava pels afluents de l'Ebre i després Ebre avall fins a Tortosa. Sovint, però, la baixada de la fusta topava amb dificultats per l'acció de nobles o de municipis que tenien jurisdicció en llocs de pas o per robatoris.

Entre els robatoris podem mencionar, per exemple, el cas que fou denunciat per Domingo Pérez de Molinos, que pel novembre de l'any 1300 acusà Ramon de Monesma, Domingo Ferrís i altres veïns d'Alcanyís d'haver-li pres del riu Guadalop una partida de fusta que hi feia baixar ${ }^{191}$.

Al final del segle, un veí de Tarassona, Martín Fernández de Córdoba, es queixà al rei perquè alguns moros li havien robat les seves set balses o almadies de fusta prop de Mequinensa, quan les feia baixar per l'Ebre per tal de vendre-les a Tortosa. El rei manà al veguer $i$ als altres oficials d'aquesta ciutat que fessin una enquesta sobre aquesta qüestió i procedissin en justícia ${ }^{192}$.

Entre els nobles que posaren impediments al pas de la fusta cal esmentar Guillem d'Entença. Pel maig de 1315 Jaume II li comunicà que el seu lleuder a Mequinensa havia retingut pel valor de la lleuda una part de la fusta que feia venir de Bielsa a Tortosa baixant pel riu i li manà que la fes restituir ${ }^{193}$. Però G. d'Entença es permeté esmenar el rei, assegurant que la fusta que havia retingut no venia de Bielsa. El mes d'agost, el rei reconegué l'error contingut a la seva carta, ja que, efectivament, no procedia de Bielsa, sinó de Jaca i, baixant per l'Ebre, havia passat per Navarra que, suposem, devia ésser el motiu al.legat pel noble per a exigir la lleuda. La carta de Guillem d'Entença devia ésser força impertinent perquè el rei es dolgué que l'acusés d'haver escrit alguna cosa contrària a la veritat per suggestió d'algú i li demanà que lliurés la fusta al portador de la carta sense pagar lleuda ${ }^{194}$. La petició reial no tingué gaire èxit perquè pel desembre Jaume II li escriví indignat perquè havia venut $i$ continuava venent fustes que pertanyien a la cort $i$ que eren a Casp. Impedia que els oficials reials accedissin al lloc on tenia ben bé 200 d'aquests troncs i n'amagava alguns al seu lloc de Garcia. El rei li manà que els restituís $i$ l'amenaçà amb prendre-li penyores per aquest valor, si no ho feia ${ }^{195}$.

Tal com ho acabem d'esmentar, la fusta de les muntanyes de Jaca baixava pel riu Aragón que, abans de desembocar a l'Ebre, entrava a Navarra. Aquest fet complicava el transport, perquè a vegades els navarresos posaven dificultats a la circulació de la fusta pel riu. L'any 1398 Martí l'Humà presentà una queixa a la reina Elionor de Navarra perquè no havia estat respectada la concessió feta pel seu marit a Pedro Ximénez de Aztor, senyor del lloc d'Ixós, i a alguns altres habitants de les muntanyes de Jaca, damnificats per navarresos, perquè poguessin fer baixar fusta per l'Aragón i per l'Ebre, mentre paguessin el peatge i les altres exaccions en els llocs acostumats $i$ indemnitzessin els desperfectes que els troncs causessin en els "artals», castells d'aigües o ports. Confiats en aquesta concessió, els damnificats tallaren fusta i els troncs més grossos els posaren al riu Aragón. Pedro Ximénez de Aztor seguí la

191 El rei manà al sobrejunter de Saragossa que fes restituir la fusta: ACA, C, reg. 116, f. 221 v. (1300, novembre, 6).

192 ACA, C, reg. 1874 , ff. 191 v. -192 v. (1390, abril, 18).

193 ACA, C, reg. 242 , f. 149 r. (1315, maig, 19).

194 ACA, C, reg. 242, f. 203 r. (1315, agost, 5).

195 ACA, C, reg. 243 , f. 9 v. (1315, novembre, 18). 
cabanya de fusta fins al castell de Gallipienzo, on l'alcaid i els homes de la població, a mà armada, atacaren el dit Pedro i els seus acompanyants i els prengueren la fusta. Malgrat les reclamacions dels damnificats, no solament no aconseguiren que els fos retornada sinó que, amenaçats per alguns nobles navarresos, propietaris dels «artals», hagueren de sortir del regne de Navarra. El rei Martí, doncs, demanà justícia per als damnificats i llibertat de circulació per a la fusta o les altres mercaderies que els seus súbdits portessin pel riu Aragón i per l'Ebre, pagant els impostos establerts ${ }^{1 \%}$.

La fusta que baixava pel riu Gállego es trobà amb dificultats a Saragossa. Els assuters que tenien cura dels assuts del raval i d'altres llocs de Saragossa impedien que la fusta que baixava pel Gállego passés al riu Ebre, sembla que amb el pretext que el pas dels troncs feia malbé els assuts. El rei manà al salmedina de Saragossa, el 12 d'agost de 1318, que manés als assuters que no impedissin el pas de la fusta, ja que era una cosa d'utilitat per tota la terra, sempre que els propietaris dels troncs paguessin els danys ocasionats en els assuts ${ }^{197}$. Es possible que el rei resultés afectat també per l'actitud dels assuters de Saragossa perquè el mateix mes d'agost de 1318 hagué de demanar al justícia de Saragossa, Ximèn Pérez de Salanova, que eliminés els obstacles que impedien la lliure circulació de la fusta que feia baixar pel Gállego el seu armer, Pere Messeguer ${ }^{198}$.

Calia comptar, també, amb les dificultats naturals. La fusta que baixava pel riu Noguera Ribagorçana trobava més avall del castell de Montfort, situat entre Tragó de Noguera i Andaní, a la Llitera, un pas estret, tortuós i agrest, amb roques i pedres al mig del llit del riu. L'aigua hi circulava amb molta força i els troncs no hi podien passar. Aquesta situació perjudicava el rei, que no podia treure rendiment del bosc de Cenet, al port de Benasc, ja que la Noguera Ribagorçana era l'únic camí de sortida. Per això el batlle general de Catalunya establí el riu en emfiteusi, l'any 1419, a un mercader lleidatà, Jaume Pere Mercader, que es comprometé a condicionar aquell pas a fi que els troncs hi poguessin baixar. A canvi, fou autoritzat a rebre un peatge o delme de tots els troncs que baixessin pel riu, és a dir, de cada deu un; la quarta part del delme, però, havia d'ésser per al rei, que cobrà, a més, 44 sous per l'establiment ${ }^{199}$.

El Millars.- Bé que era una via menor, comparada amb la de l'Ebre i amb les del Guadalaviar i Xúquer, que esmentarem seguidament, no deixava de tenir importància. L'hem trobada mencionda rarament, potser perquè no s'hi produïen conflictes. Una de les rares mencions té la causa en unes inundacions que hi hagué al País Valencià l'any 1406. Els aiguats arrossegaren riu avall molta fusta i troncs d'arbre, que arribaren a la desembocadura sense que ningú els reclamés. Atès que la fusta $\mathrm{i}$ tots altres béns sense amo eren adjudicats al rei, Martí l'Humà ordenà a un tal Arnau del Bosc que anés a Borriana i Almassora, recollís tota la fusta i els troncs

196 ACA, C, reg. 2116 , ff. 20 r.-21 r. (1398, febrer, 23).

197 ACA, C, reg. 245 , ff. 8 v. -9 r. $(1318$, agost, 12).

198 ACA, C, reg. 245, f. 5 r.-v. (1318, agost, 5). El mes d'agost de 1320 el mateix Pere Messeguer encara feia baixar fusta pel Gállego: reg. 246, f. 90 r. (1320, agost, 18).

199 ACA, RP, MR, reg. 1039, f. 73 r.-v. (1419, maig, 29).

200 ACA, C, reg. 2234 , f. 160 r. (1406, novembre, 27$)$. 
abandonats a la riba dels rius i a mar i ho fes portar tot al grau de València ${ }^{200}$.

El Guadalaviar.- Un altre gran camí forestal era el Guadalaviar o Túria, per on baixava la fusta de la regió d'Albarrasí cap a la ciutat de València. A Castella, a Moya, també podia recollir fusta castellana destinada a València. En efecte, el riu naixia a Aragó, canviava després d'estat i entrava en el regne de Castella, des d'on tornava a terres de la Corona catalano-aragonesa, al País Valencià, on desembocava. Aquest recorregut internacional complicava força el transport de la fusta, tal com ho veurem.

Com a les altres vies fluvials, també en aquesta es produirren casos de robatoris: alguns homes d'Ademús, per exemple, després de vendre una partida de troncs a Sanç Pérez de Luna i a Pasqual Destorrents i de cobrar el transport pel riu, se l'apropiaren, aprofitant-se d'un guiatge que el rei havia concedit âls homes d'Ademús $^{201}$. Els homes de Terol $\mathrm{i}$ de les seves aldees també es queixaren dels robatoris de què era objecte la fusta que enviaven riu avall cap a València en els llocs de la vora del Guadalaviar i, per això, el monarca posà sota la seva protecció els conductors de fusta ${ }^{202}$.

Els perjudicis que el pas de les cabanes de fusta causaven en els assuts i les sèquies igual com als marges eren motiu també de tensions entre les poblacions riberenques dels rius forestals i els tractants de fusta. L'any 1391, dos mercaders de València, Lluís Fonollosa i Bernat Llorenç, afirmaven que tots els rius i les riberes eren públics i d'ús comú, que tothom hi podia transportar mercaderies, amb l'única obligació d'esmenar els perjudicis que es fessin tot passant i que, a les riberes, hom podia tallar arbres $\mathrm{i}$ arrels $\mathrm{i}$ adobar passos. Cal tenir en compte, en efecte, que les almadies, que podien ésser conduïdes des de la mateixa superfície dels troncs, només podien formar-se quan el corrent del riu era suau, tal com ja ho hem dit abans, i que en en els trams de muntanya calia aconduir els troncs amb perxes des de la riba. Suposem, doncs, que la reivindicació del dret de tallar arbres als marges responia a la necessitat de fer perxes, que es trencaven sovint, mentre que la segona reivindicació, la d'obrir i adobar passos, era necessària perquè els homes $\mathrm{i}$ les cavalleries que aconduien la fusta poguessin circular. Així, doncs, les tensions amb els propietaris eren lògiques $\mathrm{i}$ alguna vegada, com en el cas que comentem de Lluís Fonollosa $\mathrm{i}$ Bernat Llorenç, desembocaren en la prohibició de deixar passar la fusta i en l'exigència d'una indemnització pels danys causats, pel temps que els molins havien de deixar de moldre quan la fusta passava pels assuts etc. A petició d'aquells mercaders, el rei hi intervingué per manar que no fossin posats impediments a la circulació de la fusta, mentre reparessin els danys en els assuts ${ }^{203}$.

Lluís Fonollosa i Bernat Llorenç havien comprat al Consell d'Albarrasí el dret de tallar 10.000 pins, una partida molt important que explica que fossin tan exigents; reivindicaren, a més, que el Consell els proporcionés camí per a poder transportar la fusta des del lloc on era tallada; aquest camí hauria de passar per

201 ACA, C, reg. 106, f. 135 v. (1297, desembre, 12).

202 ACA, C, reg. 203, f. 126 r. (1306, mars, 7).

203 ACA, C, reg. 1847, f. 125 r.-v. (1391, febrer, 27). 
on als compradors els semblaria millor, encara que calgués travessar penyes, deveses, terres llaurades o sembrades, bovalars, tancats etc., amb el benentès que els compradors haurien d'esmenar els danys causats en els assuts i les terres a parer de dos prohoms, escollits l'un pel Consell i l'altre pels compradors. Segons ambdós mercaders aquestes eren les condicions del contracte de venda i es queixaren al rei que el Consell d'Albarrasí no el respectava, cosa que motivà una nova intervenció reial a llur favor ${ }^{204}$.

Però el problema principal era la cobdícia que tanta fusta baixant pel riu provocava entre els qui tenien jurisdicció als llocs situats a la ribera, ja que en volien treure algun profit. Ja hem dit que l'any 1268 el rei Jaume I havia concedit franquícia als habitants del regne de València per a tallar llenya on volguessin $i$ traslladar-la sense pagar lleuda ni peatge pels rius Guadalaviar i Xúquer i per qualsevol altre camínios; però, si per la banda del rei la concessió podia ésser respectada, no era tan facil que ho fessin els particulars. Les dificultats començaven en el mateix lloc d'origen de la fusta. L'any 1390 Joan I amonestà els alcaldes i Consell d'Albarrasí perquè no deixaven sortir de llur territori la fusta que el rei hi feia tallar per a fer galeres i altra mena de vaixells a València, sense pagar una quantitat molt important de diners, malgrat que els mercaders valencians, a qui el monarca havia encomanat aquesta tasca, portaven un guiatge reial que els emparava a ells, els seus treballadors, la fusta, l'equip, etc. i que, en virtut de les franquícies de què gaudien els ciutadans de València, no havien de pagar lleudes, peatges ni passatges de cap mena, ni del rei ni de senyors, sempre que paguessin els desperfectes causats pels rais en els assuts $i$ les sèquies ${ }^{206}$.

Les dificultats continuaven gairebé a tots els llocs de senyoriu del recorregut de la fusta. Els homes de Terol, per exemple, es queixaren, l'any 1305, perquè Jaume de Xèrica $\mathrm{i}$ altres cavallers demanaven un peatge per la fusta que passava per llurs termes, contravenint llurs franquícies ${ }^{207}$.

L'any 1317 era el noble Ramon de Riusec qui exigia un peatge que alguns afirmaven que no era acostumat. Els cavallers i prohoms de Moya se'n queixaren i la ciutat de València demandà Ramon de Riusec per aquesta causa ${ }^{208}$, però aquest noble sol.licità la protecció dels oficials reials i del mateix rei per raó de l'evicció a la qual la Corona li estava obligada pel canvi que havia fet de Palma per Riba-roja amb el rei Pere el Gran. Per això Jaume II encarregà a Ferrer Descortell, batlle general del regne de València, que s'informés si el peatge que Ramon de Riusec exigia es pagava

204 ACA, C, reg. 1849, f. 34 r.-v. (1391, febrer, 27).

205 J. E. MARTÍNEZ FERRANDO, Catálogo de la documentación relativa al antiguo reino de Valencia..., I, Jaime 1 , doc. 719 .

206 ACA, C, reg. 1845, f. 27 r. (1390, febrer, 28), i reg. 1897, ff. 189 v.-190 r. (1390, febrer, 17). Cf. el guiatge atorgat a Guillem Salat, Bernat Llorenç i Vicenç Salat a reg. 1843, f. 78 r.-v. (1389, febrer, 17). Els porters del rei reberen ordre d'ajudar-los i fins i tot d'acompanyar-los personalment si ho demanaven: ibidem, ff. 78 v. -79 r.

207 ACA, C, reg. 134, f. 243 v. (1305, març, 7). Es conserva una carta original, sense any, del 9 de març, dels homes de Terol adreçada al rei, queixant-se que nobles $\mathrm{i}$ altres persones els prenien la fusta que baixava pel Guadalaviar amb el pretext de peatges: ACA, C, cr. Jaume II, caixa 89, núm. 10.914.

208 ACA, C, reg. 244 , f. 97 r. (1317, novembre, 15). 
o no en temps del canvi ja que, en cas afirmatiu, la Corona havia de defensar, efectivament, els seus drets ${ }^{209}$.

Després foren els homes d'Artal de Luna a Benaguasil els qui crearen problemes. L'alcaid d'aquest noble exigia un impost desacostumat també i per tal de cobrar-lo retingué la fusta que baixava pel riu, cosa que motivà la reacció immediata de la ciutat de València, que envià el seu exèrcit contra Benaguasil per a tallar aquest abús. Jaume II hagué de sol.licitar la intervenció del procurador del regne de València, Gilabert de Centelles, i del batlle general, Ferrer Descortell ${ }^{210}$. L'any 1320 el problema encara continuava vigent i Jaume II encarregà al nou governador del regne, Pere de Queralt, que mirés de buscar una solució a l'impost demanat per Artal de Luna a Benaguasil ${ }^{211}$.

L'any 1388 eren els castellans els qui demanaven impostos no acostumats i trasbalsaven el transport de la fusta. Sembla que tradicionalment la fusta que baixava pel Guadalaviar o per terra i que pertanyia a ciutadans de València només pagava a Castella un dret de passatge o portatge que era el cinquantè del valor. Malgrat això, alguns veïns de València que, cap a l'any 1387, havien fet tallar fusta de pi a Albarrasí i l'havien baixada pel riu es trobaren que alguns oficials castellans del terme de Moya els exigiren, a més del cinquantè, un delme $i$ altres drets $i$ retingueren part de la fusta com a garantia del pagament. Per a recuperar la fusta embargada hagueren de donar fiança d'estar a dret. La ciutat de València, com que era una cosa d'interès comú, demanà al rei de Castella que desembargués la fusta i el monarca decidí que la qüestió fos resolta per dos àrbitres, un per Castella i un altre per la Corona catalano-aragonesa. Per Castella fou nomenat Ferran López Zapata, de Requena, mentre que el rei Pere nomenà Ramon Tolsà. La mort del rei Pere deixà en suspens els nomenaments i per això Joan I confirmà el de Ramon Tolsà, l'any 1388 , perquè la qüestió pogués resoldre' $\mathrm{s}^{212}$. La mort del rei de Castella, Joan $\mathrm{I}$, aturà una altra vegada la solució d'aquest litigi i per això, pel febrer de 1391, Joan I el Caçador demanà al seu nebot, el monarca castellà, que tornés a nomenar comissaris per a resoldre' $\mathrm{I}^{213}$.

Cap a l'any 1393 els castellans començaren, a més, a demanar l'impost anomenat quema per la fusta que passava per llur territori, baixant pel Guadalaviar. La quema era un impost que es collia en els estats de la Corona catalano-aragonesa i a Castella sobre el comerç mutu, des dels tractats de pau d'Enric II amb Pere el Cerimoniós, almenys, a fi d'indemnitzar els súbdits respectius que havien sofert danys en els períodes de pau o treva compresos entre les diferents etapes de la guerra castellano- catalana i després d'acabada ${ }^{214}$. Joan I protestà per aquest fet, perquè els capítols de la quema excloïen de l'impost les mercaderies de pas, que en aquest cas era forçat pel traçat del riu, i perquè en els seus regnes hom no el cobrava als

209 ACA, C, reg. 243, f. 270 r.-v. (1317, abril, 6).

210 ACA, C, reg. 244 , ff. 316 v., 317 r. -318 v i 319 v.

211 ACA, C, reg. 246, f. 28 r.-v. (1320, maig, 28).

212 ACA, C, reg. 1836, ff. 30 r.-31 r. (1388, setembre, 10).

213 ACA, C, reg. 1875 , f. 160 v. (1391, febrer, 22).

214 M.T. FERRER I MALLOL, La ruptura comercial amb Castella i les seves repercussions a Valiencia (1403-1409), «Primer Congreso de Historia del País Valencianow, II, Universidad de Valencia, 1981, pp. 672673. 
castellans de pas. Com que Castella al.legava que l'exempció es referia només a les mercaderies de pas per mar, Joan I manà al jurista valencià Joan Mercader, que era comissari de la quema, que quan es reunís amb el seu col.lega castellà a la frontera denunciés aquest fet i fes modificar el capítol primer de l'estatut de l'impost a fi que quedés clar que la franquícia de pas incloïa també els rius ${ }^{213}$. L'afer no degué quedar resolt definitivament, perquè l'any 1401 el conseller del rei, Domingo Mascó, es queixà perquè els col.lectors de la quema a Moya li exigiren aquest impost per la fusta que havia tallat a Albarrasí i havia fet baixar pel Guadalaviar; a més, es queixà perquè li havien pres una gran quantitat de fusta de la que havia comprat a Castella, per la qual havia pagat tots els impostos deguts ${ }^{216}$.

A vegades les dificultats en el transport provenien del fet que alguns usuaris no respectaven l'ordre de baixada de la fusta dels diferents propietaris i provocaven confusió en la mercaderia. L'infant Martí amonestà Pere de Montsó, fuster de València, i els "ganyers» o conductors de la seva fusta perquè l'havien barrejada amb la cabana de troncs que el tresorer del rei, Pere Desvalls, feia baixar també pel Guadalaviar des d'Albarrasí fins a València. Els havien advertit que no volguessin passar davant de la fusta del tresorer, que havia estat «engravada» o posada primer en el riu, però no n'havien fet cas i l'havien barrejada. L'infant els manà que en el terme de tres dies després de la presentació de la carta destriessin llur fusta de la del tresorer, altrament amenaçava de procedir contra seu. Aquest manament de l'infant fou fet el 20 de setembre de 1378; cinc dies després, però, el revocà perquè, després de l'altercat entre Jaume Coll, que menava la fusta del tresorer, i Pere Montsó, ambdues parts havien nomenat àrbitre el canceller de l'infant i s'havien obligat a satisfer-se mútuament els danys. L'infant comunicà, doncs, a Pere López, porter del rei, i a Mateu Alanyà i a Pasqual de Peralta, majorals de la cabana de fusta del tresorer del rei, que deixessin que totes dues cabanes baixessin juntes pel riu ${ }^{217}$.

En temps de guerra, el transport de fusta, com el d'altres mercaderies, podia sofrir algunes contrarietats. Poc després de començar la guerra amb Castella de 1296-1304, la fusta dels castellans que fou trobada a la riba del Guadalaviar, a València, fou confiscada, bé que una part fou reclamada per un veí de Xèrica, Pasqual Alfonso, que assegurà que l'havia comprada a castellans abans de la guerra ${ }^{218}$. Cal dir, però, que el transport de fusta pel Guadalaviar era tan vital que en moments de tensió entre la Corona catalano-aragonesa i Castella Pere el Cerimoniós li dispensà un tractament especial. L'any 1336,per exemple, Pere el Cerimoniós posà sota el seu guiatge tots els castellans i qualssevol altres que portessin fusta a València pel riu ${ }^{219}$. Una concessió semblant de l'any 1346 especificà que el guiatge seria vàlid encara que hi hagués guerra entre els regnes d'Aragó i Castella; en cas de revocació, valia encara sis mesos ${ }^{220}$. Suposem, però, que durant la guerra dels dos Peres, a mitjan segle XIV, aquest tràfic degué quedar suspès.

215 ACA, C, reg. 1855, ff. 57 v.-58 r. (1393, abril, 7).

216 ACA, C, reg. 2287, f. 63 r.-v. (1401, desembre, 12).

217 ACA, C, reg. 2067, f. 73 r.-v. (1378, setembre, 20) i f. 76 v. (1378, setembre, 25).

218 ACA, C, reg. 340 , ff. 25 r. i 111 r. (1296, maig, 7 i 28$)$.

219 ACA, C, reg. 860, f. 102 v. (1336, desembre, 21).

220 ACA, C, reg. 880, f. 180 r.-v. (1346, maig, 29). 
Durant la guerra de la Unió, una guerra interna, la fusta dels ciutadans de València que baixava pel Guadalaviar també fou confiscada i adjudicada al noble Pere de Xèrica que, com a senyor d'alguns llocs de la riba del riu, estava en bona situació per a emparar-se' $n^{221}$.

Les marques i represàlies també tingueren incidència en el transport de la fusta. Abans de l'any 1322, el batlle general del regne de València havia decretat una marca contra castellans per motius que desconeixem; l'execució d'aquesta marca degué afectar béns de gent de Moya perquè aquesta vila respongué confiscant fusta i d'altres béns que pertanyien a súbdits de Jaume II i, a més, com que temia una altra represàlia a València, no deixà passar fusta de Castella cap al País Valencià. Per tal d'evitar els perjudicis que això ocasionava, Jaume II hagué de concedir un guiatge als veïns de Moya i a qualsevol castellà que portés fusta al País Valenciàa ${ }^{222}$.

El riu Xúquer.- També al riu Xúquer hi havia activitat en el transport de fusta. El Xúquer neix a la província de Conca, als Monts Universals, i travessa zones boscoses, alguna de les quals porta el nom significatiu de Sierra de la Madera; aquestes comarques castellanes tingueren una explotació forestal des d'antic, una bona part de la qual anava cap al País Valencià.

La fusta que baixava pel riu pagava un impost al rei, anomenat cinquantè. L'any 1261 Jaume I havia concedit als veïns d'Utiel franquícia del dret de lleuda i peatge sobre la fusta que baixava pel Xúquer, mentre li lliuressin un fust o tronc de cada cinquanta ${ }^{223}$; suposem que aquest tribut es féu extensiu a tota la fusta castellana que baixava pel riu i que d'aquí vingué el nom de cinquantè. L'impost es cobrava al gual de Barragà, situat a la vall de Càrcer, com a dret del castell de Xàtiva; posteriorment aquest lloc fou conegut com la Barca d'Alcosser o la Barca del Rei i actualment en queda el record en un Camí de la Barca i una Casa de la Barca ${ }^{224}$.

L'any 1315 sorgí un litigi entre Jaume Andreu, que era llavors batlle de Xàtiva, i Gonzalvo Zapata, de Borja, per causa del pagament del cinquantè d'una cabana de fusta que feia baixar pel Xúquer des de Castella. Sembla que Gonzalvo Zapata s'emparava en els furs d'Aragó per a no pagar-lo i per això, perquè la qüestió afectava les seves regalies, Jaume II es reservà la causa per a la seva cort ${ }^{225}$.

L'any després es plantejà la qüestió des d'un altre punt de vista, però que segurament tenia una certa relació amb el cas anterior, encara que no tinguem la certesa que Gonzalvo Zapata fos un dels que defugien l'impost amb un engany; arribà a oïda del rei que hom defraudava el cinquantè d'una part de la fusta que venia de Castella i baixava pel Xúquer, perquè els qui la portaven la venien a gent de la Corona catalano-aragonesa abans d'arribar al gual de Barragà, on calia pagar-lo. Recordem que els valencians estaven exempts d'impostos de trànsit per la fusta des

221 ACA, C, reg. 888, f. 215 r. (1349, maig, 19) i reg. 889, f. 92 v. (1349, desembre, 11).

222 ACA, C, reg. 247, ff. 40 r.-v. (1322, març, 23).

223 J. E. MARTÍNEZ FERRANDO, Catálogo de la documentación relativa al antiguo reino de Valencia..., I, Jaime I, doc. 338.

224 A. VENTURA, Les demarcacions bistòriques de la Xàtiva foral, «Xàtiva. Fires d'Agost», 1986, pp.4748.

225 ACA, C, reg. 243 , f. 19 r. (1315, desembre, 10$).$ 
de l'any $1268^{226}$ Per a evitar el frau, el rei disposà que tota la fusta que baixés pel Xúquer fos treta de l'aigua («exaguare») al gual de Barragà i pagués l'impost abans d'ésser venuda; els que defraudessin l'impost haurien de pagar per cada infracció un multa de 100 sous reials i, si el justícia d'Alzira trobava fusta, aigües avall del riu, que no hagués pagat l'impost al batlle de Xàtiva, havia de prendre penyores pel valor de la multa indicada ${ }^{227}$.

L'ocupació de terrenys vora el riu al gual de Barragà per a posar-hi la fusta a eixugar provocà discussions amb els propietaris de les terres, particularment amb Francesc de Pròixida. Un interdicte judicial prohibí que ambdues parts usessin les terres en litigi, però la necessitat obligà els conductors de la fusta a dipositar-la igualment a la riba, per la qual cosa els oficials reials volien imposar la multa corresponent. El rei demanà que per interès públic $\mathrm{i}$ del fisc fos permès l'ús dels terrenys en litigi per a posar-hi la fusta, sempre que els usuaris es comprometessin a esmenar els perjudicis que hi causessin ${ }^{228}$.

L'impost del cinquantè fou usat força sovint, com qualsevol altra renda reial, per a premiar serveis de consellers o domèstics dels reis. L'any 1336 Pere el Cerimoniós renovà el manament al batlle de Xàtiva perquè lliurés 60 fusts o troncs provinents d'aquest impost a Ximèn de Tovia, conseller seu, a qui havien estat concedits per la reina Elionor, vídua d'Alfons el Benigne,concessió que ja havia estat ratificada pel Cerimoniós, però que el batlle no havia acomplit ${ }^{229}$. L'any $1351 \mathrm{el}$ mateix Pere el Cerimoniós donà 300 troncs d'aquest impost a Pere de Vilanova, alcaid de Xàtiva, per tal d'agrair-li els seus serveis durant la guerra de la Unió i compensar-lo per la pèrdua de la seva casa a Alcúdia, enderrocada pels revoltats ${ }^{230}$.

Bé que, com ja ho hem dit, hom cobrava l'impost al gual de Barragà, en alguna ocasió el rei canvià el lloc de pagament. Per exemple, l'any 1397 Martí l'Humà decidí que fos pagat a Cullera, a la desembocadura del riu, per tal de poder transportar amb menys cost els troncs de l'impost a Barcelona, on el monarca els necessitava per a la construcció d'un palau nou i per a la construcció de galeres. El canvi havia de durar només mentre el rei necessités aquesta fusta i no afectava, tampoc tota la fusta que baixava pel riu sinó només la més grossa; els cabirons i trossos de fusta havien de continuar pagant al lloc habitual ${ }^{231}$.

Alguns mesos abans del mateix any 1397 la reina Maria havia volgut saber què rendia aquest impost $i$ què havia rendit en els darrers vuit o deu anys. Demanà la informació a Antoni de Vilaragut, alcaid del castell de Xàtiva que, doncs, devia tenir alguna intervenció en la recaptació de l'impost, malgrat que devia ésser administrat pel batlle de Xàtiva, a qui s'adreçà el rei en la carta del mateix any que acabem de

226 J. E. MARTÍNEZ FERRANDO, Catálogo de la documentación relativa al antiguo reino de Valencia..., I. Jaime I, doc. 719 .

227 ACA, C, reg. 243, ff. 54 v. -55 r. (1316, febrer, 18).El terme kexaguadorn, és a dir eixaguador o eixugador, que era el lloc on es treia la fusta del riu perquè perdés aigua, s'ha conservat en un indret del terme: $\mathbf{A}$. VENTURA, Les demarcacions bistoriques de la Xàtiva foral, p. 48.

228 ACA, C, reg. 244, f. 240 v. (1318, març, 4).

229 ACA, C, reg. 864, f. 82 v. (1338, agost, 1$).$

230 ACA, C, reg. 894, f. 55 r. (1351, setembre, 6).

231 ACA, C, reg. 2230, f. 43 r. (1397, desembre, 22). 
comentar ${ }^{232}$. Desgraciadament no n'hem trobat la resposta, que hauria estat ben interessant per a conèixer el volum del comerç de fusta que seguia aquesta via.

Sembla que la fusta que baixava pel Xúquer pagava encara un altre impost a la Vall d'Aiora. L'any 1400, Bernat Manresana, que havia arrendat els impostos de la vall, protestà perquè uns mercaders d'Alzira havien defraudat l'impost que pagaven els estrangers que portaven troncs o béns d'altra mena pel Xúquer; havien assegurat que la fusta els pertanyia, cosa que segons l'arrendador era falsa, i que no havien de pagar perquè tenien franquícia ${ }^{233}$. El frau del canvi de propietat abans de pagar l'impost, per tal de defugir-lo, denunciat ja l'any 1316, tornava, doncs, a repetir-se, però ja no per gaire més temps.

En efecte, l'any 1403, o potser el 1402, Martí l'Humà concedí al seu nebot, el rei de Castella, que la fusta castellana que passava pels seus regnes tingués franquícia d'impostos. Hi havia una dificultat i era que el rei podia decidir suprimir els impostos reials, però no pas els impostos senyorials de passatge que cobraven diversos nobles amb dominis a tocar dels rius que eren vies forestals. Calgué que el rei emprengués una campanya persuasiva prop de cadascun d'aquests nobles perquè renunciessin a llurs impostos de passatge; sembla que tots ho feren, no sabem a canvi de quines promeses de part del monarca, llevat de Pero Sánchez de Calatayud, que en el moment de la negociació era absent en una missió oficial prop del papa a Avinyó. La seva muller accedí a deixar passar gratuiitament la fusta fins al retorn del seu marit, amb la condició que, si el dit Pero Sánchez de Calatayud no hi volia renunciar, caldria pagar-li els impostos no percebuts. El 10 de febrer de 1403, doncs, el rei Martí l'Humà informà el monarca castellà d'aquesta situación ${ }^{234}$.

El transport de tanta fusta pel Xúquer estimulà la implantació d'activitats complementàries a la comarca, com ara les serradores. L'any 1320, Jaume II concedí a Pere Calderó, «alumpno» o preceptor de l'infant Ramon Berenguer, que pogués construir prop de Xàtiva un molí per a serrar fusta i l'autoritzà a prendre del riu l'aigua necessària per a fer-lo funcionar sense perjudici de tercer. L'aigua la podria portar cap al seu molí a través de qualsevol propietat, indemnitzant-ne l'amo a parer del batlle de Xàtiva ${ }^{235}$.

\section{El transport terrestre}

Quan els boscos on hom talava la fusta no eren a tocar d'un curs d'aigua, calia transportar els troncs amb carros. Els documents no mencionen gaire sovint aquesta mena de transport, però fins i tot la fusta que després era posada en un riu primer solia fer algun camí amb carro. Un guiatge del 29 de maig de 1354 a favor de les persones que tallaven i transportaven fusta per al rei Pere el Cerimoniós, segurament per a la flota reial, mencionava els «aurigas curruum», els carreters; sembla que la fusta fou tallada a Castella, a la comarca de Moya ${ }^{236}$. Els animals usats per a la

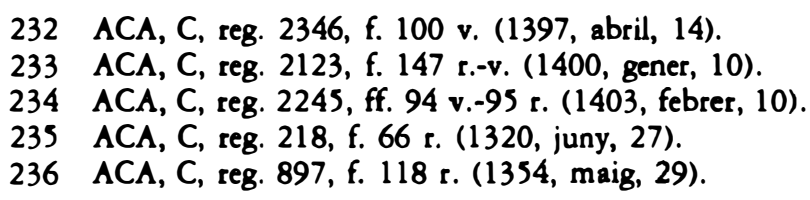


tracció, en aquests casos, podien ésser els bous. L'expedient usat l'any 1406, pels jurats d'Albarrasí per evitar que un veí tragués fusta del terme fou confiscar-li quatre parelles de bous. Aquest veí, Garcia Soriano, havia venut 100 càrregues de troncs a un mercader de València, Pere Gener, que li havia pagat una senyal de 100 florins d'or d'Aragó; amb aquests diners havia de fer la tallada d'arbres a un mas que tenia prop de la frontera amb Castella i transportar la fusta. Però els jurats d'Albarrasí volien que abans baixés pel riu la fusta que ells havien venut a un fuster de València, Joan Pérez, i per això prohibiren a Garcia Soriano que tragués la fusta $i$, per assegurar-se que no ho faria, li confiscaren els bous ${ }^{237}$. També uns barcelonins que feren tallar fusta a Aïnsa i a Organyà l'any 1440 hagueren de comprar, per al tram de transport terrestre, dues grans carretes $\mathrm{i}$ llogar parelles de bous ${ }^{238}$.

A Catalunya, un contracte per al transport de fusta per a la construcció d'una nau a Barcelona preveia que el carreter hi destinaria dos carros «bons e stables», tirats cadascun per tres rocins, i que no podria abandonar la feina fins que tota la llenya necessària no hagués estat transportada; les avaries dels carros, els accidents dels animals i el risc de la llenya transportada anaven a càrrec del carreter, mentre que, si calia adobar camins, la despesa havia d'anar a càrrec del constructor de la nau. El preu del transport variava una mica segons la distància; més enllà del coll de Montcada, on acabava la rodalia de Barcelona, hi havia un preu únic de 15 sous per cada carretada diària de vint quintars (uns $820 \mathrm{~kg}$ ), bé que tots els llocs esmentats en el contracte eren del Vallès i fins a un límit no més llunyà de Granollers i la Roca: Montmeló, Palou, Parets, Montornès, Sant Quirze, Sabadell, Sant Marçal, Sant Cugat, Sant Medir, Cerdanyola i Ripollet; de la Trinitat vers Barcelona el preu baixava a 8 sous per carretada; el constructor havia d'avançar al carreter cinquanta lliures; un cop sobrepassats paga i senyal, el carreter havia de cobrar per setmanes $^{239}$.

Certs contractes de venda d'arbres per a tallar, com ara un d'Albarrasí, que hem comentat abans, preveien que el venedor havia de proporcionar camí per a poder transportar la fusta des del lloc on era tallada fins al riu. Aquest camí havia de passar per on semblés millor als compradors, encara que calgués travessar penyes, deveses, terres llaurades o sembrades, bovalars, tancats etc., sempre que els compradors esmenessin els danys causats a les terres ${ }^{240}$.

En algun moment hi hagué discussió sobre si el trànsit de la fusta procedent dels boscos del rei havia de pagar drets de pontatge i de passatge. L'any 1365 un veí d'Aïnsa, Domingo de Roda, es queixà en nom propi $i$ del lloc, perquè els oficials reials els demanaven aquests impostos contravenint la franquícia que tenien per privilegi; aconseguí que la cort, interessada pel fet que proporcionava fusta prepara-

237 Martí l'Humà manà que Garcia Soriano pogués treure la seva fusta, que se li feia malbé, ja que només el rei podia dictar prohibicions d'aquesta mena: $\Lambda C \Lambda, C$, reg. 2149, f. 84 r.-v. (1406, octubre, 14).

238 C. CARRÈRE, Barcelona 1380-1462. Un centre econòmic en ipoca de crisi, I, p. 200.

239 J. M. MADURELL, Antiguas construcciones de naves, doc.7. Cf. també C. CARRÈRE, Barcelona 13801462. Un centre econòmic en èposa de crisi, I, pp. 198-201, que comenta aquest mateix contracte de transport $i$ alguns altres.

240 ACA, C, reg. 1849, f. 34 r.-v. (1391, febrer, 27). 
da per a la construcció de vaixells, expedís un manament perquè la franquícia de pas de la fusta d'Aïnsa fos respectada ${ }^{241}$.

\section{LES DEVESES, L'USDEFRUIT CONTROLAT DE LA NATURA}

L'increment de la població i la necessitat d'assegurar llenya, fusta, carbó, pasturatges i caça per als veïns de cada municipi aconsellà a moltes poblacions d'habilitar en alguna partida del terme un territori on tots els veïns poguessin gaudir d'aquells subministraments per a l'ús domèstic i on ningú més tingués accés sense autorització; d'aquí vingué el nom de devesa o vedat. També s'usà per a designar aquests espais el nom boalar o bovalar, bé que en principi no eren la mateixa cosa, ja que el boalar era un espai reservat per al bestiar de llaurar i per al dels carnissers $^{242}$.

En alguns casos s'aprofità, segurament, per a destinar-la a devesa alguna zona boscosa preexistent, però en uns altres sembla que es plantà de bell nou. Aquest devia ésser el cas del boalar o devesa de Castejón de Ateca (Castejón de las Armas), aldea de Calataiud, la creació del qual havia estat aprovada el 6 de març de 1267 pel justícia d'Aragó, en nom del rei. Els límits d'aquesta devesa eren, segons la toponímia esmentada pel document, del Castellejo cap a la porta de "Vayll de Roch", pujant per la vall fins a la "Penamlaya» $i$, d'aquí, al cim de la vall, des d'on continuava per la carena fins a un terrenys pertanyents a la confraria i d'aquí pel camí fins a les terres de García de Artasona i, baixant per la vall, fins al Forcall de la vall d'Iglesias i d'aquí, baixant pel camí, fins al Castellejo.

L'any 1326, quan la devesa, gràcies a la cura i a la vigilància dels veïns, havia germinat i crescut, cosa que indica, doncs, que havia estat plantada, els homes dels llocs veïns, contra la voluntat dels habitants de Castejón, entraven en el boalar, hi tallaven llenya i la'n treien furtivament, hi caçaven i hi feien pasturar llurs ramats, amb gran perjudici dels veïns de Castejón, que se'n queixaren al rei i obtingueren un manament segons el qual podrien prendre penyores als qui s'aprofitessin de llur devesa i podrien imposar-los les penes previstes pels furs i usos d'Aragón ${ }^{243}$.

Hi ha notícies de creació $\mathrm{i}$ aprovació de deveses a favor de diverses poblacions al llarg dels segles XIII, XIV i XV per part de diferents autoritats: el rei o bé els nobles, els ordes militars $i$ altres senyors en llurs dominis, ja que en principi els municipis, $i$ encara menys un particular, no podien per ells mateixos decidir una cosa que afectava l'ordenació del territori i que podia lesionar els drets d'un tercer.

Les poblacions no podien tampoc ampliar les deveses concedides o fer-ne de noves sense llicència de l'autoritat competent. L'any 1303, per exemple, Jaume II amonestà els veïns de la vila turolesa de Mosqueruela perquè, malgrat que ja tenien una devesa des d'antic, n'havien feta una altra al terme del lloc valencià de

241 ACA, C, reg. 723 , f. 23 v. (1365, agost, 6).

242 V. FAIRÉN GUILLÉN, Consideraciones juridicas sobre los boalares de Aragón, "Anuario de Derecho Aragonésn, I (1944), pp. 399-432.

243 ACA, C, reg. 228, f. 36 v. (1326, febrer, 27$)$. 
Vilafranca del Maestrat, cosa que havia suscitat les protestes d'aquesta vila i de Morella. Probablement la nova devesa era en un terreny disputat entre Mosqueruela i Vilafranca, però l'advertència del rei es referia a la il.legalitat de fer nova devesa sense llicència i sense ajustar-se a les proporcions del lloc; és a dir, una vila petita no podia tenir més extensió de devesa de la que realment necessitava ${ }^{24}$. De la mateixa manera, Jaume II ordenà al batlle d'Albarrasí, l'any 1307, que suprimís les deveses concedides pel Consell de la vila a alguns veïns, en perjudici dels seus drets i dels de la majoria d'habitants del $\operatorname{lloc}^{245}$.

Durant el segle XIV es multiplicaren les concessions de deveses ja que, quan un municipi en tenia, els pobles veïns s'havien d'afanyar a aconseguir-ne una per tal de no quedar en desavantatge, altrament llur terme podia concentrar les apetències dels pastors o dels llenyataires forasters i quedar sotmès a una sobrexplotació perjudicial per als veïns. Una aldea de Terol, Santa Eulàlia, que en demanà, l'any 1334, utilitzà, entre altres arguments, el fet que els llocs veïns en tenien ${ }^{246}$.

Hi ha milers de notícies documentals sobre les deveses de Catalunya, d'Aragó $\mathrm{i}$ del País Valencià, tant sobre la creació com sobre les dificultats de funcionament. Els documents de creació són extraordinàriament interessants perquè solen donar els límits de la devesa, cosa que permetria fer-ne la cartografia, cas per cas, i comprovar el manteniment d'aquestes antigues reserves naturals, que han servit per a preservar durant segles els nostres boscos i espais no conreats, mitjançant un usdefruit controlat.

Les notícies que presentem ara no són exhaustives, ni de bon tros: cal buidar sistemàticament les col-leccions diplomàtiques publicades, les històries locals, els estudis sobre monestirs, etc. i continuar el buidat dels registres de cancelleria. Així i tot, les notícies que hem reunit són ja molt nombroses $\mathrm{i}$ creiem que val la pena de fer-ne un avançament. Les agrupem per territoris; no hi és present Mallorca perquè no hem trobat documentació referent a les Illes.

Catalunya.- Pel que fa al Principat, una de les primeres deveses de què tenim notícia per ara és la del monestir de Vinganya, de l'orde de la Trinitat, atorgada pel rei Pere el Catòlic l'any 1205, concessió que s'ha conservat, inclosa en la confirmació feta pel rei Jaume II l'any 1326. La devesa, com el mateix monestir, era propera a Lleida i limitava amb el riu Segre i els termes de Serós i de Masalcoreig. Pere el Catòlic disposà que ningú no hi pogués caçar, tallar-hi llenya o arbres ni fer-hi cap mal sota pena de 60 sous $^{247}$. Sabem també que el bisbe de Tortosa tenia en aquesta època una devesa de conills a Lledó. Quan concedí carta de població per a aquest lloc, l'any 1210 , la retingué per a ús propi ${ }^{248}$.

De l'any 1258 data la carta de població concedida per Guerau d'Amic, mestre de l'orde de l'Hospital, als moros de l'Aldea, en la qual els fou concedida devesa per a

244 ACA, C, reg. 128, f. 228 r. (1303, juliol, 29).

245 ACA, C, reg. 140, f. 77 v. (1307, novembre, 20)

246 ACA, C, reg. 858, f. 76 r.-v. (1336, maig, 13).

247 ACA, C, reg. 228, f. 30 r.-v. (1326, febrer, 21).

248 J. M. FONT RIUS, Cartas de población y franquicia, I, doc. 232. 
tenir llurs bestiars a les terres compreses des de la via que anava a Tarragona fins al mar ${ }^{249}$.

La devesa de Freginals, fou concedida pel comanador d'Ulldecona, de l'orde de l'Hospital, l'any 1274 . El document de concessió $n$ 'assenyalà els límits $i$ autoritzà els veïns de Freginals a ordenar-ne l'aprofitament segons el costum d'Ulldecona ${ }^{230}$.

En algun cas, algun dels nuclis de població de la Catalunya nova s'assentà en els terrenys d'una devesa. Per exemple, Berenguer de Cardona, mestre del Temple, cedí a Guillem Vaquer "totam dominicatam nostram seu devesiam" del castell de Miravet, anomenada la devesa de Massaluca, perquè la poblés amb unes vint families; la devesa es convertí així en la Pobla de Massaluca ${ }^{231}$.

De l'any 1302 tenim notícia de la concessió per part de Guillem d'Entença d'una devesa als habitants d'Almatret, en la qual no podrien entrar estranys ${ }^{232}$.

En alguna ocasió la concessió d'una devesa fou utilitzada per la Corona com una manera de premiar els serveis prestats per una persona concreta; és el cas de Romeu Llull a qui, l'any 1372, Pere el Cerimoniós concedí que pogués convertir en devesa les terres que posseïa a Sant Andreu de Palomar, Sant Martí de Provençals i Sants, tant si eren feudals com al.lodials. Ni els carnissers ni ningú no hi podria portar a pasturar bestiar gros o menut, ni caçar-hi conills, llebres, perdius, coloms, paons etc., amb ballesta, parany o art, ni pescar-hi peixos en els recs i en els molins fariners de Sant Andreu o en els molins drapers de Sant Martí de Provençals. A més el rei li concedí, tal com ja ho hem comentat, que els almiralls i els vice-almiralls no podrien fer-hi tallar arbres per a la construcció de naus o de galeres armades ${ }^{233}$.

Alguns consells municipals tingueren potestat per a assignar bovalars en els llocs del seu terme o de la seva àrea d'influència. Per exemple, l'any 1386 el Consell de Lleida assignà bovalar als veïns de Vilanova d'Alpicat que ho havien demanat. Bernat Gralla fou comissionat perquè anés al lloc i revisés els límits del bovalar sol.licitat, que són indicats i que confrontaven amb el terme del lloc de Rosselló $\mathrm{i}$ un altre vedat que hi havia a Torreferrera. El càstig per als infractors era la degolla d'una ovella o animal petit de dia i dos de nit. Aquesta concessió fou confirmada l'any 1418 pel rei Alfons el Magnànim 24 .

Durant el regnat d'Alfons el Magnànim, el monarca atorgà devesa a diferents persones de Catalunya i del Rosselló. A Catalunya en concedí una a Lleonard Antic en el lloc del Prat, anomenat també devesa d'en Bellvís, que posseïa en franc alou. El concessionari s'havia queixat perquè, malgrat que tenia aquesta propietat voltada d'una sèquia o vall, molta gent hi introduia bous $i$ animals d'altra mena $i$ hi caçaven i hi tallaven llenya contra la seva voluntat. La carta reial precisà els límits de la

249 J. M. FONT RIUS, Cartas de población y franquicia, I, doc. 303.

250 J. M. FONT RIUS, Cartas de población y franquicia de Cataluna I, doc. 323.

251 P. ORTEGA, La carta de población de la Pobla de Massaluca (1295), *Acta Historica et Archaeologica Medisevaliaw, 7-8 (1986-1987), pp. 193-204.

252 J. M. FONT I RUUS, Cartas de población y franquicia de Catalunia, I, doc. 366.

253 ACA, C, reg. 923, ff. 43 v.-44 v. (1372, setembre, 14). Cf també J. FERNÁNDEZ I TRABAL, Aprofitaments commuals, prats i pastures al delta del Llobregat (segles XIV-XV). Conflictes por a la utilització de l'espai a la Baixa Edat Mitjana, «Acta Historica et Archaeologica Mediaevalia», 10 (1989), p. 213.

254 ACA, C, reg. 2588, f. 142 r.-144 r. (1418, novembre, 24). 
devesa i establí que els infractors incorrerien en multa de 30 sous cada vegada $\mathrm{i}$ perdrien la caça i els aparells; un terç de la multa seria per a Lleonard, un terç per al rei $i$ un terç per a l'acusador o el guardià de la devesa $a^{23 s}$. L'any 1457 aquesta devesa tenia, aproximadament, 150 mujades d'extensió, de les quals 77 eren de conreu, segons un inventari estudiat per J. Codina ${ }^{236}$.

Al Rosselló concedí devesa, per exemple, a Bernat Desvoló, donzell, en el seu mas "Desvoló», al terme del castell «Depassa»; el mas, que era en part conreat, havia d'ésser vedat d'herbes, de caça i de llenya ${ }^{23}$; a Francesc Batlle, al bosc que tenia a Clairà, com a vedat de pastura, de caça i de llenyaa ; a Berenguer Descallar, donzell, a unes terres al.lodials, de 80 aimines d'extensió, que tenia Sant Hipòlit i que eren plantades amb diversos arbres $i$ ja estaven tancades ${ }^{299}$; $i$ a Joan Bages, carnisser de Perpinyà, a Orla, en unes terres que en part eren conreades $i$ en part no $i$ per on passava la Tet, dins del terme de Sant Esteve, que pertanyia als hospitalers. La pena prevista per als infractors era de 60 sous i 1 diner, la meitat de la qual seria per al comanador d'Orla ${ }^{260}$.

La Corona tenia també una devesa a Perpinyà, que no sabem si coincidia amb el bosc annex al castell i del qual ja hem parlat. L'any 1376 sembla que Pere el Cerimoniós s'havia indignat tant per la caça furtiva que hom practicava a la seva devesa que ordenà al governador de Rosselló i Cerdanya que fes cridar a Perpinyà que, si algú gosava caçar-hi hauria de pagar una multa de mil morabatins d'or $i$, si era reincident, seria executat; si l'infractor era home de paratge, seria decapitat i, si era peó, seria penjat. Pocs mesos després, però, s'adonà que la pena era exagerada i deixà el càstig a les infraccions en 60 sous per cada vegada, que era la quantitat acostumada ${ }^{261}$.

País Valencià.- Entre les concessions de deveses més antigues del País Valencià figura la que Jaume I concedí, l'any 1257, a l'orde de Santiago quan li donà un lloc proper al castell de Garmoixent, d'una milla d'extensió, on podria tenir vedat de conills $^{262}$. Un altre vedat de conills, i de caça en general, fou concedit pel mateix rei a Robau de Voltorasc, l'any 1269, als termes de Morvedre i Almenara, tocant al mar i fins al límit amb Canet ${ }^{203}$.

Malgrat que la devesa de Morella és esmentada ja l'any 1284, quan el rei Pere III prohibí al bisbe de Tortosa de fer-hi innovacions ${ }^{264}$, Alfons el Liberal en concedí

255 ACA, C, reg. 2591 , ff. 181 r.-182 r. (1429, octubre, 12). Cf. també J. FERNANDEZ I TRABAL, Aprofitaments comunals, prats $i$ pastures al delia del Llobregat (segles XIV-XV), pp. 214-215.

256 J. CODINA, Els pagesos de Provenfana (984-1807). Societat i economia a l'Hospitalet pre-industrial, Ajuntament d'Hospitalet- Publicacions de l'Abadia de Montserrat, 1987, I, p. 347.

257 ACA, C, reg. 2593 , ff. 101 v. -102 r. (1424, abril, sense dia).

258 ACA, C, reg. 2593 , f. 110 r. (1424, setembre, 16).

259 ACA, C, reg. 2592, f. 130 r.-v.(1425, marş, 14).

260 ACA, C, reg. 3153 , ff. 16 r.-17 r. (1441, gener, 12).

261 ACA, C, reg. 930, f. 14 r.-v. (1377, gener, 9).

262 R. SAINZ DE LA MAZA, La orden de Santiago en la Coroma de Aragón. La Encomienda de Montalbán (1210-1327), Saragossa, Institución Fernando el Católico, 1980, doc. 43.

263 ACA, C, reg. 16, f. 199 v. (1269, agost, 27); cf. J. E. MARTínez FerRANDO, Catál ogo de la documentación relativa al reino de Valencia..., I, Jaime 1 , doc. 940.

264 J. E. MARTÍNEZ FERRANDO, Catálogo de la documentación relativa al reino de. Valencia, II. Pedro el Grande, doc. 1929. 
una l'any 1289 a la mateixa vila. Era situada a les valls de Vallivana i de Salvasoria i havia de servir només per al bestiar dels veïns de Morella ${ }^{263}$. També Alpont sembla que tenia una devesa, pertanyent al rei; l'any 1287 Alfons el Liberal encomanà a Bernat Escrivà que s'informés si els veïns del lloc havien usurpat aquesta $i$ altres propietats reials ${ }^{266}$.

L'any 1308 fra Arnau d'Amer, mestre de l'orde de la Mercè, es queixà perquè Ximèn Pérez d'Andilla havia fet un bovalar al terme d'Assuévar, al costat del terme d'Algar, que pertanyia als mercedaris $\mathrm{i}$ impedia llavors als veïns d'aquest darrer lloc d'entrar-hi llur bestiar a pasturar, com havien acostumat a fer- ho $\mathrm{i}$ com hi tenien dret segons el pasturatge d'era en era ${ }^{267}$, costum aragonès que ja hem comentat abans.

L'orde de l'Hospital tenia un bovalar a Sueca per als homes del lloc. L'any 1300 el procurador de l'Hospital es queixà perquè els carnissers de València hi portaven el bestiar a pasturar i perjudicaven els veïns de Sueca ${ }^{268}$.

L'any 1335 la Pobla de la Vall de Sant Miquel, aldea d'Ademús, demanà al rei Alfons el Benigne que li concedís una devesa o boalar perquè el terme on els habitants de la Pobla solien pasturar el bestiar des d'antic, que confinava amb els termes castellans de Moya, Cañete i Santa Cruz, era usat i devastat pels veïns d'aquests llocs. El monarca hi envià el seu conseller i vice-canceller, Rodrigo Díez, el qual es reuní amb els prohoms de la Pobla i fixà els límits de la devesa, especificats a la concessió, que coincidien, en part, amb els de la frontera castellana. La concessió fou confirmada pel rei Pere el Cerimoniós l'any $1336^{269}$

L'infant Martí es reservà també, l'any 1381, una devesa a Xèrica per tal de tenir carbó a l'hivern per a la seva casa i els seus castells, pastures $i$ herbes per a les seves ovelles $\mathrm{i}$ fusta per a les reparacions que calia fer cada any a les seves cases $\mathrm{i}$ castells. Destinà a aquesta finalitat una part del terme, que precisament era motiu de plet a la cúria del governador de València entre ell, la vila i la tinença de Xèrica, d'una banda, i l'arquebisbe de Tarragona, com a senyor del castell de Montan, de l'altra. Quedava vedat, doncs, entrar a la devesa a tallar-hi arbres per a fer llenya o carbó, entrar-hi ramats, caçar-hi conills, llebres, perdius etc., sota pena de 100 sous. Els infractors perdrien els animals amb els quals traguessin productes prohibits de la devesa ${ }^{270}$.

A la ciutat de València hi havia, a més, una devesa del rei, situada entre el mar i l'albufera; segons la documentació medieval anava de la Gola de l'Alqueria al Trencador de la Conca. L'any 1318 Jaume II manà al batlle general del regne de València, Ferrer Descortell, que fes fer una crida a València prohibint que cap cavaller, ciutada o qualsevol altra persona gosés tallar llenya, caçar o fer-hi pasturar bestiar sota pena de 60 sous i que ningú no gosés conrear-hi terres sota pena de 100 monedes d'or, ja que havia sabut que s'hi tallava llenya, s'hi caçava, s'hi feia pasturar el bestiar i s'hi conreaven terres ${ }^{271}$.

265 R. GALLOFRÉ, Documentos del reinado de Alfonso III, doc. 1302.

266 R. GALLOFRÉ, Documentos del minado de Alfonso III, doc. 914.

267 ACA, C, reg. 141, f. 140 v. (1308, gener, 4).

268 ACA, C, reg. 114, f. 76 r. (1300, novembre, 10$)$.

269 ACA, C, reg. 860, ff. 57 v. -58 r. (1336, octubre, 15).

270 ACA, C, reg. 2070, f. 56 r.-v. (1381, març, 20).

271 ACA, C, reg. 244 , f. 277 r. (1318, maig, 1). 
Aragó.- A la Franja de Ponent, és a dir, a les terres de parla catalana frontereres amb el Principat, i concretament a la comarca del Matarranya, correspon la notícia més antiga, entre les que hem pogut reunir, de creació d'una devesa. Es inclosa a la carta de població concedida per Rodrigo de Bolea i Sancho de Sariñena i llurs mullers respectives als pobladors de Calaceit, el mes d'abril de 1207 . Els atorgaren usdefruit de pastures i d'aigua a tot el terme i devesa per a poder caçar-hi conills a una partida de terra limitada per un camí que anava al coll de la Mola, el riu Algars, diversos masos,el vessant de Vall-Rovira i el terme d'Arenys. Més endavant, quan Calaceit ja pertanyia a l'orde de Calatrava, fou concedida als pobladors una nova carta de població, l'any 1278 , en la qual l'orde els confirmava l'usdefruit de les pastures i de l'aigua per a abeurar el bestiar i per a pescar-hi, el dret de tallar fusta seca i verda per a llurs cases i de caçar tot l'any a tot arreu menys a la devesa de l'orde. A més l'orde es comprometé a no fer cap altra devesa al terme ni a impedir el dret de pesca al riu Algars, els donà un tros de la devesa pròpia i els concedí un bovalar, que suposem que coincidia, més o menys, amb la devesa atorgada l'any 1207 per Rodrigo de Bolea i Sancho de Sariñena. Els límits donats ara eren els horts de Maça Olzines, la Pedrafita, la Pedra Cavallera, la Covatiella de dona Portolesa, la font de les Ferreres, diversos horts, la Vall-Rovira i el riu Algars. Malgrat que l'orde s'havia reservat el dret de cobrar herbatge als forasters que portessin ramats a pasturar a Calaceit, el bovalar quedava d'ús exclusiu dels veïns del poble ${ }^{272}$.

Més al nord, a Sariñena, també prop de la frontera catalana, els veïns es queixaren perquè el sobrejunter d'Osca havia ocupat un bovalar que ells usaven per a fer pasturar el bestiar i que era situat al Montalbo i al mont Suelto; el rei Jaume II intervingué repetidament, l'any 1302, perquè els fos retornat ${ }^{273}$.

Encara una mica més al nord i més a l'interior d'Aragó, l'orde del Temple tenia una devesa a Bayben, en la qual els frares tenien dret de degolla del bestiar que hi entrava; cap a l'any 1300 l'orde es queixà que els homes de Tardienta hi portaven el bestiar a pasturar i obtingué un manament reial adreçat al sobrejunter d'Osca perquè ho impedís ${ }^{274}$

Força més lluny, a Rueda de Jalón, a la vall de l'Ebre, Jaume II concedí una devesa, l'any 1298, a Pedro Martínez de Luna. Era situada en un lloc anomenat Aguaviva; ningú fora del concessionari, o sense el seu permís, no hi podria fer llenya ni carbó ni hi podria caçar ni portar-hi a pasturar bestiar gros o petit; no era permès ni tan sols tallar-hi rams de llentiscle o collir-ne les fulles; ignorem quin ús hom donava a aquesta planta, que pogués motivar la reserva per al senyor ${ }^{275}$.

La documentació sobre creació i problemes entorn de les deveses és extraordinàriament abundosa en determinades àrees: la de Calataiud, la de Daroca, la de Terol i la d'Albarrasí.

Si examinem l'àrea de Calataiud, en primer lloc, trobem que els veïns de

272 J. MONCLUS, Una vila medieval entre fronteres, Calaceit al segle XIII, Barcelona, Xarxa Cultural,1987, pp. $91-97$ i $136-146$.

273 ACA, C, reg. 126, f. 197 r.- v. (1302, desembre, 28).

274 ACA, C, reg. 116, f. 175 r. $(1300$, setembre, 25$)$

275 ACA, C, reg. 110 , ff. 30 v. -31 r. (1298, març, 21$)$. 
Muñébrega es queixaren, l'any 1306, perquè els de Calataiud, contra llur voluntat, tallaven llenya $\mathrm{i}$ arbres a un boalar o devesa que tenien; els guardes de la devesa els havien pres penyores pel valor de la multa en la qual havien incorregut, però el justícia de Calataiud, que fou censurat pel rei per aquesta causa, no solament no ajudà els homes de Muñébrega, sinó que els molestà; el rei Jaume II, doncs, censurà el justícia $i$ li manà que fes pagar als homes de Calataiud les multes en què havien caigut $^{276}$.

El justícia de Calataiud tampoc no ajudà gens els veïns de Cubello, una aldea de Calataiud que prengué penyores a gent de Daroca perquè havien fet llenya en una muntanya que tenien com a devesa $\mathrm{i}$ vigilada per uns guardes. El justícia manà tornar les penyores preses, però els veïns de Cubello recorregueren al rei, present llavors a Calataiud, $i$ asseguraren que estaven disposats a acceptar la via de la justícia en el plet amb els de Daroca, però que no estaven obligats a tornar les penyores, proposta que el rei acceptà 27 .

L'ampliació de la devesa o boalar d'Añinón, l'any 1353, també portà polèmica. Una sentència judicial aprovà aquesta ampliació, demanada per Añinón perquè el boalar anterior havia quedat petit per al bestiar que tenien, que en resultava perjudicat, especialment en temps de neu. El jutge designat pel rei, Fernán Pérez de la Figuera, anà personalment al lloc, caminà pel terme i seguí els límits de la devesa antiga i de la nova que era proposada i l'aprovà; establí que els que hi fossin trobats tallant llenya o pasturant els ramats haurien de pagar una multa de 50 sous. La sentència fou comunicada als llocs veïns de Viver de la Sierra, Villarroya de la Sierra, Cervera i Torralba ${ }^{278}$. Els homes de Joan Martínez de Luna no respectaren el boalar $\mathrm{i}$ foren penyorats com a garantia del pagament de la multa en la qual havien incorregut, però no s'hi conformaren $i$ aquell noble i els seus homes, a cavall i a peu, atacaren a mà armada els d'Añinón i els prengueren quaranta caps de bestiar per a igualar les penyores que ells mateixos havien sofert. Atesa la gravetat de l'enfrontament, Pere el Cerimoniós confià la resolució de l'afer al justícia d'Aragón ${ }^{279}$.

També tingueren problemes per causa de llurs respectives deveses diverses aldees de Daroca. Els veïns de Tornos, per exemple, enviaren missatgers al rei el mes d'agost de 1303, quan era a Calataiud, per tal de queixar-se que alguns cavallers i gent de la rodalia entraven en un bosc o vedat que tenien i, sense llur autorització, hi tallaven llenya. Jaume II els manà que fessin guardar el bosc i que, si hi trobaven algú sense llicència, li prenguessin alguna penyora per a pagar la multa ${ }^{280}$.

Una altra aldea molt pròxima, la de Castejón, que tenia devesa des del 1244 per concessió de Jaume I, es queixà, l'any 1308, perquè els veïns de Báguena, Burbáguena, San Martín del Río, Cebollada, Villanueva (Villanueva de Jiloca), Valdehorna i Val de San Martín tallaven llenya a la seva devesa o boalar i hi ficaven llur bestiar; en consequèècia, Jaume II manà a l'alcaid i consell de Daroca i als homes d'aquestes aldees que no entressin a l'esmentada devesa perquè autoritzaria els guardians a

276 ACA, C, reg. 137, ff. 119 v.-120 r. (1306, febrer, 16).

277 ACA, C, reg. 141, f. 101 v. (1308, gener, 26).

278 ACA, C, reg. 896, ff. 92 v. -93 v. (1353, agost, 31).

$279 \Lambda C A, C$, reg. 679 , ff. 67 v. -68 r. (1354, gener, 27).

280 ACA, C, reg. 129, f. 11 r. (1303, agost, 9). 
prendre'ls penyores si hi anaven a tallar llenya o a fer-hi pasturar el bestiar ${ }^{281}$. El problema continuava encara un segle més tard. Els homes de Castejón recorregueren novament al rei, ara Alfons el Magnànim, per a queixar-se que no tenien altra riquesa que les muntanyes de "Casteñón" (o Castejón) i del Picozo i que, com que eren pocs, no podien defensar-se de la invasió de llur terme per gent d'altres llocs. Aquesta vegada el monarca autoritzà, finalment, l'aldea a exigir multes de 60 sous de nit i 30 de dia als infractors del vedat de pastura, llenya i caça ${ }^{282}$.

Pel que fa a Corbatón, presentà una queixa al rei Jaume II contra els veïns de Visiedo, Lidón, Argente i Rillo, que eren aldees de Terol, i contra Pancrudo i Alpeñés, que eren aldees de Daroca, perquè envaien la seva devesa ${ }^{283}$. Portalrubio, que devia tenir problemes semblants a la devesa que li havia estat concedida cap a l'any 1317, demanà l'any 1337 un augment de la multa prevista per als infractors del vedat, de 5 sous jaquesos a 60 , ja que considerava que 5 sous no eren dissuasoris. Per tal d'obtenir el consentiment reial oferí que un terç de la multa fos per al fisc i la resta per a la població, i aconseguí l'aprovació del monarca ${ }^{284}$. Villafranca aconseguí convertir en vedat per als ramats forasters el bosc del Carrascal $i$ una telleda veïna $i$ que els infractors haguessin de pagar una multa de 10 sous jaquesos de dia i 20 de nit per cada ramat de deu caps de bestiar menut, mentre que els ramats més petits havien de pagar 2 diners de dia i 4 de nit per cap. El bestiar gros havia de pagar de multa 12 diners de dia i 2 sous de nit. Piedraselz aconseguí que el rei assenyalés el mateix règim de multes per a la devesa o boalar que tenia des d'antic, entre els límits indicats al document ${ }^{285}$. També ho aconseguí Villarreal per a la devesa que tenia des del 1304, on els habitants dels pobles veins, contra la seva voluntat, tallaven llenya verda i seca, hi caçaven llebres, conills, perdius i cérvols i hi portaven el bestiar a pasturar $^{286}$.

Entre 1399 i 1400 dues aldees de Daroca, Odón i Bello, s'enfrontaren per una devesa que el rei Martí l'Humà havia concedit a Odón en un lloc on sempre els veïns d'aquest lloc havien fet pasturar llurs ramats. Però els de Bello recusaren la concessió perquè asseguraven que havia estat obtinguda amb falsedat i perquè ells no havien estat consultats. Suposem que en el fons hi devia haver un problema de límits dels termes d'ambdues poblacions ${ }^{287}$.

A la comarca de Terol les deveses també foren molt nombroses. Alfons el Benigne en concedí una l'any 1334 al consell de Santa Eulàlia, aldea de Terol. El Consell de l'aldea havia argumentat que tots els llocs veïns tenien devesa menys ells $\mathrm{i}$ que la necessitaven per a guardar-hi el bestiar a l'hivern, ja que el terme era àrid i hi mancaven pasturatges, raó per la qual el bestiar emmalaltia i moria. El rei els concedí llavors una devesa de conills, que havia estat atorgada a Alvaro Pérez, senyor

281 ACA, C, reg. 142, f. 253 r.-v. (1308, octubre, 25).

282 ACA, C, reg. 2593, f. 177 r. (1426, mars, 15). Malgrat que el document esmenta l'aldea amb el nom de Castenyón, suposem que es tracta de Castejón.

283 ACA, C, reg. 428, f. 26 r.-v. (1327, desembre, 18).

284 ACA, C, reg. 862, f. 2 v. (1337, setembre, 23$).$

285 ACA, C, reg. 875, ff. 203 v. i 204 r. (1343, desembre, 23) 286 ACA, C, reg. 875, f. 207 r. (1344, gener, 7)..

287 ACA, C, reg. 2123 , f. 189 r.-v. (1400, marc, 6). 
d'Albarrasí, l'any 1286, que limitava amb la carretera que anava a Daroca, la de Santa Maria, diversos accidents orogràfics, la cañada Fermosa i la partida de Las Madrigueras; ningú més que els veïns de Santa Eulàlia no podria caçar-hi conills, tallar-hi llenya o pasturar-hi el bestiar, segons la concessió d'Alfons el Benigne, que fou confirmada per Pere el Cerimoniós l'any $1336^{288}$.

Els veïns de Fuenferrada, aldea de Terol, es queixaren l'any 1344 perquè els de Portalrubio, la Zarzuela, la Loma i Torrecilla i alguns altres llocs veïns, contra llur voluntat, portaven bestiar a pasturar a llur devesa i boalar $i$ hi tallaven arbres $i$ llenya; per tal d'evitar que la destruïssin, demanaren de poder imposar multes de 10 sous de dia i 20 de nit cada vegada que hi fiquessin bestiar o hi tallessin fusta ollenya ${ }^{299}$.

Una altra aldea de Terol, Torrijas, tingué problemes de pastures quan la vila d'Alpont, que pertanyia al regne de València, però hi limitava, féu un boalar, l'any $1308, \mathrm{i}$ impedí que el bestiar de Torrijas hi entrés tal com ho acostumava de fer ${ }^{200}$.

El guardià de les cabanes d'Aragó també presentà una queixa contra Bernat Vives i la vídua de Sancho Muñoz, veïns de Terol, que havien fet boalar en una heretat que tenien en el terme d'aquesta ciutat $\mathrm{i}$ impedien l'empriu d'herbes $\mathrm{i}$ d'aigües al bestiar d'aquelles cabanyes, cosa que segons el guardià era contra fur. Jaume II encomanà al jutge de Terol que no permetés una actuació semblant. ${ }^{291}$ Ignorem, però, si la devesa era legal o no.

En efecte, hi havia particulars que demanaven la creació d'una devesa o boalar simplement perquè l'heretat que posseïen quedava lluny de la devesa de la població i els resultava carregós portar-hi cada dia el bestiar de llaurar. Aquest fou l'argument usat per Benita, vídua de Juan Lamata, que tenia una propietat al "Puerto de Casamden» al terme de Santa Maria de Valverde, aldea de Terol. L'hi concediren, l'any 1328, els alcaldes de Terol, com a vedat d'herbes, conills i perdius, segons el fur de Terol i fou confirmada, a instàncies del seu fill i hereu Domingo Lamata, per Pere el Cerimoniós l'any $1344^{292}$. Un argument semblant fou usat per Sancho Martínez Ladrón perquè el rei Pere el Cerimoniós li concedís de poder fer vedat en un prat que tenia a la seva propietat de "Celadiella», a Almansa, que era una de les aldees de Terol. Havia de quedar tancat entre una muntanya i una paret que pensava fer-hi; les heretats així tancades («cerade») quedaven vedades per al pasturatge de bestiar foraster ${ }^{293}$.

També Guillermo del Monje, veí de Terol, havia obtingut del jutge d'aquesta ciutat la concessió de boalar o devesa en una heretat que tenia a l'aldea de Valverde, anomenada «Las Pobediellas»; la concessió fou confirmada pel rei Alfons el Benigne i pel rei Pere el Cerimoniós, però posteriorment el jutge i altres veïns de Terol, amb el pretext d'una carta reial del 20 de setembre de 1352, que desconeixem, privaren

288 ACA, C, reg. 858, f. 76 r.-v. (1336, maig, 13).

289 ACA, C, reg. 875, ff. 209 v.-210 r. (1344, gener, 8).

290 El rei encomanà l'estudi de la queixa de Torrijas a Pedroto de Moya, veí de Terol: ACA, C, reg. 141, f. 155 r.-v. (1308, gener, 12).

291 ACA, C, reg. 142, f. 154 r. (1308, agost, 8).

292 ACA, C, reg. 875, f. 224 r.-v. (1344, gener, 17).

293 ACA, C, reg. 890, f. 196 r. (1350, maig, 5). 
Bartomeu Domínguez, successor de Guillermo del Monje, de l'usdefruit de la devesa, motiu pel qual recorregué al rei; el monarca ordenà que no fos privat de la devesa sense coneixement de causa ${ }^{294}$.

L'any 1374 Pere el Cerimoniós aprovà la concessió d'una devesa o boalar a Mateo Sánchez de Cutanda, feta per la ciutat de Terol l'any 1373. Mateo Sánchez de Cutanda havia comprat terres als llocs anomenats «Piqueras» $\mathrm{i}$ "Curriac» al terme de Camarena, aldea de Terol, i necessitava un boalar per al bestiar de llaurar. La concessió és interessant perquè permet de veure tots els passos seguits. Miguel Pérez de Marciella, en nom de la ciutat de Terol, reuní els jurats i homes de Camarena per sentir llur parer sobre el boalar demanat. A continuació els jurats de l'aldea i cinc prohoms anaren a visitar els límits del boalar, que són indicats i que foren aprovats, sempre que l'interessat deixés pas lliure pels llocs on transitava bestiar i que, si prenia penyores, no les tragués del terme de Camarena i de la jurisdicció de Terol $^{295}$.

El Consell de Terol també concedí una devesa a Marco Iñíguez de Tormón a una heretat que tenia a l'aldea de Cuevas Labradas, on li calia vedat d'herba per al seu bestiar; els infractors del vedat haurien de pagar 12 diners per cavall que hi entressin, 6 diners per ase, bou o vaca o porc, i 3 diners per moltó i ovella. La concessió del Consell, de l'any 1355, fou confirmada l'any 1382 per l'infant primogènit Joan, després Joan I $\mathrm{i}$, més tard, l'any 1418, pel rei Alfons el Magnànim ${ }^{296}$.

També hem trobat notícies d'algunes deveses a la comarca d'Albarrasí. El bisbe de Sogorb i Albarrasí n'aconseguí una, l'any 1257, d'Alvaro Pérez de Azagra, senyor d'Albarrasí, com a devesa de truites de riu, de conills i d'herba, és a dir, que ningú no hi podia caçar ni pasturar-hi els ramats; curiosament no hi és feta menció de la llenya ni de la fusta, de manera que és possible que fos situada en terres ermes, però no pas boscoses. Els límits indicats són del molí del Covo o de la Cueva, el riu salat de Tramacastilla i Argalla. L'any 1303 Jaume II confirmà aquesta concessió que, segons el bisbe de Sogorb, no era respectada des de l'inici de la guerra amb Caste$11 a^{297}$.

Javaloyas, una de les aldees d'Albarrasí, obtingué la concessió de devesa de l'infant Ferran, germanastre de Pere el Cerimoniós i senyor d'Albarrasí, l'any 1346. Els encarregats de fixar-ne els límits foren l'alcaid i el batlle d'Albarrasí. L'any 1377 demanaren la confirmació de la concessió a Pere el Cerimoniós ${ }^{298}$.

Una de les aldees d'Albarrasí, Ródenas, tenia devesa al mont Ombriazo, concedida en època que desconeixem, i l'any 1426 sol.licità i obtingué que fos ampliada al mont Carrascalejos, on hi havia abundància d'arbres $i$ de pastures. Alfons el Magnànim hi concedí vedat de pastures, de conills, llebres, perdius i tota altra mena de caça i prohibí que s'hi tallessin arbres: salzes, alzines, oms, etc. i llenya ${ }^{299}$.

294 ACA, C, reg. 679, f. 52 v. (1353, novembre, 28).

295 ACA, C, reg. 926 , ff. 55 v. -58 v. (1374, juny, 14).

296 ACA, C, reg. 2588 , ff. 6 v. -7 v. (1418, mars, 4$)$.

297 ACA, C, reg. 128, ff. 221 v.-222 r. (1303, juliol, 21).

298 ACA, C, reg. 930, f. 123 r.-v. (1377, març, 25).

299 ACA, C, reg. 2592 , f. 177 r. (1426, gener, 31$)$. 
Els monarques també tenien algunes deveses. Les de Signa (Singra), a una de les aldees de Daroca, «Roderca» i Pina devien ésser les més antigues; ja existien quan Saragossa rebé un privilegi de poder fer pasturar el seu bestiar a totes les terres del rei llevat d'aquelles deveses; en canvi devien ésser més modernes les d'Ansó, Hecho, Aragüés, Aïnsa, Borau, Canfranc, "Acomuel»", Tena, "Cipollera», Biescas, tinença de Gállego i "Bergueto», al Pirineu, i «Allpur»", Mosqueruela, Gúdar i Valdelinares a l'àrea de Terol, ja que els homes del rei hi demanaven herbatge i carnatge als ciutadans de Saragossa, malgrat que no figuraven entre les deveses antigues que els eren vedades ${ }^{302}$. També hi havia una devesa reial a Zuera. En teoria, els veïns de la població no hi tenien accés, però l'any 1300 el justícia del lloc, Miquel de Vayllo, els havia concedit llicències per a caçar-hi ; el munter que la guardava en protestà prop del rei perquè a causa d'aquestes llicències no havia pogut cobrar les multes corresponents als infractors de la devesa. El rei Jaume II manà, per això, al justícia que no donés més llicències ${ }^{303}$.

La Corona tenia també vedats de caça en uns territoris força extensos de la vall de l'Ebre i dels seus afluents, des de Casp a Ascó, és a dir a Aragó i al Principat. Concretament era prohibida la caça a les muntanyes de Casp, de Samper de Calanda, d'Escatrón, de Chiprana, de Flix, de Riba-roja i d'Ascó i, a més, a la regió de Sariñena i de les seves aldees: Lanaja, Robres, Grañén, Esteruelas, la Perdiguera, Peñaflor, Villamayor, Viliena, Alborge, Sena, Cajal, Candasnos, la Almolda, Ontinyena, Vilanova, Urgellet etc. L'any 1302 Jaume II concedí la munteria o guarda d'aquest vedat de caça primer a Garcia Martínez, de Casp, i pocs mesos després a Joan de Sarinyena, que era un correu seu ${ }^{304}$. Ignorem com fou solucionada aquesta coincidència en un càrrec que tenia, aparentment, la mateixa competència territorial, llevat de la comarca de Sariñena, que només apareixia en el segon nomenament. Suposem, doncs, que es resolgué dividint la competència territorial: Sariñena i les seves aldees per a Joan de Sarinyena i la resta per a Garcia Martínez, de Casp. Ambdós apareixen posteriorment exercint el càrrec l'un a la regió de Sariñena i l'altre a la de Casp. Pel novembre de l'any 1302 Joan de Sarinyena es queixà perquè un veí de Sariñena, Pere Nadal, que havia estat sorprès mentre caçava a les muntanyes del lloc, s'havia negat a pagar la multa prevista per a aquesta infracció i, a més, havia amenaçat el substitut que hi tenia, que era un veí del lloc anomenat Garcia de Tena. La resposta del rei fou ordenar que el justícia i el consell de la vila prenguessin penyores als veïns que no respectessin el vedat de caça ${ }^{305}$. Pel seu cantó, Garcia Martínez tingué dificultats primer amb el comanador de Casp, que prohibí als homes del lloc de caçar-hi i hi cobrava les multes als infractors; el rei assenyalà que això pertocava al munter ${ }^{306}$. L'any 1307 el comanador es queixà perquè els conills s'havien multiplicat i els homes de Casp es veien obligats a caçar-los. Així i

\footnotetext{
300 Potser es tracta del lloc d'Acumuer, del partit judicial de Jaca.

301 Potser es tracta del lloc d'Allepuz, una de les aldees de Terol.

302 ACA, C, reg. 116, f. 260 r.-v. (1300, novembre, 6).

303 ACA, C, reg. 116, f. 156 r. $(1300$, setembre, 20$)$.

304 ACA, C, reg. 199, ff. 87 r. i 115 v. (1302, maig, 19 i setembre, 17).

305 ACA, C, reg. 126 , ff. 143 v. (1302, novembre, 22).

306 ACA, C, reg. 203, f. 67 v. (1305, setembre, 22).
} 
tot el rei volgué que demanessin prèviament una llicència al munter per a caçar$\operatorname{los}^{307}$. L'any 1308 Jaume II es mostrava molt interessat en una devesa d'Almudévar, on hi havia vedat de cérvols, i demanà al justícia i als jurats de la vila que vigilessin que no hi anessin ballesters ni paradors de trampes perquè ell hi volia anar a ca$\operatorname{çar}^{308}$

Aquesta mena de vedats de caça no eren incompatibles amb altres usdefruits dels boscos. Ho aclarí el rei Jaume II a l'alcaid del castell d'Albarrasí, Iñigo López de Heredia, que s'havia pres massa al peu de la lletra el manament que li havia fet de reservar-li una devesa de caça $i$ havia impedit als veïns d'Albarrasí i de Cellas de tallar-hi llenya i de pasturar-hi el bestiar. Segons el monarca només havia de prohibir que s'hi cacessin cérvols o cabirols i porcs senglars amb gossos, ballestes o paranys; aquelles altres activitats hi serien permeses ${ }^{309}$.

MARIA Teresa FerRer i Mallol Institució Milà i Fontanals. CSIC

307 ACA, C, reg. 139 , f. 272 r. $(1307$, maig, 16).

308 ACA, C, reg. 140, f. 116 r. (1308, juny, 26).

309 АCA, C, reg. 134, f. 235 r. (1305, febrer, 10). 


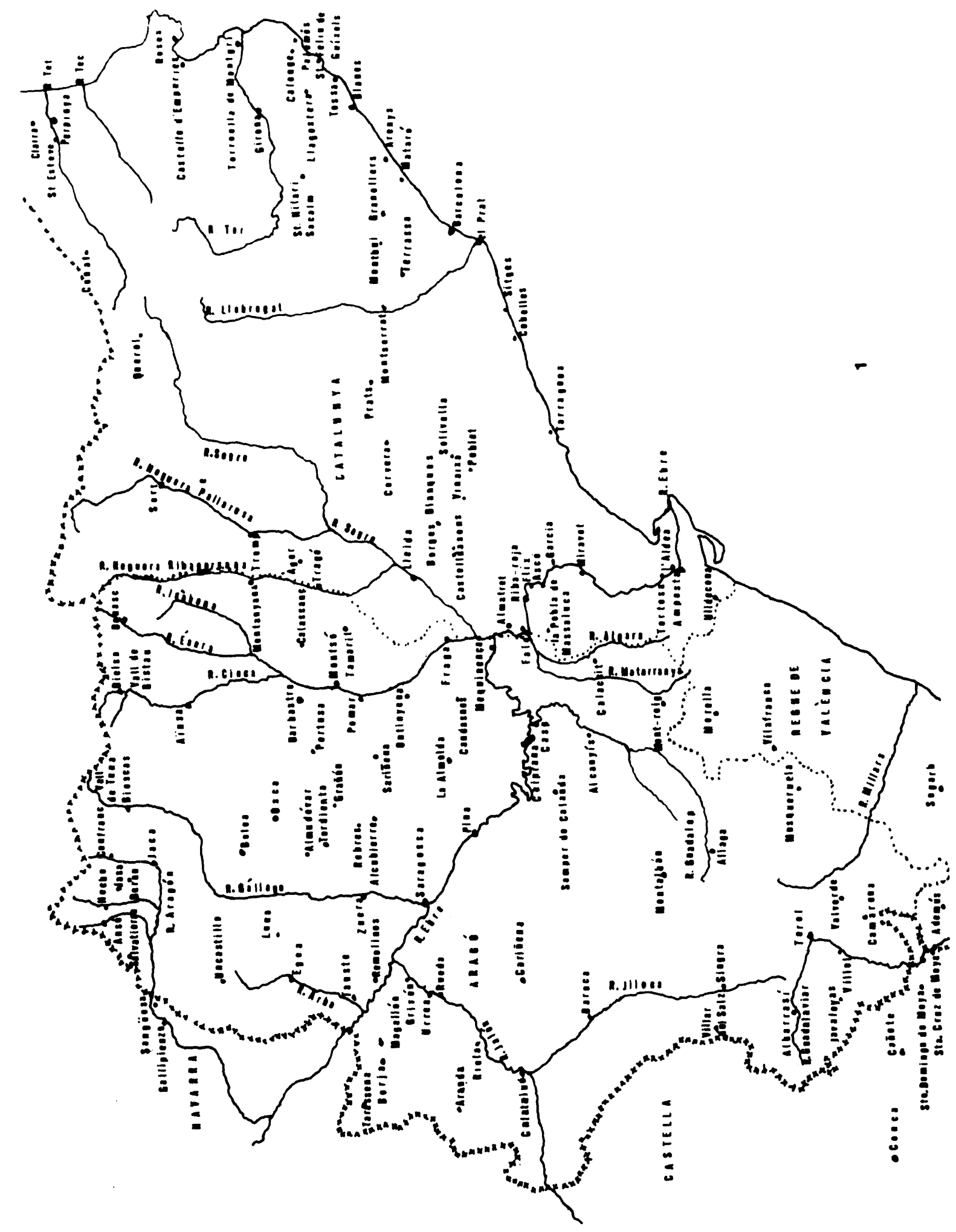




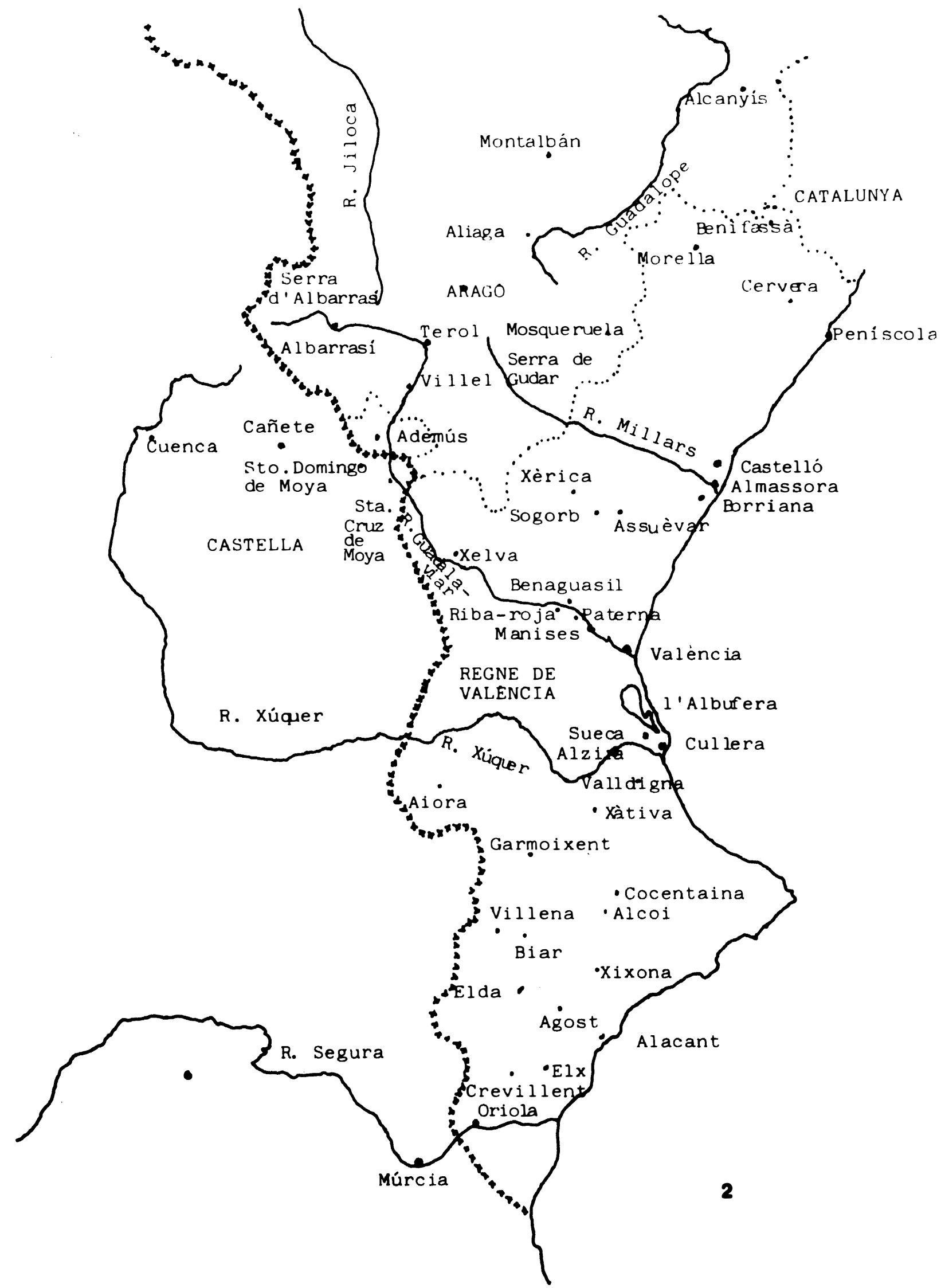

